AMERICAN UNIVERSITY WORKING PAPER SERIES

\title{
CAPITAL-SKILL COMPLEMENTARITY AND THE EMERGENCE OF LABOR EMANCIPATION
}

\author{
Boris Gershman \\ Quamrul H. Ashraf \\ Fancesco Cinnirella \\ Oded Galor \\ Erik Hornung
}

Working Paper 2017-04

http://www.american.edu/cas/economics/research/upload/2017-04.pdf

JEL No.: J24, J47,N13, N33, O14,O15, O43

AMERICAN UNIVERSITY

4400 Massachusetts Ave., N.W.,

Washington, D.C. 20016-8029

\begin{abstract}
This paper advances a novel hypothesis regarding the historical roots of labor emancipation. It argues that the decline of coercive labor institutions in the industrial phase of development has been an inevitable by-product of the intensification of capital-skill complementarity in the production process. In light of the growing significance of skilled labor for fostering the return to physical capital, elites in society were induced to relinquish their historically profitable coercion of labor in favor of employing free skilled workers, thereby incentivizing the masses to engage in broad-based human capital acquisition, without fear of losing their skill premium to expropriation. In line with the proposed hypothesis, exploiting a plausibly exogenous source of variation in early industrialization across regions of nineteenth-century Prussia, capital abundance is shown to have contributed to the subsequent intensity of de facto serf emancipation.
\end{abstract}




\title{
Capital-Skill Complementarity and the Emergence of Labor Emancipation*
}

\author{
Quamrul H. Ashraf, Francesco Cinnirella, Oded Galor, \\ Boris Gershman, and Erik Hornung ${ }^{\dagger}$
}

March 2017

\begin{abstract}
This paper advances a novel hypothesis regarding the historical roots of labor emancipation. It argues that the decline of coercive labor institutions in the industrial phase of development has been an inevitable by-product of the intensification of capital-skill complementarity in the production process. In light of the growing significance of skilled labor for fostering the return to physical capital, elites in society were induced to relinquish their historically profitable coercion of labor in favor of employing free skilled workers, thereby incentivizing the masses to engage in broad-based human capital acquisition, without fear of losing their skill premium to expropriation. In line with the proposed hypothesis, exploiting a plausibly exogenous source of variation in early industrialization across regions of nineteenth-century Prussia, capital abundance is shown to have contributed to the subsequent intensity of de facto serf emancipation.
\end{abstract}

Keywords: Labor coercion, serfdom, emancipation, industrialization, physical capital accumulation, capital-skill complementarity, demand for human capital, nineteenth-century Prussia

JEL classification codes: J24, J47, N13, N33, O14, O15, O43

${ }^{*}$ We thank Philipp Ager, Toke Aidt, Sascha Becker, Matteo Cervellati, Nicholas Crafts, Carl-Johan Dalgaard, Brad DeLong, Christian Dippel, James Fenske, Noel Johnson, Mark Koyama, Keith Kuester, James Kung, Nippe Lagerlöf, David Mitch, Steven Nafziger, Thijs van Rens, Paul Sharp, Uwe Sunde, Joachim Voth, Nico Voigtländer, Jacob Weisdorf, Niko Wolf, Ludger Wößmann, Noam Yuchtman, and seminar participants at Bonn, Caltech, Copenhagen, Higher School of Economics, HKUST, Hohenheim, HU Berlin, the Ifo Institute, Innsbruck, the Max Planck Institute for Tax Law and Public Finance, New Economic School, Passau, Southern Denmark, UC Berkeley, UCLA, Warwick, Williams, the 2015 World Economic History Congress, the 2015 CAS Workshop on Institutions, Culture, and Long-run Development, and the 2016 Summer Workshop on Economic History and Development at GMU for valuable comments. Ashraf acknowledges research support from the NSF (SES-1338738), the Hellman Fellows Program, and the Oakley Center for Humanities and Social Sciences at Williams College. Galor acknowledges research support from the NSF (SES-1338426).

${ }^{\dagger}$ Ashraf: Williams College, Department of Economics, 24 Hopkins Hall Dr., Williamstown, MA 01267, U.S.A. (email: Quamrul.H.Ashraf@williams.edu); Cinnirella: Ifo Institute for Economic Research, Center for the Economics of Education, Poschingerstr. 5, 81679 Munich, Germany (email: cinnirella@ifo.de); Galor: Brown University, Department of Economics, 64 Waterman St., Providence, RI 02912, U.S.A. (email: Oded_Galor@brown.edu); Gershman: American University, Department of Economics, 4400 Massachusetts Ave. NW, Washington, DC 20016, U.S.A. (email: boris.gershman@american.edu); Hornung: University of Bayreuth, Department of Law and Economics, Universitaetsstr. 30, 95447 Bayreuth, Germany (email: erik.hornung@uni-bayreuth.de). 


\section{Introduction}

The rise and fall of coercive labor market institutions over the course of human history has been a subject of intensive exploration across a broad range of academic disciplines. The emergence of labor coercion has generally been attributed to the increased demand for agricultural labor as well as the deepening of class stratification and the scope for domination within societies in the aftermath of the transition from hunting and gathering to agriculture during the Neolithic Revolution. In contrast, the origins of labor emancipation and the universal protection of individual property rights have been largely ascribed to sociopolitical forces in the early modern period, such as the influence of the Age of Enlightenment on the perceived value of personal freedoms or attempts by the elites in society to appease the masses in order to mitigate the adverse consequences of popular revolts. ${ }^{1}$ Nevertheless, the advent of coercive institutions following the Neolithic Revolution and their decline over the course of the Industrial Revolution suggest that the economic forces underlying these profound changes in the structure of production were also at the roots of the associated transformations in labor market institutions. In particular, while the agricultural revolution was associated with the rise of unskilled labor-intensive production, the Industrial Revolution marked a systematic transition to a skill-intensive production structure.

This paper advances a novel hypothesis regarding the historical roots of labor emancipation. It suggests that the decline of labor coercion in the industrial stage of development has been an inevitable by-product of the emergence of capital-skill complementarity in the production process. In the earlier agricultural stage of development, production was largely intensive in unskilled labor, and landowning elites had an incentive to promote and maintain coercive institutions that limited labor mobility and boosted land rents. ${ }^{2}$ Over the course of industrialization, however, the accumulation of physical capital by the landed elites coupled with the advent of capital-skill complementarity altered their viewpoint regarding the profitability of exploiting coerced labor, thus bringing an end to this oppressive institutional regime. Specifically, in light of the growing significance of skilled labor for fostering the return to physical capital, landowning capitalist elites were induced to relinquish their historically advantageous coercion of labor in favor of employing free skilled workers. These uncoordinated actions of the elites, in turn, incentivized the masses to engage in broad-based human capital acquisition, without fear of losing their skill premium to expropriation. ${ }^{3}$ The posited mechanism therefore suggests that willingness to abandon the extant

\footnotetext{
${ }^{1}$ In particular, the Age of Enlightenment is known to have triggered major institutional transformations (e.g., de jure agrarian reforms and the abolition of serfdom) throughout regions of Europe that were occupied by Napoleon's French Revolutionary Army, paving the way for subsequent economic development (Acemoglu et al., 2011; Buggle, 2016).

${ }^{2}$ It is generally agreed, however, that because feudal relations prevented labor from being allocated efficiently, the process of society-wide economic development was held back in regions characterized by coercive institutions (North and Thomas, 1973; Brenner, 1976; Acemoglu and Robinson, 2012).

${ }^{3}$ The role of alternative economic forces in the emergence of labor emancipation has been explored by Lagerlöf (2009). In his theory, the elites choose between imposing serfdom and freedom in order to maximize their payoffs, as determined by population density and the level of technology.
} 
regime of labor coercion was more pronounced amongst elites whose stakes in the ownership of physical capital were larger in early stages of industrialization. ${ }^{4}$

The proposed hypothesis is examined empirically by exploiting both cross-sectional and temporal variations in de facto serf emancipation in nineteenth-century Prussia. Although serfdom was de jure abolished throughout Prussia in 1807, the process of de facto emancipation from coercive institutions evolved heterogeneously across regions, extending well into the second half of the nineteenth century. In particular, at the individual level, the termination of feudal labor relations was the outcome of a bilateral negotiation regarding the compensation owed to the manorial landlord for the redemption of lifetime servile duties by the serf, thus introducing sufficient scope for variation in the duration of the de facto emancipation process. ${ }^{5}$ The empirical analysis therefore links the differential timing of de facto emancipation with variation in the initial extent of proto-industrialization across regions of Prussia.

Exploiting unique data on emancipation cases, originally collected and reported at the county level by the Prussian state agency that supervised these settlements, the analysis finds a positive and significant relationship across counties between the initial stock of physical capital per capita, as proxied by the prevalence of water mills in 1819, and the share of serfs that were de facto emancipated between 1821 and 1848. ${ }^{6}$ This relationship proves to be remarkably robust to accounting for a wide range of potentially confounding factors, including observed heterogeneity across regions in geographical, cultural, and institutional characteristics and in various dimensions of historical development.

The analysis implements two alternative strategies to mitigate potential concerns regarding endogeneity in the relationship between early industrialization and the subsequent intensity of $d e$ facto serf emancipation. The first strategy, implemented in the baseline cross-sectional setting, exploits terrain slope as a plausibly exogenous source of variation in the prevalence of water mills across counties in 1819, conditional on a sizable vector of other geographical factors. This strategy yields 2SLS estimates for the influence of the initial stock of physical capital that are quantitatively similar to the baseline OLS estimates, suggesting that the latter are not marred by any substantial

\footnotetext{
${ }^{4}$ In contrast to the notion that average worker skills were generally unimportant until later stages of industrialization, Franck and Galor (2017) uncover new evidence linking early industrialization with the rise in the demand for human capital in mid-nineteenth-century France, consistent with an earlier emergence of technology-skill complementarity. Moreover, Squicciarini and Voigtländer (2015) show that although the density of "upper tail" human capital, as proxied by the prevalence of knowledge elites, was instrumental for productivity growth (innovation) and urbanization during the first phase of the French Industrial Revolution, average worker skills, as proxied by literacy rates, were nevertheless important for the level of productivity under the existing technologies, in accordance with the complementarity of average skills in industrial production. Further, in the context of nineteenth-century Prussia, Becker et al. (2011) document that basic education was significantly associated with industrialization in its early stages. Similarly, Cinnirella and Streb (forthcoming) find that literacy rates were positively related to productivity during the second phase of Prussian industrialization.

${ }^{5}$ In addition, state supervision provided a commitment device for both serfs and their manorial landlords to honor the redemption agreement (Ogilvie, 2014).

${ }^{6}$ As will become evident, for the purposes of empirically examining the proposed hypothesis, water mills are particularly suitable as a proxy measure of early industrialization, first, because their ownership was institutionally restricted to the landed elites, and second, because they foreshadowed the adoption of steam engines and related skill-intensive methods of industrial production.
} 
amount of endogeneity bias, given the identifying assumption regarding the conditional excludability of terrain slope. The second strategy exploits time-varying district-level data on the number of settled redemption cases during the latter half of the nineteenth century, implementing a flexible panel setting in which the initial stock of physical capital is permitted to possess a time-varying relationship with the average annual flow of de facto emancipated serfs in different five-year periods. This strategy is able to account for unobserved heterogeneity across districts in time-invariant geographical, cultural, and institutional characteristics, in addition to the time-varying influence of sociopolitical and demographic observables at the district level as well as region-specific time trends in emancipation flows at higher levels of spatial aggregation.

The empirical analysis also explores the extent to which the main findings may reflect alternative theories of the historical decline in coercive labor institutions. ${ }^{7}$ For instance, one class of theories emphasizes that coercion can decline either with an increase in labor abundance, due to the resulting depression in market wages, or when an increase in outside options for workers poses the threat of labor scarcity (Postan, 1966; Domar, 1970; Brenner, 1976; Acemoglu and Wolitzky, 2011). ${ }^{8}$ Another alternative explanation is that the elites strategically relinquished political (and coercive economic) power over the masses in order to avert social unrest (Acemoglu and Robinson, 2000; Aidt and Franck, 2015). The analysis accounts for these particular alternative mechanisms by introducing controls for labor abundance and the prevalence of social uprisings. More generally, although these and other alternative theories are found to possess some explanatory power for the decline of serfdom in Prussia, the proposed hypothesis continues to explain a significant portion of the variation in the timing of de facto serf emancipation.

Furthermore, the empirical analysis provides additional corroborating evidence lending credence to the proposed interpretation of the positive reduced-form relationship between the initial stock of physical capital and the intensity of de facto serf emancipation by the mid-nineteenth century. First, exploiting heterogeneity across counties in the average cost of redemption per emancipation case (i.e., the negotiated emancipation "price" between the manorial landlord and the serf), the analysis finds that the prevalence of water mills in 1819 is negatively associated with the average cost of redemption per emancipation case as of 1848. This result is in accordance with the notion that landlords with larger stakes in the ownership of physical capital were more willing to accept lower redemption costs and, thus, hasten the process of serf emancipation. Second, consistent with an indirect outcome of the proposed hypothesis, the rate of serf emancipation as

\footnotetext{
${ }^{7}$ See Ogilvie and Carus (2014) for an overview of alternative explanations.

${ }^{8}$ More recently, Naidu and Yuchtman (2013) and Dippel et al. (2015) provide evidence that potential labor scarcity due to superior outside options for workers may have triggered the decline of coercive institutions in different historical contexts. An empirical exploration of this mechanism across societies in a global sample is conducted by Fenske (2013). At a conceptual level, the threat of outside options for workers becomes binding for the abolition of coercive institutions when the concentration of economic resources in the hands of the elites - i.e., resources that could be used to counter such a threat - is either stagnant or declining. In contrast, the proposed hypothesis suggests that the abolition of coercive institutions can occur when the concentration of economic resources among the elites is, in fact, increasing over time, due to market rents associated with the accumulation of physical capital. As such, the prevalence of the alternative mechanism associated with labor scarcity only serves to introduce downward bias to the estimates associated with the proposed mechanism.
} 
of 1848 is shown to be positively associated with the subsequent rate of human capital accumulation, as reflected by either the enrollment rate in public primary schools in 1864 or the literacy rate amongst the population aged 10 and above in $1871 .{ }^{9}$ Moreover, in line with the historical narrative of the Prussian labor emancipation experience, the analysis provides prima facie empirical evidence that labor markets were highly segmented across Prussian counties in the early nineteenth century, suggesting that the de facto serf emancipation process primarily reflected local labor market conditions. Specifically, the presence of relatively autarkic market conditions at the county level makes the observed variations across Prussian counties in early industrialization and subsequent emancipation and human capital formation suitable for empirically examining the proposed hypothesis. ${ }^{10}$

This paper contributes to both sides of the broader debate on the causes of institutional change in societies. On the one hand, the proposed hypothesis advances modernization theory (Lipset, 1959; Barro, 1999, 2015; Glaeser et al., 2004, 2007), highlighting structural economic transformation, particularly the rise in the importance of human capital in the process of development, as a catalyst of institutional change. On the other hand, in light of the fact that the "defensive modernization" of Prussia, comprising the de jure agrarian and emancipation reforms of the early nineteenth century, occurred partly as a response to the threat from the militaristic diffusion of the ideas of the French Revolution, the empirical findings highlight modernization as a driver of de facto changes in local institutions, following the "critical juncture" (Acemoglu and Robinson, 2012) of a de jure change in centralized state institutions.

The emphasis of the proposed hypothesis on capital-skill complementarity and the increased demand for human capital in the process of industrialization relates with previous studies that have highlighted the importance of this phenomenon for understanding the emergence of support for universal public schooling by the elites (Galor and Moav, 2006; Galor et al., 2009). In contrast to these contributions, this paper advances the fundamental insight that, by itself, the provision of universal public education by the elites is insufficient to guarantee investments in human capital by the masses, particularly when the skill premium may be subject to expropriation under coercive institutions. ${ }^{11}$ Thus, the abolition of coercive institutions by the elites represents a necessary precondition for efficient investments in human capital.

Although the focus of this paper is on the causes of labor emancipation, it contributes to an emerging literature devoted to the long-run consequences of coercive labor institutions. Cinnirella

\footnotetext{
${ }^{9}$ It is crucial to note, however, that the proposed hypothesis employs a broad interpretation of investments in human capital, reflecting any private effort undertaken to increase effective labor, encompassing skill acquisition through not just formal education but also occupational training and experience, as well as improvements in health.

${ }^{10}$ In addition, the proposed hypothesis suggests that the elites within a given county did not need to solve a collective action problem, in terms of coordinating on the timing of emancipation of their respective serfs. In particular, according to the posited mechanism, there is no ex post threat of labor scarcity to a member of the elite from freeing his serfs, because the complementarity between free workers and the elite's physical capital ensures that, upon being rehired as free workers, his former serfs would earn wage rates that are at least as high as any local outside option.

${ }^{11}$ Furthermore, because educational investments require private effort that is costly to monitor, compulsory schooling in the presence of expropriation would not ensure the first-best outcome, in terms of the effort exerted by the masses towards the accumulation of human capital.
} 
and Hornung (2016a) provide supporting evidence that serf emancipation was indeed related to subsequent increases in formal schooling in the Prussian context. ${ }^{12}$ Similarly, McElroy (2015) finds that local variation in serf obligations shaped post-emancipation patterns of human capital accumulation in Russia. Markevich and Zhuravskaya (2015) document that serf emancipation was related to subsequent increases in agricultural productivity in nineteenth-century Russia. Relatedly, Nafziger (2012) presents evidence that the abolition of serfdom also affected non-farming activities undertaken by former serfs in the Russian context, whereas Buggle and Nafziger (2015) examine the long-run consequences of the intensity of labor coercion for present-day comparative development across post-Soviet regions. Finally, Acemoglu et al. (2011) document that institutional reforms, including the de jure abolition of serfdom, that arose from the diffusion of the French Revolution into European regions occupied by the French are associated with differential patterns of long-run economic development across German polities.

The remainder of the paper is structured as follows. Section 2 provides a basic formalization of the proposed hypothesis. Section 3 discusses the historical and institutional background relevant for the labor emancipation and proto-industrialization experiences in the Prussian context. Section 4 introduces the unique administrative data on de facto serf emancipation that is exploited by the empirical analysis, along with the main explanatory variable and various geographical and historical covariates. Section 5 reveals and discusses the empirical findings, and finally, Section 6 concludes.

\section{Conceptual framework}

In this section, we present a basic model that highlights our novel mechanism underlying the emancipation of labor. Specifically, the model demonstrates how the accumulation of physical capital raises the demand for human capital due to the complementarity between these factors in the production process, thereby incentivizing landowning capitalist elites to grant economic freedom to laborers, in order to encourage the latter to undertake costly investments in relevant skills. The purpose of our model is to narrowly focus on this particular channel, emphasizing the role of early industrialization in driving the abolition of serfdom. We therefore intentionally abstract from a variety of complementary theories of the evolution of coercive labor institutions that have been examined previously in the literature. We also discuss how our model can be integrated into a richer (and, admittedly, more realistic) framework without altering the fundamental insight.

\section{$2.1 \quad$ The basic model}

Consider a society comprising two classes of individuals: landowning capitalists (elites) and coerced laborers (serfs). Their respective population shares are $\lambda \in(0,1)$ and $1-\lambda$. Rather than drawing an explicit distinction between landowners and capitalists as in Galor et al. (2009), we portray the

\footnotetext{
${ }^{12}$ A related literature (e.g., Sacerdote, 2005; Bertocchi and Dimico, 2014; Bobonis and Morrow, 2014) has explored the relationship between slavery in the Americas and the accumulation of human capital.
} 
elites as a single class. The elites in our model may be viewed as the landowners from Galor et al. (2009) that have already gained a large enough stake in the ownership of capital - an outcome that occurs inevitably in the process of economic development. As explained in Section 3.3 below, our modeling choice is also consistent with the historical reality of nineteenth-century Prussia, where landowners were amongst the most active early capitalists, establishing industrial methods of production on their own estates. For simplicity, we assume that the initial economy-wide capital stock, $K_{0}$, is uniformly distributed amongst the elites. Assuming additionally a uniform distribution in (implicit) landownership rules out the conflict of interest within the class of elites in our model.

The economy lasts for two periods. At the beginning of the first period, the elites - who hold all the political power in this economy - decide on the status of the laborers; namely, whether they should be coerced or granted economic freedom in the second period. We assume that the elites can credibly commit to enforcing such a decision by enacting the legislation sufficient for the abolition of serfdom. ${ }^{13}$ After learning about their status, the laborers decide whether to undertake costly investment in their human capital. Production occurs in the second period, in which the laborers and the elites inelastically supply human and physical capital, respectively.

Output, $Y$, is produced according to a standard Cobb-Douglas production function, using physical and human capital, $K$ and $H$, as inputs:

$$
Y=A H^{1-\alpha} K^{\alpha}, \quad \alpha \in(0,1),
$$

where $A$ is the index of technological advancement, or total factor productivity (TFP). Since the objective of our basic model is to distill the role of industrialization in transforming coercive labor institutions, we abstract away from explicitly including land as factor of production, thus focusing squarely on the key complementarity between physical and human capital in the production process. As mentioned earlier, we consider capital-owning elites that are deciding for or against employing serf labor in industrial or proto-industrial production, rather than in agriculture. It is also worth noting that we adopt a broad definition of human capital that goes beyond just formal schooling, including occupational skills that require costly effort and learning to acquire, as well as worker characteristics that contribute to labor productivity such as better health. Thus, the stock of human capital in our model economy may be viewed as the supply of effective rather than raw labor.

In the state of the world with freed labor, factors earn their marginal products, i.e.,

$$
r=\alpha A k^{\alpha-1}, \quad w=(1-\alpha) A k^{\alpha}, \quad k \equiv K / H,
$$

\footnotetext{
${ }^{13}$ According to Ogilvie and Carus (2014), the economic history of Prussian serfdom provides "arguably the best example" of how the state was instrumental for solving the credible commitment problem, by devising and enacting a clear set of rules for serf emancipation. Unlike our framework, however, these authors view the abolition of serfdom as a zero-sum event wherein the serfs were the only winners from the emancipation reforms. As such, to ensure that the reforms would not be blocked by the losing elites, the commitment of the reforms to adequately compensate the landlords was effectively enforced by the accompanying legislation.
} 
where $r$ and $w$ are, respectively, the rate of return to physical capital and the wage rate under perfectly competitive factor markets in this economy. ${ }^{14}$ Under serfdom, the rich appropriate all of the output after providing a "subsistence" level of consumption, $\tilde{c}$, to each laborer.

At the beginning of the first period, should the elites decide to maintain serfdom, the laborers will not have any incentive to undertake the costly acquisition of human capital, because in the second period, they would invariably receive only $\tilde{c}$. In addition, we assume that the elites cannot effectively force their serfs to acquire human capital and/or supply it without moral hazard to the production process. The underlying argument here is that it is much more difficult to monitor both the acquisition and the application of skills, in comparison to the monitoring of raw labor. In contrast to simple agricultural production, the effort, attentiveness, and quality of workers in skill-intensive production are observed much more noisily, thus making both monitoring compliance and the setting of output targets exceedingly costly and ineffective. ${ }^{15}$ We consider an extreme case in which the extraction of skills by force is completely infeasible and/or the costs of effectively monitoring the application of skills are prohibitively high. As such, the laborers will only consider investing in human capital if they are granted the economic freedom to secure the perfectly competitive rate of return from that investment. Specifically, under freedom they choose their effort level, $e$, in order to maximize the following utility function:

$$
w h(e)-v(e)=w(1+e)^{\phi}-e,
$$

where $w$ is the perfectly competitive wage rate in the second period; $h(e)=(1+e)^{\phi}, \phi \in(0,1)$, is the human capital production function, which is increasing and concave in the amount of effort, $e$; and $v(e)=e$ is the disutility of this effort. Further, $h(0)=1$, so each laborer is endowed with a basic unit of human capital (raw labor) to be supplied in the second period. Utility maximization by a laborer then yields the following optimal level of effort under freedom:

$$
e^{*}=\max \left\{(\phi w)^{\frac{1}{1-\phi}}-1,0\right\}=\max \left\{\left(\phi(1-\alpha) A k^{\alpha}\right)^{\frac{1}{1-\phi}}-1,0\right\} .
$$

It therefore follows that under serfdom, the total stock of human capital (raw labor) is equal to $(1-\lambda) h(0)=(1-\lambda)$, whereas under freedom, it is $(1-\lambda) h\left(e^{*}\right)=(1-\lambda)\left(1+e^{*}\right)^{\phi}$. For simplicity, we assume that the elites do not participate in the labor market, so they depend entirely on their capital rents.

\footnotetext{
${ }^{14}$ For simplicity, we assume that physical capital depreciates fully in each period, so that the gross and net returns to physical capital are identical.

${ }^{15}$ This argument goes back at least to Fenoaltea (1984), who considered the relative effectiveness of pain incentives and monitoring in land- or labor-intensive versus capital- or "care-intensive" production. As he points out, "human capital - the exercise of skill - is particularly subject to covert sabotage," and in the limit, it can take "the full time of one skilled supervisor to monitor one skilled worker" (pp. 639-640). As a result, increasing the complexity and skill-intensiveness of the production process lowers the effectiveness of pain incentives and raises the cost of administering them. A related argument has been made by Millward (1984), who in rationalizing the adoption of serf-labor quitrent systems amongst the serfowning nobility in Eastern Europe, asserts that "[t]he more uncertain the production venture and the smaller was the scope for scale economies in supervising groups of serfs the more profitable was it for the noble to avoid setting predetermined performance levels and to give the serf economic incentives to raise output" (p. 425).
} 
At the beginning of the first period, the capitalists make their decision regarding the status of the laborers, passing the corresponding legislation if they choose to abolish serfdom. The elites make this choice in order to maximize their second-period income. Under freedom, this income is simply $r K_{0}$, the total competitive-market return to physical capital, whereas under serfdom, it is $Y-(1-\lambda) \tilde{c}$, the total output of the economy after providing for the subsistence consumption of all the laborers.

Should the laborers find it optimal to invest a positive amount of effort in human capital acquisition under freedom (i.e., when $e^{*}>0$ ), the equilibrium level of capital per effective worker, $k$, would be given by

$$
k=\frac{K}{H}=\frac{K_{0}}{(1-\lambda)\left(\phi(1-\alpha) A k^{\alpha}\right)^{\frac{\phi}{1-\phi}}} \Longrightarrow \quad k=\left(\frac{K_{0}}{1-\lambda}\right)^{\frac{1-\phi}{1-\phi(1-\alpha)}} \cdot(\phi(1-\alpha) A)^{\frac{\phi}{\phi(1-\alpha)-1}} .
$$

Alternatively, under serfdom, or if $e^{*}=0$ under freedom, then $k=K_{0} /(1-\lambda)$. Along with the function for the optimal level of effort, this implies that the laborers will invest a positive amount of effort in human capital acquisition if and only if they are free and the following condition holds:

$$
\kappa \equiv\left(\frac{K_{0}}{1-\lambda}\right)^{\alpha}>\frac{1}{\phi(1-\alpha) A} \equiv \hat{\kappa}
$$

In other words, investment in human capital is more attractive to freed laborers when the perfectly competitive wage rate is high - i.e., when the stock of complementary physical capital is large and/or the economy's technological level is more advanced.

In the second period, under freedom, the income of the elites is given by $r K_{0}=\alpha A k^{\alpha-1} K_{0}$, and it is strictly increasing in the stock of human capital acquired by the laborers, as the latter augments the rate of return to physical capital due to the complementarity between the two factors in the production process. Under serfdom, however, since $K=K_{0}$ and $H=1-\lambda$, the secondperiod income of the elites is equal to $A(1-\lambda)^{1-\alpha} K_{0}^{\alpha}-(1-\lambda) \tilde{c}$. In order to realistically model the process of labor emancipation, we only consider the range of $K_{0}$ values for which serfdom is initially profitable for the elites, in the sense that the marginal product of labor is sufficiently large to cover the level of subsistence consumption per worker:

$$
(1-\alpha) A\left(\frac{K_{0}}{1-\lambda}\right)^{\alpha}>\tilde{c} \quad \Longleftrightarrow \quad \kappa>\frac{\tilde{c}}{(1-\alpha) A} \equiv \bar{\kappa}
$$

Otherwise, it would be too costly for the elites to meet the subsistence consumption requirement of the laborers, thereby making the elites unconditionally better off by immediately granting freedom to the laborers, even if no effort will be made to acquire human capital. Therefore, to ensure the historical presence of serfdom prior to the advent of emancipation reforms, we assume that (A1) holds, which then implies that enacting emancipation reforms would not be optimal for the elites if the freed workers do not end up investing a positive amount of effort in the acquisition of human 


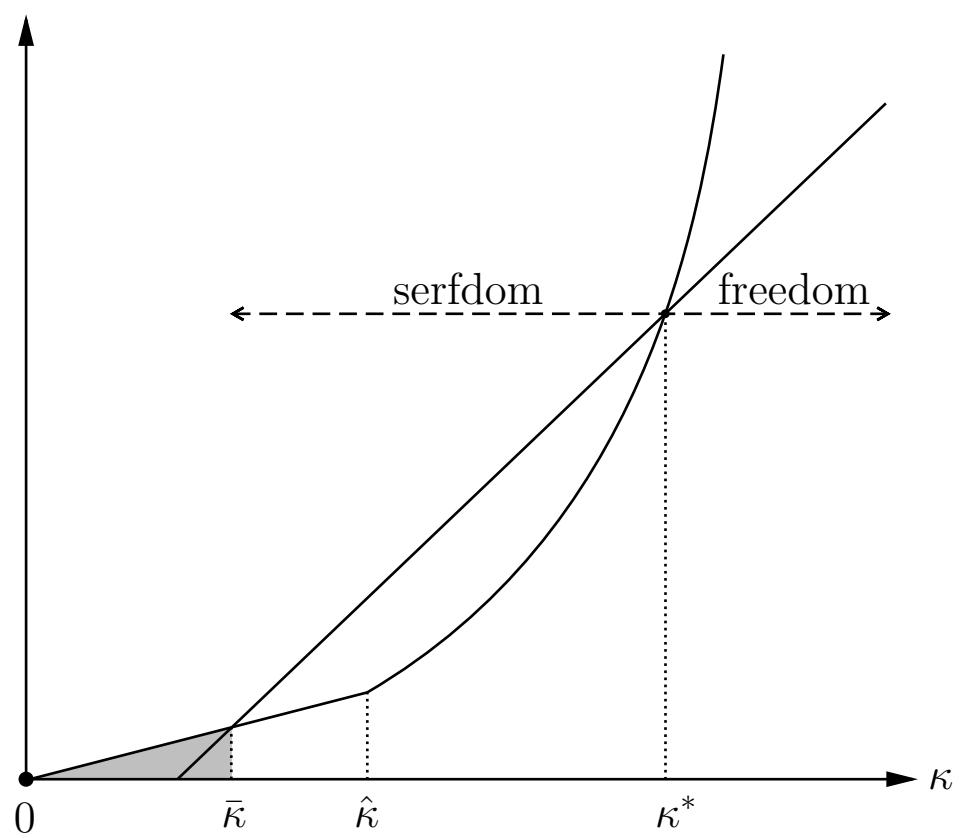

Figure 1: Physical capital and labor emancipation

Notes. This figure graphically depicts how the second-period income of the elites compares under serfdom versus freedom of the laborers for different values of $\kappa \equiv\left(K_{0} /(1-\lambda)\right)^{\alpha}$, which is an increasing function of the initial stock of physical capital per unit of raw labor. For $\kappa<\bar{\kappa}$, serfdom is never profitable for the elites, so this region is disregarded. For $\kappa \in\left[\bar{\kappa}, \kappa^{*}\right]$, maintaining serfdom is more profitable than granting freedom, even though for $\kappa>\hat{\kappa}$, the laborers would actually invest in human capital if freed. Finally, for $\kappa>\kappa^{*}$, freedom is more profitable for the elites than serfdom.

capital. ${ }^{16}$ In addition, we assume that $\bar{\kappa}<\hat{\kappa}$, which holds if and only if

$$
\phi \tilde{c}<1
$$

This ensures that for small enough levels of $K_{0}$ satisfying (A1), the laborers would not invest in human capital under freedom, so maintaining serfdom in the second period is more profitable from the viewpoint of the capitalists.

The elites will choose to abolish serfdom if and only if their second-period income under freedom exceeds that under serfdom; i.e., if and only if

$$
r K_{0}=\alpha A\left(\frac{K_{0}}{1-\lambda}\right)^{\frac{(1-\phi)(\alpha-1)}{1-\phi(1-\alpha)}} \cdot(\phi(1-\alpha) A)^{\frac{\phi(\alpha-1)}{\phi(1-\alpha)-1}} \cdot K_{0}>A(1-\lambda)^{1-\alpha} K_{0}^{\alpha}-(1-\lambda) \tilde{c}
$$

which upon rearrangement yields

$$
\alpha A \kappa^{\frac{1}{1-\gamma}} \cdot(\gamma A)^{\frac{\gamma}{1-\gamma}}>A \kappa-\tilde{c}, \quad \gamma \equiv \phi(1-\alpha) \in(0,1) .
$$

\footnotetext{
${ }^{16}$ Clearly, (A1) also implies that the laborers are unconditionally better off under freedom, while a violation of (A1) implies that free laborers would rather be enserfed and provided a subsistence level $\tilde{c}$ by the elites.
} 
Under assumptions (A1) and (A2), there exists a unique level of $\kappa, \kappa^{*}$, such that labor emancipation occurs if and only if $\kappa>\kappa^{*}$, as shown in Figure 1. It follows immediately that there exists a unique level of capital per unit of raw labor, $k_{0}^{*}=K_{0}^{*} /(1-\lambda)=\left(\kappa^{*}\right)^{1 / \alpha}$, such that labor emancipation occurs if and only if $k_{0}>k_{0}^{*}$. It is also worth noting that the profitability of serfdom from the viewpoint of the elites clearly increases in $K_{0}$, given that subsistence consumption per worker is fixed. Nevertheless, due to the boost in the acquisition of human capital by the laborers under freedom, the profitability of freedom rises even more strongly, ultimately making it incentive compatible for the elites to abolish serfdom. In sum, our basic model suggests that, all else equal, a larger stock of physical capital per worker contributes to the process of labor emancipation. As such, the extent of early industrialization is expected to be positively associated, ceteris paribus, with the subsequent rate of labor emancipation.

\subsection{Extensions of the framework}

Our basic model can be extended along several dimensions to incorporate a more realistic set of assumptions without qualitatively altering the key insight. First, although in the interest of clarity, we opted to present our main argument in a two-period setting, our model can be seamlessly integrated into a standard overlapping-generations framework à la Galor and Moav (2004, 2006) or Galor et al. (2009), incorporating endogenous physical capital accumulation. In such a dynamic model, capital accumulation would be driven by either the bequest or the standard saving motive, and the choice between the preservation and the abolition of serfdom would be made by each generation of the elites. Prior to the emancipation of labor, the growth process would be driven purely by the accumulation of physical capital by the elites, but following emancipation, the former serfs would also contribute to this process, initially through their accumulation of human capital alone and eventually through their accumulation of physical capital as well (see, e.g., Galor and Moav, 2006). The value added of such a dynamic framework is that by making the process of physical capital accumulation more explicit, it would demonstrate more evidently that the abolition of serfdom occurs as a natural by-product of the process of economic development. Relatedly, technological progress in such a model, as reflected by a gradual rise in the level of productivity, $A$, would produce a similar effect as physical capital accumulation, because in light of technology-skill complementarity, TFP growth will not only raise the elites' demand for mass investments in human capital but also encourage skill acquisition by the freed laborers.

Second, relaxing the simplifying assumption that the elites do not participate in the labor market and, thus, do not engage in human capital accumulation would have the following implications. Naturally, the elites would initially invest in their own human capital when the rate of return from this investment becomes sufficiently high - i.e., when there is a large enough stock of physical capital. Although this process is likely to delay the emancipation of the class of coerced laborers, diminishing returns to human capital accumulation at the individual level will ensure that, sooner or later, continued skill formation by the elite minority will cease to support a high rate of return to physical capital. Thus, akin to our basic model, the anticipated expansion in economy-wide human 
capital generated by large-scale skill acquisition on part of the freed laborers would eventually make it incentive-compatible for the elites to abolish serfdom. ${ }^{17}$

Third, although our basic model assumes that the acquisition of human capital by the freed laborers does not involve any fixed cost in terms of output (or the consumption good), relaxing this assumption and even introducing the more realistic feature of credit market imperfections (e.g., Galor and Zeira, 1993; Galor and Moav, 2004, 2006; Galor et al., 2009) would again merely serve to delay the abolition of serfdom by the elites. In particular, under binding constraints on the ability of the former serfs to obtain credit, the elites would have to tax themselves in order to finance the real cost associated with the acquisition of human capital by the masses (e.g., through public schooling), and as such, the profitability of granting freedom from the viewpoint of the elites would become conditioned by the amount of this fixed tax burden. Nevertheless, once the elites' demand for mass acquisition of human capital becomes sufficiently high due to a large enough stock of physical capital, they will find it incentive-compatible to financially support large-scale emancipation and the concomitant acquisition of human capital by the freed laborers, as the profitability of granting freedom net of the fixed tax burden inevitably rises above the profitability of maintaining serfdom.

Fourth, as discussed earlier, our basic model abstracts from the potential conflict of interest between landowners and capitalists in the decision to maintain or abolish serfdom, choosing instead to treat the elites as a single class of "landowning capitalists" with equal stakes in the economy's assets. The implications of relaxing this assumption, however, can be readily inferred from the findings of Galor et al. (2009), who examine the role of landownership inequality in delaying the emergence of human-capital promoting institutions, such as public schooling. A central feature of their argument is that human capital is less complementary to land than it is to physical capital and, therefore, as long as their stake in industrial production is small, the landed aristocracy has little economic incentive to financially support the advent of universal education, which would not only require taxing themselves explicitly but would also divert workers away from the agricultural sector, thereby raising wages and lowering the return to land. Therefore, to the extent that the landowners affect the political process, this consideration would impede the introduction of public schooling. For precisely the same rationale, if our basic model were extended to incorporate the two-sector structure of Galor et al. (2009), the abolition of serfdom would, yet again, be merely delayed by the presence of politically influential landowning elites, at least until their stakes in industrial production become sufficiently large so as to align their economic interests with those of the capitalist elites. ${ }^{18}$

\footnotetext{
${ }^{17}$ It may be noted that in such an extension of the model, wherein the elites are allowed to engage in human capital accumulation, the decision to maintain or abolish serfdom will be conditioned by a secondary effect of emancipation on the profitability of freedom from the viewpoint of the elites. Namely, the subsequent increase in the economy-wide supply of human capital will tend to depress the wage income of the elites, thereby serving to delay their support of large-scale emancipation reforms. Because this general equilibrium effect simply obfuscates our main mechanism and unnecessarily complicates the analysis, we choose to model the elites as a purely rentier class.

${ }^{18}$ We relax our theoretical assumption in our empirical analysis, where we account for the potential role of "conservative" landowners by including a measure of concentration in land ownership in our estimating equation.
} 
Overall, our fundamental insight regarding the influence of physical capital accumulation by the elites in society on their decision to support large-scale labor emancipation remains qualitatively unchallenged by these additional considerations.

\section{Historical background}

\subsection{Agrarian reforms, de facto emancipation, and elite class structure}

The Prussian agrarian (Stein-Hardenberg) reforms of the early nineteenth century provide a historical setting that is particularly well-suited for empirically examining our hypothesis regarding the role of industrialization and capital ownership by the elites in driving the subsequent decline in coercive labor institutions. In what follows, we briefly discuss some of these key reforms and how they served to generate rich heterogeneity in the pace and extent of de facto labor emancipation across regions of Prussia over the course of the nineteenth century. ${ }^{19}$ We also discuss how these reforms served to shift the composition of the class of rural elites to incorporate landed manorial entrepreneurs with bourgeois orientations towards industrial production methods. To be clear, we view these outcomes of the reforms as important for producing the variation necessary for the falsification of our hypothesis. ${ }^{20}$

As of the late eighteenth century, peasant labor coercion associated with feudal political authority had been practiced for centuries by Prussian Junkers (the landed aristocracy) at varying levels of intensity throughout the Kingdom of Prussia (see, e.g., Ogilvie and Carus, 2014). A marked change in de jure institutions, however, occurred in the early nineteenth century, following the defeat of Frederick William III of Prussia by Napoleon's forces at the Battle of Jena-Auerstedt in 1806 and the ensuing Second Treaty of Tilsit, in which Prussia ceded about half of its territories and was forced to make substantial tribute payments to France. This adverse shock to the political economy of the region triggered the so-called "defensive modernization" of Prussia, based on Frederick William III's position that the Prussian state and Prussian society could not survive unless

\footnotetext{
${ }^{19}$ Appendix C provides some additional details, summarizing the heterogeneity in the de jure emancipation process across different categories of the enserfed peasant population, both in the Prussian territories that were not ceded to France in the Second Treaty of Tilsit (1807) as well as in those territories that were annexed or regained by Prussia following the Congress of Vienna (1815).

${ }^{20}$ Our hypothesis is broadly consistent with various elements of the Prussian historical narrative regarding emancipation and industrialization. For instance, Pierenkemper and Tilly (2004) have described the Prussian peasant emancipation process (Bauernbefreiung) as a prerequisite for the widespread adoption of industry, arguing that labor productivity increased over the course of the reform period. Nevertheless, the historical literature on peasant emancipation in Prussia has generally tended to focus either on the redistribution of resources from peasants to the nobility (e.g., Schissler, 1978; Dipper, 1980; Harnisch, 1984; Pierenkemper, 1989) - i.e., as a result of the compensation payments from the former to the latter for the commutation or redemption of labor dues - or on the economic conditions of those peasants who remained attached to agriculture following their emancipation (e.g., Knapp, 1887; Böhme, 1902; Berthold, 1978). Ignoring the emancipation-oriented incentives associated with the emergence of capital-ownership amongst the landed nobility, this literature has tended to highlight other complementary forces underlying the nobility's rationale to ultimately agree to the emancipation reforms, including changing market conditions in agricultural free-labor and goods markets, the temporary decline in political power amongst the nobility in the aftermath of Prussia's defeat by Napoleon in 1806, and the allocation of compensation payments to overcome debts associated with noble estates.
} 
progressive reforms were enacted. Thus, for a short period of time, the balance of power in Prussian society shifted away from the landed nobility to a group of progressive bureaucrats that enacted various de jure institutional reforms based on the principles of economic liberalism, including the granting of equality before the law and freedom from personal subjection to the entire population of Prussia from 1810 onwards, as per the "October Edict" of 1807. Although the October Edict did not necessarily dissolve the bonded servile duties owed to the nobility by the peasantry, or even specify how peasants could redeem their lifetime labor dues, it ended the nobility's de jure monopoly over the ownership of large manorial (knight) estates. This was followed by the "Regulation Edict" (Regulierungsedikt) of 1811, which granted peasants holding weak (i.e., non-hereditary) land tenure the legal right to ownership of the lands that they farmed as well as the ability to redeem their lifetime servile dues, but only upon handing over between a third and two-thirds of these lands to their former manorial lords as compensation. ${ }^{21}$

The process leading up to the full de facto emancipation of the peasantry, however, extended well into the final decades of the nineteenth century, as the balance of power shifted back towards the conservative landowning nobility, in the aftermath of the German Campaign of 1813 that effectively ended the short-lived domination of Prussia by the French with Napoleon's defeat at the Battle of Leipzig. Following the Congress of Vienna in 1815, the Kingdom was established within new borders, regaining most of its territories lost during the Napoleonic wars and annexing new territories in the western regions of the former Holy Roman Empire (Rhineland and Westphalia) and in Saxony. As a result of conservative opposition to the reforms from a rehabilitated landed aristocracy, the Regulation Edict (as it applied to both landownership and emancipation reform) was amended by the "Declaration" of 1816 to exclude peasants residing on small parcels of land (nichtspannfähige Nahrungen) from acquiring allodial title rights and, thus, from also redeeming their lifetime servile dues to the nobility.

A further step towards increased de facto emancipation of the peasantry occurred in 1821, when the "Dissolution Ordinance" (Ablösungsordnung) clarified how peasants holding strong (i.e., hereditary) land tenure could terminate their feudal labor relations; namely, by compensating their manorial lords with 25 times the annual value of forgone services and labor dues in either money or land. Thus, in spite of de jure emancipation, the obligation borne by the peasants to substantially compensate their manorial lords, combined with the bargaining power of the landed nobility over certain terms of redemption process (to be discussed below), effectively stretched de facto emancipation into a long and heterogeneous process across regions and even estates throughout nineteenth-century Prussia. ${ }^{22}$ Moreover, it was only after the passage of the "Commutation Law" of 1850, adopted by the new parliament in the aftermath of the German Revolution of 1848-1849, that surviving servile duties, particularly those associated with peasants residing in the small land

\footnotetext{
${ }^{21}$ Interestingly, the anecdotal evidence from historians suggests that at least part of the motivation for these reforms amongst the reformers themselves was the attainment of higher economy-wide productivity. For instance, as Reddy (1987, p. 84) notes, "Hardenberg had promised in 1811 that "the state would thus acquire a new, estimable class of motivated property owners" and that "through the desire to enter this class, the cultivation of the soil would profit from more hands, and through their greater effort, because freely given, more work as well."”

${ }^{22}$ For a nuanced picture of the emancipation process in Prussia, see Eddie (2013).
} 
parcels that were excluded from emancipation by the Declaration of 1816, could be de jure liquidated via redemption payments to the nobility.

In addition to generating heterogeneity in the de facto emancipation process across Prussia, the agrarian reforms of the early nineteenth century served to alter the composition of the landed nobility towards an ever increasing representation of the bourgeoisie. As mentioned previously, a significant aspect of the October Edict of 1807 was the termination of the nobility's monopoly over manorial landownership, thereby permitting the free trade of noble estates. Following Prussia's defeat to Napoleon in 1806, the market for noble estates was opened to commoners as part of an effort to recapitalize the economy, which was now overburdened by its enormous reparations to France. Consequently, the capital market witnessed an increase in the trade of manorial estates and, according to Schiller (2003, p. 477), the replacement of less productive noble estate owners. Once the market became accessible to commoners, the early purchasers of knight estates were primarily merchants and industrialists from Berlin, but the group included mill owners and master masons as well (Schiller, 2003, p. 259). By the mid-nineteenth century, however, a significant share of manorial estates were owned by the non-nobility, and the sizable representation of the bourgeoisie amongst these non-noble estate owners led to a "socially mixed elite of landed businessmen" (Bowman, 2011, p. 33$).^{23}$

\subsection{Redemption of servile dues and peasant mobility}

As mentioned previously, despite the de jure emancipation of the peasantry under the October Edict, the rehabilitation of the landed nobility in the period following the Congress of Vienna permitted them to exert substantial control over the pace of the de facto emancipation process, by conditioning the terms associated with the redemption of lifetime servile dues to reflect their own economic interests. This is an important aspect of the Prussian peasant emancipation experience as it suggests that the progressive nobility and the landed bourgeoisie may have been willing to accelerate emancipation by settling for terms that were more favorable to their peasants. ${ }^{24} \mathrm{We}$ provide a brief narrative below on the redemption process itself and how the elites came to exert their authority over this process, thereby influencing the pace of de facto emancipation following the Prussian agrarian reforms.

The redemption process (Reallastenablösung) associated with each emancipation case was overseen by the General Commission (Auseinandersetzungsbehörden), staffed with public officials possessing legal training and knowledge of agricultural markets. At the highest level of administration, the Commission comprised a total of 6 agencies, each holding jurisdiction over several districts. At the lowest administrative level, the county mediation agency (Kreisvermittlungs-

\footnotetext{
${ }^{23}$ Indeed, as Bowman (2011, p. 32-33) asserts, "[t] he influx of commoners into the ranks of Junkerdom spurred what Reinhard Koselleck calls "the creeping transformation of the landed nobility (Ritterstand) into an entrepreneurial class of manorial lords (Gutsherren)."”"

${ }^{24}$ Historical accounts of the time are suggestive of the prevalence of such incentives amongst the elites. Specifically, Schissler (1978, p. 126) discusses how noble estate owners in Pomerania renounced some of the land they were entitled to as compensation for forgone servile dues. The estate owner, Ernst von Büllow-Cummerow, for example, welcomed the abolition of serfdom, based on the idea that free labor would serve to increase land and worker productivity.
} 
behörde) was staffed with 2-6 local officials that were elected by the county assembly and worked closely with the county supervisor (Landrat). Importantly, because the county assembly was predominantly composed of noble landowners, officials at the county mediation agency were typically strongly aligned with entrenched members of the local nobility.

The settlement (Auseinandersetzung) between a manorial lord and his serf peasants was triggered by the so-called "provocation of the redemption" (Provozierung der Ablösungen) and was to be filed with the General Commission. ${ }^{25}$ Either party could initiate the process, resulting in a formal hearing where the exact amount of the compensation payment was to be determined by the parties and arbitrated by an expert. ${ }^{26}$ Contemporary observers from the period acknowledge that forgone labor services were extremely difficult to value, so "norms" for the valuation of compensation payments to the nobility had to be set by central authority (Eddie, 2013, p. 211). Consequently, redemption values were based on either "normal prices" (Normalpreise) or expert judgment.

As noted by Berdahl (1988), following the passage of the Dissolution Ordinance, "tempering of the moderate reforms had begun in the interest of the landowning nobility" (p. 269). The nobility protested against the bureaucratic intrusion into what they deemed to be a "happy patriarchal relationship" on their lands and appealed to the Crown to leave the settlements for the lords to work out with their peasants (Berdahl, 1988, p. 281). In response to these appeals, the General Commission in Königsberg was "ordered to reduce its staff and to plan intentionally for a slower pace of work. Aware of the effects that this order might have on the peasantry, the ministry instructed the commission to keep it secret" (Berdahl, 1988, p. 269). Beyond this growing influence of the nobility on the Crown, the fact that county commissioners were aligned with the nobility meant that the settlement of emancipation cases became subject to the will of the landowners, who often challenged the legal status of the peasants or their eligibility under the regulations with respect to their tenancy rights. ${ }^{27}$

In addition to the considerable influence exerted by the elites on the redemption process, the historical evidence further suggests that they were able to exploit idiosyncrasies in the structure of the reforms to ensure the limited mobility of labor even after the de facto emancipation of their serf peasants. For instance, Skocpol (1979, p. 109) writes that "when serfdom was abolished, the landlords influenced the process in ways that ensured as far as possible the maintenance of their accustomed economic hegemony in new forms. Prussian peasants were forced to cede to the large, Junker-owned estates one-third to two-thirds of the holdings they had worked for themselves under serfdom, in order to gain property title to the lands that remained. This meant that the vast

\footnotetext{
${ }^{25}$ Hagen (2002) provides some detailed micro-historical examples of the redemption process at the noble lordship of Stavenow in the central Prussian province of Brandenburg.

${ }^{26}$ In the event of a dispute where official mediation was required, the local commissioner's job was to determine which land belonged to which party and what the legal status of each landowner was, whether peasant tenancy was hereditary (i.e., if the peasant had strong tenure rights), and whether the peasant landowner was eligible for settlement under the regulation.

${ }^{27}$ The baseline year for the determination of peasant land tenancy was 1752 , and written records from that time were sparse.
} 
majority were left with inadequate land to support themselves, thus ensuring that they would continue to work on the Junker estates, henceforth, as wage laborers."

This is a critical aspect of our empirical setting for three reasons. First, it mollifies the potential concern that the economic incentives of the elites to hasten or delay the de facto emancipation of their serfs, as per our hypothesis, would not have been mobilized unless the elites had prior knowledge of (their ability to ensure) a high degree of spatial segmentation of labor markets for their freed peasants. Second, it suggests that the threat of local labor scarcity arising from peasant workers exploiting potentially better outside options was likely not a primary concern underlying the decision of the elites to accelerate de facto emancipation in order to retain their former serfs under competitive market wages. Finally, it implies that even if better outside options existed for the peasants that initiated the redemption process, they were not necessarily able to exploit these opportunities to expedite the redemption of their lifetime servile dues via compensation payments to their landlords. We will revisit the evidence on the segmentation of labor markets more systematically in our empirical analysis in Section 5.2.

\subsection{Industrialization of the estate economy}

The stereotypical view of the Prussian landowning nobility (Ritterstand) has been one in which the Junkers are seen as a highly conservative reactionary group, strongly attached to class habits and a traditional lifestyle, and focusing almost exclusively on agricultural economic activities. Although the historical literature on the period leading up to and following the agrarian reforms generally acknowledges an increasingly capitalist organization of the estate economy, reflecting advances in crop rotation and agricultural productivity whenever grain prices increased due to high demand, the Junkers are usually not described as being progressive (Rosenberg, 1978; Bowman, 2011; Schiller, 2003; Wehler, 2006).

However, according to Eddie (2008, p. 177), "a mostly overlooked feature of the nineteenthcentury economy of eastern Germany is the significant role that industrial production on agricultural estates played in that economy." Based on information from industrial censuses in the latter half of the nineteenth century, the author affirms the existence of a dense and heterogeneous network of rural-based industrial establishments on large manorial estates (averaging about one establishment for every 2.5 square kilometers), concluding that "the stereotypical picture of Junkerland as being a vast expanse of extensively cultivated estates with almost no industry is clearly wrong" (Eddie, 2008, p. 180). Thus, although the Junkers are not considered to have held any immediate stakes in the proto-industrial economy of pre-reform Prussia (e.g., Carsten, 1988, p. 51), due to the fact the nobility were excluded from bourgeois occupations prior to the October Edict of 1807, the historical evidence clearly suggests that production activities in Junkerdom underwent considerable structural change once these institutional constraints were removed.

Furthermore, the nineteenth-century industrialization of the Prussian estate economy additionally reflects the infiltration of the bourgeoisie into the class of landowning elites in the period

following the agrarian reforms. The case of Johann Gottlob Nathusius (1760-1835) provides a 
prominent illustration of this phenomenon. Nathusius became the richest man in Magdeburg as the first tobacco-factory owner in Prussia in 1787. In 1810/11, he purchased three manorial estates to grow his own tobacco and eventually developed the estates into the first industrial conglomerate in Prussia (Nathusius'sche Gewerbeanstalten), including a porcelain factory, a machine factory (involved in the building of hydraulic presses and steam engines), a sugar refinery, and several distilleries, brick works, and grain mills (Görlitz, 1981). The Nathusius conglomerate eventually gave rise to several spin-off enterprises by former employees and is considered to have strongly influenced the intensity of local industrialization.

In sum, the historical narrative of nineteenth-century Prussia indicates the emergence of significant stakes in industrial production amongst the rural landowning elites, encompassing both the nobility and the bourgeoisie. An integral part of our thesis is that, in the presence of capitalskill complementarity, this process contributed to the mobilization of the emancipation-oriented incentives of the capital-owning elites.

\subsection{Emancipation and worker productivity}

In our conceptual framework, the elites choose to emancipate their serf peasants because they rationally expect worker productivity to be higher for freed labor. Indeed, the evidence from historians suggests a keen awareness amongst members of the Prussian nobility, both in the period leading up to and following the agrarian reforms of the early nineteenth century, that serf emancipation would ultimately serve to raise worker productivity.

The fact that such awareness existed amongst the nobility as early as the mid-eighteenth century is exemplified by the case of Ernst Wilhelm von Schlabrendorff (1719-1769), the son of a knight estate owner, who was appointed minister of Silesia in 1755. According to Melton (1988), Schlabrendorff's emancipation-oriented outlook as Silesia's minister was inspired by his exposure to the experience in the province of Magdeburg, where landlords had already started the process of commutating peasant labor services into quitrents on their own initiative. Specifically, upon returning from an inspection tour of Upper Silesia, where labor coercion of the peasantry was particularly intense, Schlabrendorff wrote to the King recommending the commutation of the peasantry's labor obligations into quitrents, insisting that excessive labor services and the insecurity of peasant land tenure bred discontent and were a barrier to worker productivity. Indeed, Schlabrendorf is quoted by Melton (1988, pp. 154-155) as stating: "It is beyond question that the peasant who works on his own property will labor far more enthusiastically." Another example of early progressivism is the case of Friedrich Eberhard von Rochow (1734-1805), who introduced a small-scale agrarian reform on his own manorial estates in Brandenburg well before the Prussian reforms of the early nineteenth century. Specifically, he enclosed the commons on his estates, turned them into private peasant holdings, and commutated the feudal labor services of his serfs into quitrents. As discussed by Melton (1988, p. 167), von Rochow's local reforms followed a period of intense pedagogical activity, 
based on the nobleman's prior belief that his institutional changes, aimed to increase peasant labor productivity, would be ineffective unless the peasants were sufficiently educated. ${ }^{28}$

Beyond associating labor coercion with reduced worker productivity, the evidence from historians further suggests that some members of the nobility even considered freed workers to be more "appropriate" for the adoption of innovative agrarian production techniques. For instance, according to Carsten (1988), the Geheime Oberfinanzrat von Ernsthausen wrote in 1788 that because peasant labor services were only ever provided with reluctance, labor coercion "had produced major disruptions [to productivity] for centuries" and "choked all engines of invention and improvement." As noted by Carsten (1988, p. 67), "insightful nobles in the late eighteenth century therefore allowed peasant services to be commutated into quitrents and ultimately released their peasants from serfdom. [...] The landlords realized that coerced labor services had lost their value, and for the new agricultural methods, wage workers were more suitable than reluctantly serving peasants." In a similar vein, Berdahl (1988, p. 88) asserts that "many agricultural innovators considered serfdom a major obstacle to the improvement of agricultural productivity. Serfdom came to be seen by many as too inefficient. Albrecht Thaer, the most important proponent of new agricultural methods in Prussia, advocated the emancipation of the serfs; [...] A few estate owners liberated their serfs and adopted a system of wage labor; others reduced the work obligations in exchange for increased rents." Interestingly, echoing the case of the nobleman von Rochow, the historical narrative also indicates the existence of awareness amongst the nobility in the mid-to-late eighteenth century that the reduction of peasant labor services, or their commutation into quitrents, would by itself not be sufficient to increase labor productivity, because such transformation required that peasants gain "self-awareness" as workers through education (Melton, 1988, p. 156-158). ${ }^{29}$

Finally, both the historical narrative and anecdotal evidence attest to the fact that many landlords in the period following the agrarian reforms of the early nineteenth century actually benefited from higher worker productivity, especially from the application of freed labor to new production techniques. In particular, Skocpol (1979, p. 109) states that "once the Prussian reforms had both abolished serfdom and opened the market for noble estates to all well-to-do investors, Prussian landlords [...] could begin to adopt innovative techniques that required "free" wage labor." Furthermore, in discussing the socioeconomic transition from feudal to "capitalist" labor institutions following the agrarian reforms, Biernacki (1995, p. 305) provides anecdotal evidence on how the transformation was viewed by the workers themselves, in the form of a quote from Adam Heuss, who worked for a small hand smith in Nürnberg and published his observations in 1845 . Heuss

\footnotetext{
${ }^{28}$ As part of his educational program, von Rochow built schools on each of his three estates (all of which subsequently became well-regarded model schools throughout Europe), wrote a textbook for the teaching of basic arithmetic and economic thinking (next to the usual religious and moral content), and increased the salary of teachers in his schools to ensure that they would not have to assume secondary occupations.

${ }^{29}$ For instance, Melton (1988, p. 158) notes that "[t]he Schlesische Oeconomische Sammlungen (1755-62), an economic journal to which progressive landowners, estate managers, and agronomists submitted practical articles on estate improvement, proposed creating an economic society devoted to peasant education," with the goal of raising peasant productivity. The historian further highlights the case of Johann Georg von Dresky, an enterprising Silesian landowner and a member of the Silesian Economic-Patriotic Society, arguing that the nobleman "considered the peasantry's lack of education to be the major barrier to increased agricultural productivity."
} 
remarks that in his "age of mighty advance," it was considered "advantageous" to have "tradable wares manufactured in factories with machines." He additionally illustrates the incentives of the elites, citing the case of the "Mecklenburger estate lords [Gutsherren] who released their subject peasants and turned them into day laborers."

Indeed, the changing incentives of the elites are perhaps best exemplified by the aforementioned case of the rural industrialist Nathusius. Specifically, in discussing the status of peasants on the manorial estates that he purchased, his daughter and biographer writes: "at first the peasants served him, but he soon insisted on a cheap [emphasis added] redemption for them" (von Nathusius, 1915, p. 239). Moreover, in line the increased demand for skilled workers by capitalist elites, Nathusius' biography (p. 237) further states that "[h]e vigorously advocated for better instruction in the schools, especially for the practical sciences, and also in rural schools, which represented the best means of uplifting industry." Thus, it is evident that landlords not only perceived freed workers to be more productive but actually reaped these benefits by facilitating the emancipation of their serfs, employing them as free workers in more innovative production activities, and encouraging their acquisition of complementary skills.

\section{Data}

Our empirical analysis aims to document reduced-form patterns that are consistent with our hypothesis regarding the decline of serfdom in nineteenth-century Prussia. Specifically, we link capital ownership by the elites in early stages of industrialization with the subsequent intensity of labor emancipation. This section discusses the most relevant aspects of our dataset, relegating additional information to Appendix A.

\subsection{Serf emancipation}

We employ administrative data on de facto serf emancipation, obtained from sources published by the Prussian Statistical Office and first presented in Meitzen (1868) for the purposes of documenting the progress achieved by the emancipation process by the mid-nineteenth century.

The dependent variable in our cross-sectional analysis is based on the county-level cumulative stock of emancipation cases (Rezesse) settled as of 1848. Thus, we attempt to explain the observed variation in labor emancipation at this highly disaggregated administrative level in Prussian regions east of the river Rhine. ${ }^{30}$ The original data tables indicate the specific legislation under which each emancipation case was settled, and we exploit this information to focus our measure on the number of former service and duty payers (Dienst- und Agabenpflichtige, welche

\footnotetext{
${ }^{30}$ We structure our county-level data set to consistently link information from different censuses over time. The original sources exclude regions west of the river Rhine, where, due to the Napoleonic occupation, agricultural and emancipation reforms developed in a radically different fashion than in the rest of Prussia. This also applies to the district of Stralsund, where such reforms had been introduced by the Swedish Crown in 1806. Furthermore, no information is available for the city counties, presumably because serfdom was not at all prevalent in these purely urban areas.
} 
abgelöst haben) who redeemed their lifetime servile duties under the Dissolution Ordinance of 1821 (Ablösungsordnung). This permits us to capture precisely those cases in which, upon settlement, the former serfs were no longer required to provide labor services to their manorial lords. In addition, for each case, Meitzen (1868) reports the number of redeemed days of service as well as the cost of redemption. We use this information in our analysis to account for the average intensity of coercion and, in a different exercise, to explore cross-county variation in the average cost of redemption itself. ${ }^{31}$

In light of the fact that our dependent variable focuses on emancipation cases settled under the 1821 ordinance, it is important to understand the extent to which this legislation influenced the de facto peasant emancipation process in Prussia. Recent estimates have placed the number of rural households in early-nineteenth-century Prussia at approximately one million: ca. 710,000 peasant households and 283,000 lodgers (Eddie, 2013). Of these rural households, roughly 11-13 percent held only weak (non-hereditary) rights to land tenure and were thus emancipated under the terms of the 1811 regulation and its 1816 amendment. The remaining majority of households, however, held strong (hereditary) rights to land tenure, and their emancipation was therefore exclusively governed by the terms of the 1821 ordinance.

One shortcoming of our data set is that precise information on the initial population of serfs (i.e., as of the early nineteenth century) is not available. In order to arrive at a measure of the intensity of serf emancipation, we must therefore rely on approximations of the initial serf population. Our preferred measure for normalizing the cumulative stock of settled emancipation cases at the county level is the rural population of the county as of 1816 , net of the population in small peasant landholdings that were only able to emancipate after the Commutation Law of 1850 was issued. ${ }^{32}$

As is evident from the map in Figure 2, there is considerable variation across Prussian counties in the intensity of the de facto serf emancipation process as of 1848. In particular, the share of emancipated serfs at the county level ranges from $0 \%$ to $52 \%$ and has a mean of $6 \%$. This distribution reflects a relatively advanced emancipation process in many counties belonging to the

\footnotetext{
${ }^{31}$ The data on Prussian serf emancipation are discussed by Harnisch (1974), who finds inconsistencies in the information for 1838 versus 1848. Although concerns regarding the number of settled cases are not raised, Harnisch questions the reliability of the data on redemption costs reported for 1848. According to Harnisch, the statistics, published shortly after the events of the German Revolution of 1848, may systematically underreport the actual redemption payments. In fact, it is plausible that redemption payments were only applicable to emancipation cases settled under the 1821 ordinance, thus creating the inconsistencies identified by Harnisch, and it is for this reason that we focus only on those cases.

${ }^{32}$ In using this measure, we assume that the entire rural population of a county, including peasant family members, farm hands, and day laborers, were bonded serfs engaged in the provision of servile labor duties. To account for persistent systematic differences across counties in the size of peasant households, our empirical model will include average family size in 1849 as a covariate. To address other potential sources of systematic measurement error in our dependent variable, we will additionally control for heterogeneity in both the prevalence of free peasants and the legal status of serfs across counties. Our main findings prove to be robust to the use of alternative measures for normalizing the stock of settled emancipation cases at the county level, including the total population in 1816, the rural population including peasant landowners of small parcels in 1816, the number of servants in agriculture in 1816 , the number of peasant landholdings in 1816, the number of full-time peasants including family and farm hands in 1849 , the number of full- and part-time peasants including family and farm hands in 1849 , or the number of peasant landholdings in 1849 .
} 


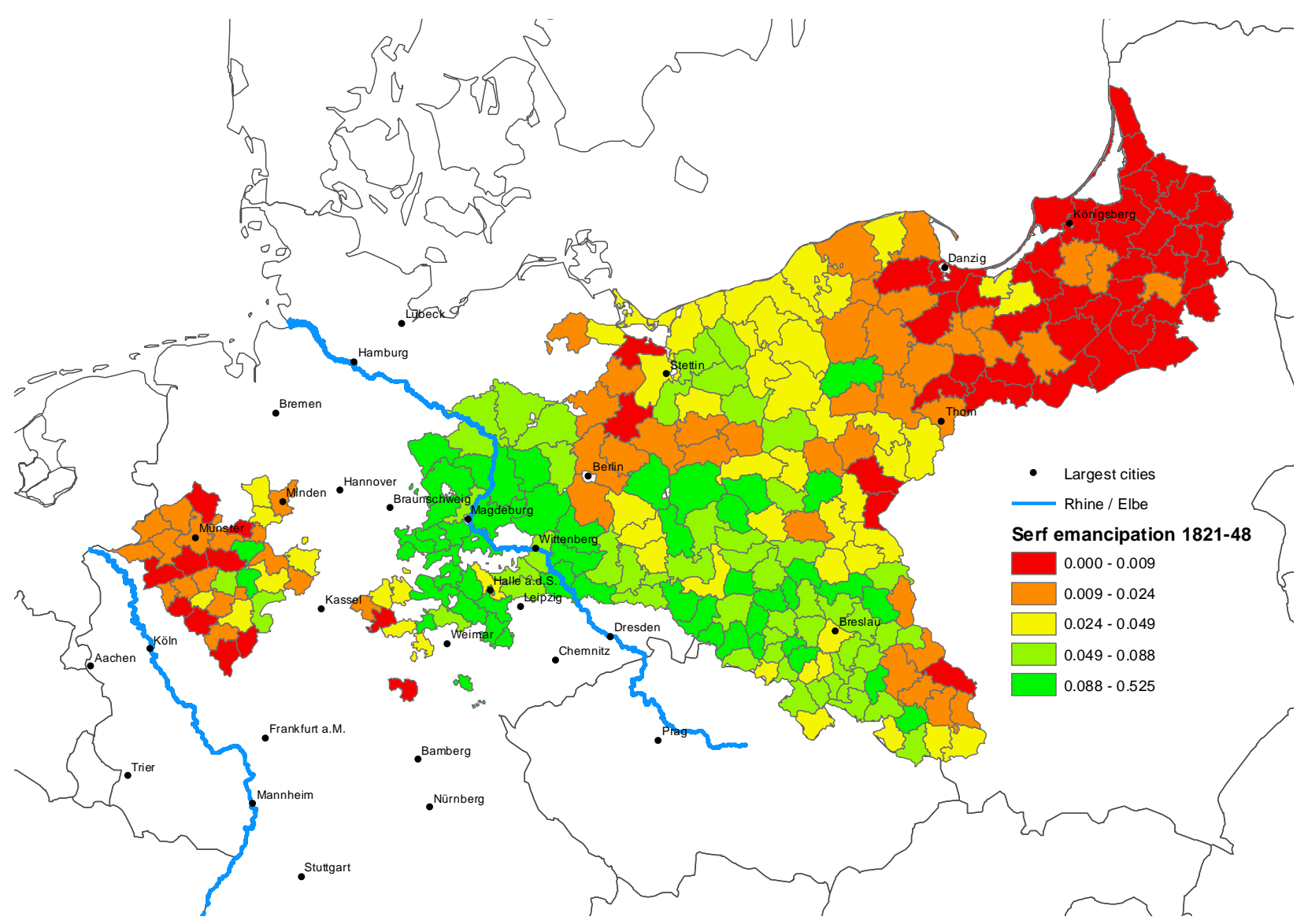

FiguRE 2: Spatial distribution of serf emancipation intensity as of 1848

Notes. This map illustrates the distribution across Prussian counties of the share of emancipated serfs in 1848 . This variable is measured as the total number of emancipation cases settled in a county (under the 1821 ordinance) as of 1848, expressed as a fraction of the rural population of the county in 1816 (net of the population in small peasant landholdings). See the discussion in the main text and Appendix A for additional details.

central and southeastern provinces of Saxony, Brandenburg, and Silesia, and predominantly low emancipation shares in the eastern regions of Prussia and the western province of Westphalia.

In addition to the cumulative stock of emancipation cases settled by 1848, our historical data sources provide information on the number of cases settled each year during the 1850-1898 time horizon, but only at the more aggregated administrative level of districts. In Section 5.3, we employ these district-level data to conduct a flexible panel analysis of the temporal flows of emancipation cases. Importantly, the inclusion of district fixed effects in this analysis implies that it will be able to account not only for the potentially confounding effects of time-invariant geographical, cultural, and institutional characteristics at the district level but also for any measurement issues associated with the absence of precise information on the initial population of serfs. 


\subsection{Proto-industrialization and elite capital-ownership}

The first half of the nineteenth century is generally regarded as the period during which the foundations for Prussian industrialization were laid. The accumulation of physical capital during this period was concentrated in the agricultural sector and was largely driven by investments in livestock, seed, and buildings (Tilly, 1978). Since neither livestock nor seed is directly associated with proto-industrial production, our empirical analysis instead focuses on a specific type of productive physical structures - namely, water mills - on which the data are available for the early nineteenth century at a spatially disaggregated level. In particular, we use the number of water mills per 1,000 inhabitants in 1819 as a proxy measure of the extent of proto-industrialization at the county level. Three characteristics of this measure make it particularly relevant in our setting.

First, the ownership of water mills in this period was almost exclusively restricted to the nobility, thus ensuring that the rents associated with milling were available for reinvestment and subsequent capital accumulation by the elites. Prior to the agrarian reforms of the early nineteenth century, the construction and operation of a grain mill was a noble prerogative. The seigniorial rights of a feudal lord encompassed the monopoly privilege of grain milling on his estate, including (i) the legal obligation that all local peasants exclusively grind their grain in the mill on their landlord's estate (Mühlenzwang or suit of mill); and (ii) the right of the lord to additionally tax the milled grain (Mahlsteuer or multure). ${ }^{33}$ Historians agree that the seigneurial rights associated with grain milling conferred considerable profits to the landed nobility (e.g., Bloch, 1967; Hills, 1996; Lucas, 2006; van der Beek, 2010). Consequently, the returns from the ownership of water mills not only accrued exclusively to the nobility but were also sufficiently large for exploiting reinvestment opportunities. ${ }^{34}$

Second, the use of water mills in early stages of industrialization arguably foreshadowed the subsequent adoption of a well-known skill-intensive technology during more mature stages of industrialization - namely, the steam engine. ${ }^{35}$ In particular, economic historians of the Industrial Revolution have argued that early investments in water mills - the proto-industrial installations most closely related to steam engines because of their reliance on water availability - may well have made the adoption of steam-engine technology more "appropriate" over the course of industrialization. For instance, Mokyr (2002, p. 256) states that "[...] the owner of machines that become obsolete will take a loss on those machines, but he can always buy into the new technology by purchasing new machines that yield higher profits through lower costs. This explains, for instance, the relatively weak resistance to the introduction of steam engines despite the huge locational rents that

\footnotetext{
${ }^{33}$ The suit of mill was effectively a ban on local peasants to grind their grain using personal hand mills. The multure tax rate was often quoted at $1 / 16$.

${ }^{34}$ Indeed, as claimed by Hills (1996, p. 26-27), "[t]he rights to a watermill were owned by the lord of a manor and, in an age when there were no stocks and shares to provide an income, the corn mill presented one of the few profitable capital investments available. [...] Once the mill was established, it became another potential capital investment and, with the 'soke' or control over the milling rights which the lord of the manor held, the mill became something worthwhile building and owning [...]."

${ }^{35}$ See, for instance, Franck and Galor (2017) for systematic evidence linking the adoption of steam-engine technologies in mid-nineteenth-century France with broad increases in literacy rates and educational attainment.
} 


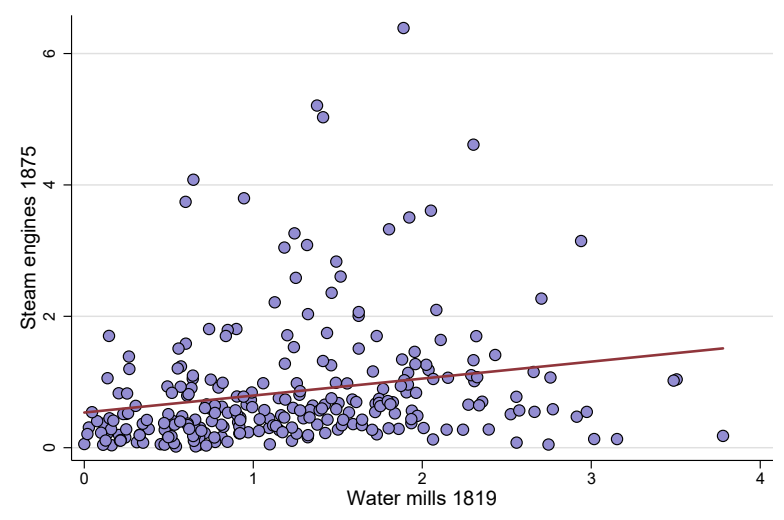

Slope coeff. (S.E.) = 0.258 (0.097); Adj. R2 = 0.04; Obs. = 261

(a) Steam engines

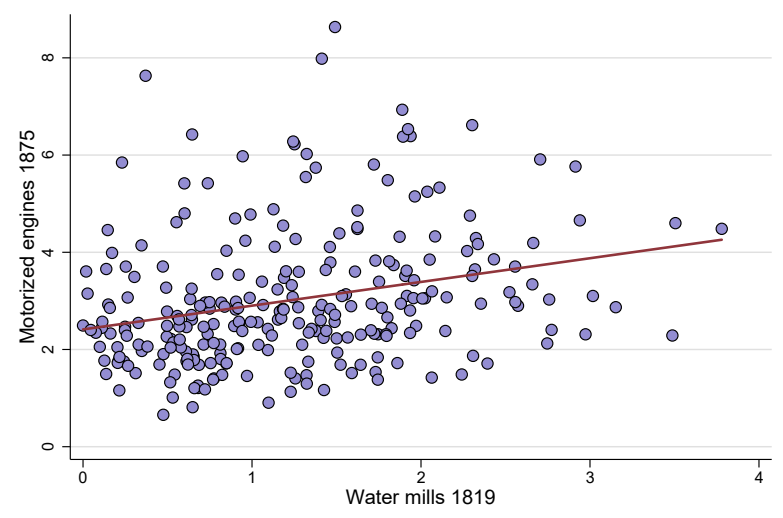

Slope coeff. (S.E.) $=0.488$ (0.186); Adj. R2 $=0.07 ;$ Obs. $=261$

(b) All motorized engines

FiguRE 3: Water mills in 1819 and motorized engines in 1875

Notes. These scatter plots each illustrate the significant positive relationship across Prussian counties between the extent of proto-industrialization, as measured by the number of water mills per 1,000 inhabitants in a county in 1819, and the subsequent adoption of skill-intensive industrial techniques, as measured by the total number of either steam engines (panel (a)) or all types of motorized engines (panel (b)) across industrial establishments per 1,000 inhabitants in the county in 1875. See the discussion in the main text and Appendix A for additional details.

were being secured by the owners of water mills sites. Industrialists using water power might have been losing when their mills fell into disuse, but they could make up for those losses by buying into steam technology themselves, which is precisely what happened in Lancashire during the British Industrial Revolution." In the context of nineteenth-century Prussia, the idea that the early use of water mills may have foreshadowed skill-intensive industrialization later on is empirically vindicated by the scatter plot in panel (a) of Figure 3, which documents a statistically significant positive association across counties between the prevalence of water mills (per 1,000 inhabitants) in 1819 and the adoption of steam engines (per 1,000 inhabitants) in 1875. Furthermore, as shown in panel (b), the connection between our measure of proto-industrialization and the future use of advanced technologies in industrial establishments is in fact more general, extending to all types of motorized engines.

Third, the fact that the operability of water mills requires certain preconditions in the structure of the local terrain (to be elaborated upon in Section 5.1) permits our analysis to exploit a plausibly exogenous source of variation in the extent of proto-industrialization across counties, in order to mitigate the issue of omitted variable bias. ${ }^{36}$

The map in Figure 4 illustrates the spatial distribution of water mills per 1,000 inhabitants across Prussian counties as of 1819. Our measure has an average value of 1.2 and ranges from 0 to 3.8 , reflecting higher capital ownership by the elites in Westphalia and in the central regions of Saxony and Silesia, relative to the eastern regions of Prussia.

\footnotetext{
${ }^{36}$ Although the provided arguments make the prevalence of water mills our measure of choice, all our findings remain robust to using the number of private dwellings in 1819 as an alternative proxy for the initial stock of physical capital at the county level.
} 


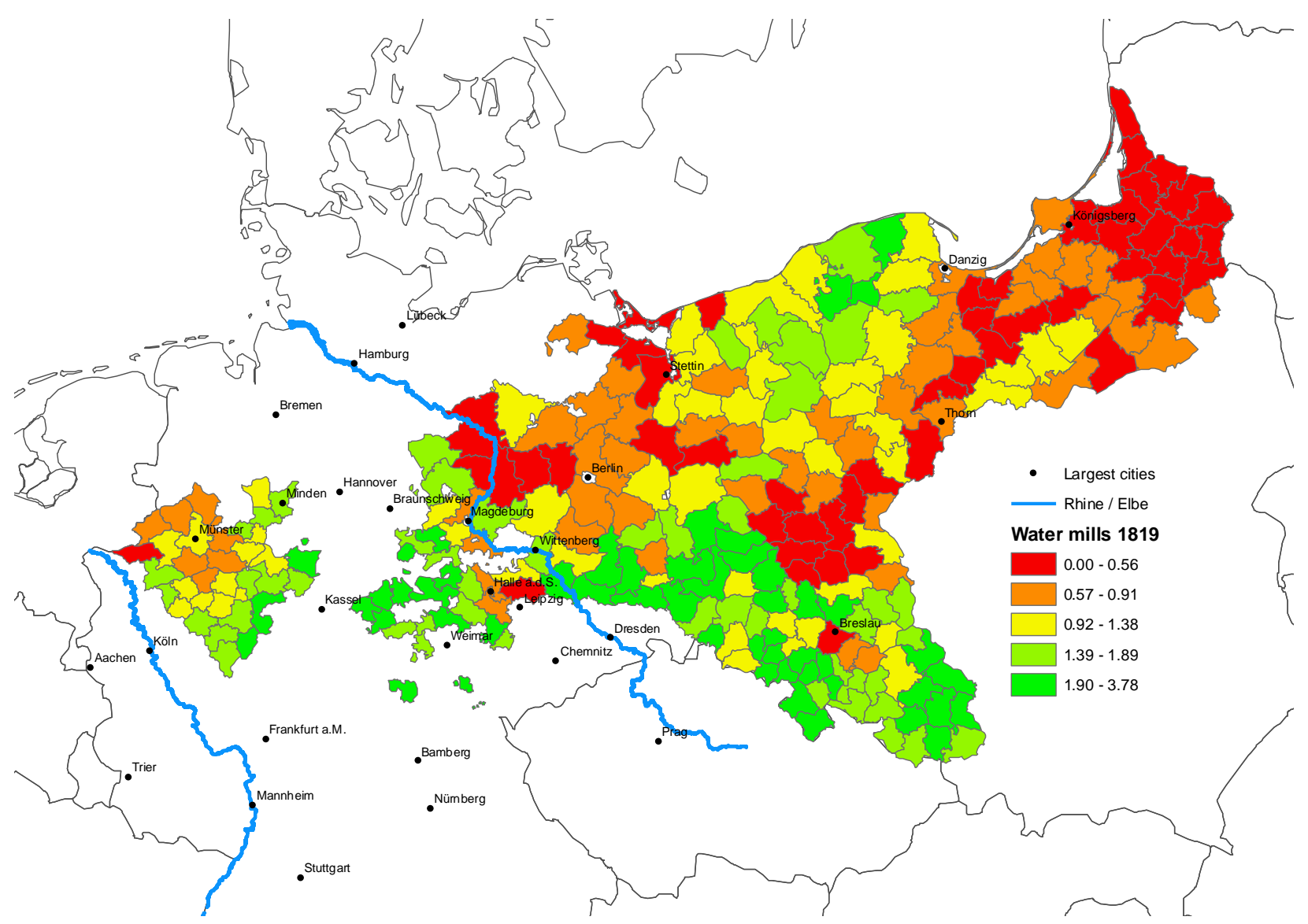

FiguRE 4: Spatial distribution of rural elite capital ownership in 1819

Notes. This map illustrates the distribution across Prussian counties of our proxy measure of proto-industrialization in 1819. This variable is measured as the number of water mills in a county in 1819, divided by the population (in thousands) of the county in 1821 (the population census year closest to 1819). See the discussion in the main text and Appendix A for additional details.

\subsection{Control variables}

Our empirical analysis accounts for a sizable set of potentially confounding factors at the county level that may have not only affected the pace of early industrialization but also influenced the bargaining power of peasants and the incentives of the elites to relinquish labor coercion, thereby conditioning the rate of serf emancipation. The first set of control variables is aimed at accounting for spatial heterogeneity in geographical endowments that can directly influence agricultural productivity and access to markets and can also indirectly affect cultural and institutional characteristics through various mechanisms. Specifically, our geographical control variables include temperature, precipitation, soil suitability for cereal crops, the share of sand in the top soil, and distance to navigable rivers. We also include an indicator for counties east of the river Elbe, where both coercive labor institutions and dependence on large-scale agriculture are known to have historically evolved in a characteristically different fashion than in the western regions of Prussia (see, e.g., Harnisch, 1986; Melton, 2000). 
Our second set of control variables is intended to capture variations in admittedly less exogenous but more proximate potential confounders. In particular, we introduce controls for population density and urbanization rate in 1816, in order to account for heterogeneity across counties in initial development, labor abundance, and access to urban markets. Peasant-household demographic factors and the initial intensity of investments in human capital, both of which can influence the incentives of the elites to emancipate while also affecting industrialization, are accounted for by measures of average family size (only available from the 1849 census onward) and the enrollment rate in public primary schools in 1816. Differences across counties in the cultural propensity to emancipate and/or industrialize (as well as the correlated tendency to attract immigrants) are captured by controls for the share of Protestants in the population in 1816 and the share of individuals of non-Germanic (mostly Slavic) ancestry in the population (only available from the 1861 census onward).

In addition, our second set of covariates includes two measures that account for institutional differences across counties in the structure of peasant and noble landholdings. Such distinctions could have influenced the ability of the peasantry to compensate the landlords for the redemption of lifetime servile dues as well as the incentives of the elites to delay both serf emancipation and the adoption of industrial production techniques. Our first measure is an indicator for the predominant law of succession that governed the inheritance of peasant landholdings in a county; namely, partible inheritance (Realteilung), characterized by the equal division of land across heirs, versus impartible inheritance (Anerbenrecht) or primogeniture. This indicator is aimed at capturing the potentially confounding demographic and economic effects associated with the larger average size of peasant landholdings in counties that overwhelmingly practiced impartible inheritance. ${ }^{37}$ Our second measure captures the share of all landholdings in a county that were designated as knight estates (Rittergüter). These large manorial estates are known to have been historically associated with stronger feudal institutions and, thus, stronger vested interests of the landed aristocracy in the appropriation of serf labor for large-scale farming activities (Cinnirella and Hornung, 2016a).

The final set of covariates considered by our analysis includes additional proxy measures capturing some of the alternative mechanisms mentioned above as well as other potential confounders. Specifically, omitted variable bias due to heterogeneity across counties in access to external (urban) markets or "outside" employment options for the enserfed population is further addressed by the inclusion of three dummy variables, indicating (i) the presence of at least one main road (on which the earliest reliable information is for 1848); (ii) the presence of a railway line (also in 1848, noting that railroad development in Prussia began in 1838), and (iii) the presence of coal mining. Relatedly, we also control for the share of the population born outside the county (available from the 1871 census), employing this ex post realization to partly account for the ex ante possibility

\footnotetext{
${ }^{37}$ For instance, historians have associated impartible inheritance not only with peasant demographic outcomes like lower fertility and marriage rates, smaller family size, and higher out-migration from rural areas but also with structural economic outcomes like the persistence of large-scale agriculture and the late emergence of concentrated industrial activities (see, e.g., Habakkuk, 1955; Rudolph, 1995; Grant, 2005).
} 
that upon emancipation (and in the absence of labor market segmentation), former serfs could have migrated away to seek employment in external markets offering better opportunities.

Furthermore, differences in the economic incentives of the elites to prolong the use of serf labor as well as variation in the ability of the enserfed population to redeem their lifetime servile duties (following de jure emancipation) are accounted for by a measure of prevailing coercion intensity, reflected by the average number of days of labor services per emancipation case for which the landlords required compensation under the redemption agreement. ${ }^{38}$ We also control for the number of social uprisings during the 1816-1847 time period, in an attempt to account for differences across counties in the strategic incentives of the elites to grant emancipation when faced with a credible threat of mass revolts. ${ }^{39}$ Such perceived threats could have been either suppressed in regions where the elites owned more resources to counter social unrest or intensified by the greater attractiveness of these resources for mass appropriation.

Lastly, our final set of covariates additionally includes two variables aimed at capturing the non-uniform distribution of free peasants in the population across counties prior to the de jure abolition of serfdom. This allows us to account not only for differential incentives of the elites to grant emancipation in the presence of free peasants (e.g., delaying emancipation by allocating serf labor to agriculture and hiring free labor for industrial production) but also for differential convergence across regions to a state of full emancipation (i.e., counties with a larger initial share of free peasants emancipated less because they had smaller enserfed populations to begin with). At the turn of the nineteenth century, certain peasant groups like Schulzen and Köllmer accounted for only about $4 \%$ of rural households across Prussia, but they enjoyed personal freedom and were required to provide only minor dues in quitrents or labor services to the nobility (Eddie, 2013). Although county-level data on the population of free peasants during this period is unavailable, we exploit two relevant proxy measures. The first measure captures the share of estates in a county that operated under the so-called Kulm law, a legacy of the Monastic State of the Teutonic Knights (1230-1525). These Köllmer estates, mostly prevalent in the areas surrounding the towns of Kulm and Thorn, were established during the era of the Teutonic Order and provided the settled peasant population with long-term legal protection from landownership exclusion and enserfment. Our second measure reflects the share of land in a county owned initially by the Prussian Crown and

\footnotetext{
${ }^{38}$ As explained in Appendix A, we construct this measure by extracting the first principal component of the average amounts associated with two different types of labor services that peasants needed to redeem as part of their settlements with the landlords.

${ }^{39}$ Our measure includes not only peasant rebellions but also uprisings involving commoners. In fact, peasant uprisings in Prussia were virtually nonexistent in the period following the introduction of the agrarian reforms and until the German Revolution of 1848-1849. Specifically, the historical evidence (e.g., Carsten, 1988, p. 82) indicates that peasant rebellions in early nineteenth-century Prussia occurred predominantly in the province of Silesia between 1809 and 1811, and even these were primarily due to a misunderstanding of the October Edict by the enserfed Polish-speaking population of the region (which had misinterpreted the legislation as abolishing not just the personal subjection of peasants but their servile duties as well). These uprisings, however, are the only known peasant rebellions of the period during and following the reforms, an outcome partly attributable to the economic recovery of Prussia in the 1820s and the fact that, because the Dissolution Ordinance granted serfs the right to initiate the redemption process, revolts for the purpose of instigating the elites to emancipate were not necessary. Nevertheless, our measure of social uprisings is intended to control for the possibility that the elites may have perceived non-peasant uprisings as potential triggers for more widespread revolts.
} 
later on by the state. Peasants residing in these royal domains were granted personal freedom as early as 1799 and were subsequently able to engage in the commutation of dues and labor services into cash rents, with about one-third of these peasants attaining full redemption of lifetime servile duties and about one-tenth purchasing their lands by 1806 (Eddie, 2013, p. 185).

\subsection{Other outcomes}

To provide corroborating evidence in support of our interpretation of the role of early industrialization in the subsequent de facto emancipation of labor, our empirical analysis additionally explores the links between (i) capital ownership by the elites in the early nineteenth century and their willingness to settle for lower compensation payments in redemption agreements with their serfs, conditional on the prevailing intensity of labor coercion, and (ii) the intensity of de facto serf emancipation as of the mid-nineteenth century and the subsequent accumulation of human capital by the masses, conditional on the extent of early industrialization.

Our outcome measure for exploring the first link is based on the average compensation payments made to the landlords (for redeeming lifetime labor services) per emancipation case settled in a county by 1848 , under the Dissolution Ordinance of $1821 .{ }^{40}$ For examining the second link, we employ two different outcome measures. The first measure captures the enrollment rate in primary schools in 1864, based on county-level census information on both total attendance across primary schools and the population of children of recommended school age (6 to 14). The second measure reflects the literacy rate amongst the population aged 10 and above in a county, based on information available from the 1871 census.

Table A.1 in Appendix A provides the descriptive statistics for all variables considered by our cross-sectional analysis, including our measure of terrain slope (to be introduced in the next section) that we exploit as a plausibly exogenous source of variation across counties in the prevalence of proto-industrialization and early capital ownership by the elites.

\section{Empirical analysis}

\subsection{Cross-sectional specification and reduced-form identification}

\subsubsection{The empirical model}

Our conceptual framework suggests that the historical decline of serfdom in nineteenth-century Prussia can be partly explained by the emergence of capital-ownership amongst the class of manorial lords, which served to mobilize their incentives to emancipate labor in order to reap higher returns to physical capital arising from the nascent complementarity between capital and free workers over the course of industrialization. In empirically exploring our hypothesis, we therefore aim to establish a robust link between the prevalence of proto-industrialization or early capital accumulation by

\footnotetext{
${ }^{40}$ To be precise, it is the first principal component of the average amounts associated with four different types of compensation payments made by peasants in their settlements with the landlords. See Appendix A for additional details.
} 
the elites and the subsequent intensity of de facto serf emancipation in a cross-section of Prussian counties. Specifically, we estimate the following linear model using ordinary least squares (OLS):

$$
\text { Emancipation }_{i, 1821-48}=\alpha+\beta \cdot \operatorname{Mills}_{i, 1819}+\mathbf{X}_{i}^{\prime} \cdot \boldsymbol{\Lambda}+\mathbf{Z}_{i}^{\prime} \cdot \boldsymbol{\Theta}+\varepsilon_{i}
$$

where, as discussed earlier in Section 4.3, the vector $\mathbf{X}_{i}$ represents our first set of covariates, capturing relevant exogenous geographical characteristics in county $i$, the vector $\mathbf{Z}_{i}$ includes our second and third sets of covariates, comprising less exogenous but more proximate potential confounders of the relationship between early industrialization and subsequent serf emancipation, and $\varepsilon_{i}$ is a county-specific disturbance term.

The coefficient of interest, $\beta$, relates our proxy measure of vested interests in the emancipation of the peasantry arising from early capital-ownership amongst the elites with the subsequent intensity of de facto serf emancipation, after partialling out the potentially confounding effects of $\mathbf{X}_{i}$ and $\mathbf{Z}_{i}$. Under the "reduced form" interpretation of our hypothesis, $\beta$ is expected to enter our regressions positively and significantly. In our empirical analysis, we will begin by estimating the bivariate relationship of interest and will then incrementally add control variables from $\mathbf{X}_{i}$ and $\mathbf{Z}_{i}$ to our estimating equation, in the build-up towards our full empirical model. This will facilitate an assessment of the stability of our coefficient of interest when conditioned on different (sets of) covariates, thus permitting a proper evaluation, based on selection on observables, of potential bias arising from selection on unobservables (Altonji et al., 2005). Finally, to account for possible interdependence of error terms across counties within larger administrative units, we cluster the standard errors at the district (Regierungsbezirk) level. Overall, the 261 counties in our full sample belong to nineteen districts. ${ }^{41}$

\subsubsection{Mitigating endogeneity}

Since our explanatory variable of interest, that is, the number of water mills per 1,000 inhabitants, corresponds to a census year that precedes the time horizon over which the intensity of de facto serf emancipation is measured, reverse causality is not likely to be a major source of concern. On the other hand, although our estimating equation includes a considerable set of potentially confounding factors, the prevalence of water mills in 1819 may still be correlated with the error term due to omitted variables. In particular, heterogeneity across counties in unobserved mechanisms that may have contributed to both proto-industrialization and the pace of de facto serf emancipation would bias our coefficient of interest in favor of rejecting the null hypothesis. We attempt to mitigate this issue by exploiting an exogenous (and, arguably, conditionally excludable) source of variation across counties in the prevalence of water mills in the early nineteenth century.

\footnotetext{
${ }^{41}$ Alternatively, to allow for a more general form of spatial correlation in error terms across counties, we implemented the "Conley correction" for all of our main specifications, using various spatial cutoffs in the range of 50 to 250 kilometers. As it turns out, the resulting standard errors are very similar to their baseline estimates reported below, and the statistical significance of the relationship of interest remains unaffected.
} 
There are two apparent forces that determined the spatial distribution of water mills across counties in nineteenth-century Prussia. First, as mentioned in Section 4.2, a water mill could only be operated on a manorial estate if the lord was licensed to do so under a suit of mill granted by the King, but this institutional constraint on the prevalence of water mills in a given region was likely endogenously determined with other forces that shaped the historical evolution of both coercive labor institutions and capital-ownership by the elites in that region. Second, certain features of the physical environment determined the suitability of a region for the effective operation of water mills. Specifically, because terrain undulation affects the natural speed of running water (and, thus, the hydraulic energy potentially harnessable by water mills at the time), the average slope of the terrain in a region had a non-monotonic influence on the region's suitability for operating water mills. At one end of the spectrum, terrains that are too flat did not permit the natural movement of water to be associated with a sufficient amount of kinetic energy. At the other end, however, in terrains that are too steep, such energy could not be feasibly harnessed, given the constraints imposed by the frontier of engineering technology in the early nineteenth century.

We measure the average slope of a county's terrain using geospatial elevation data at a 30-arc-second resolution by first computing the maximum difference in elevation between each grid cell and its eight contiguous neighbors and then calculating the average across all the grid cells of the county. The scatter plot in Figure 5 depicts the significant non-monotonic influence of terrain slope on the prevalence of water mills in our sample. We exploit this pattern in the first stage of a two-stage least squares (2SLS) estimation framework to mitigate the potential omitted variable bias afflicting our coefficient of interest under OLS. Nonetheless, one may still harbor admittedly valid concerns regarding the excludability of terrain slope from the second stage of our 2SLS framework, namely, the possibility that terrain slope could have influenced the pace of de facto serf emancipation through mechanisms other than the prevalence of water mills in the early nineteenth century. Below, we provide several arguments to alleviate such concerns.

First, our analysis directly accounts for the immediately obvious alternative mechanisms through which terrain structure could influence the strength or persistence of coercive labor institutions. Specifically, since average terrain slope could be correlated with local climatological and ecological features that affect the agricultural productivity of land, our analysis controls for variations across counties in temperature, precipitation, and different measures of soil quality. In addition, because terrain undulation is expected to be associated with higher transportation costs and thus weaker integration of goods and factor markets across space, we account for cross-county differences in access to external markets, as captured by distance to waterways and the presence of roads and railways, and in more proximate measures of labor abundance and economic development, such as population density and urbanization rate in the early nineteenth century. It is also important to note that although the latter controls may themselves be endogenous in our regression framework, both population density and urbanization rate are observed in a census that preceded the time horizon over which the outcome variable is measured. As such, while the second-stage coefficients associated with these controls may well be afflicted by omitted variable bias, the fact that 


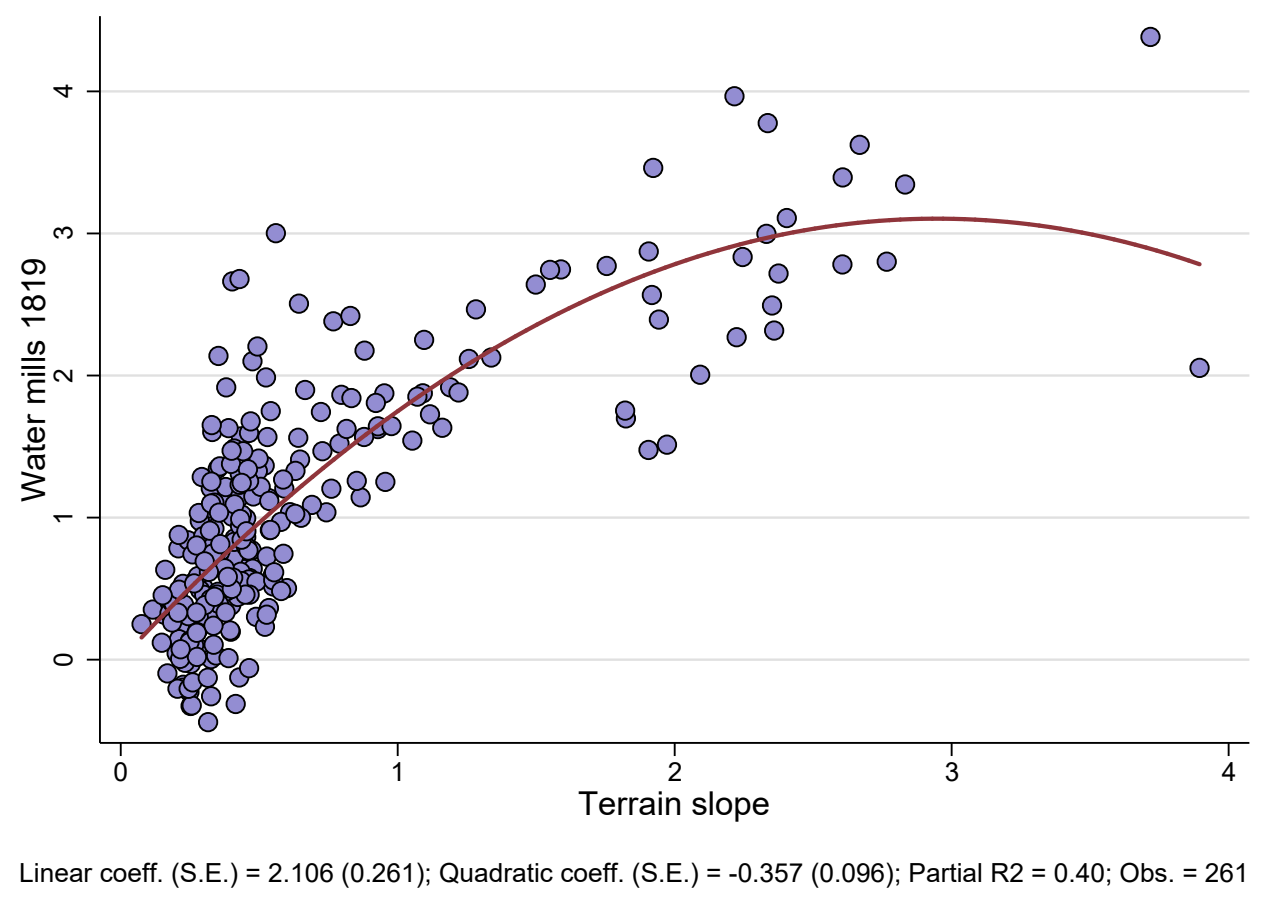

FIGURE 5: Terrain slope and water mills in 1819

Notes. This scatter plot depicts the trade-off associated with the influence of terrain structure on the operability of water mills, illustrating a significant non-monotonic relationship across Prussian counties between the average terrain slope and the number of water mills per 1,000 inhabitants in 1819. The depicted relationship accounts for heterogeneity across counties in potentially confounding geographical factors. See the discussion in the main text and Appendix A for additional details.

they are not marred by reverse causation still makes them useful for excluding mechanisms, broadly pertaining to economic development, through which terrain slope could potentially influence the persistence of coercive labor institutions.

Second, had the terrain slope variable been particularly susceptible to the issue of nonexcludability from the second stage of our framework, one expects that upon augmenting the specification with additional control variables, there would be considerable instability in the 2SLS estimate of our coefficient of interest. In contrast, as will become evident, we find that conditional on all geographical controls, the 2SLS coefficient associated with the prevalence of water mills remains largely stable when additional covariates are included in the estimating equation. Related to this pattern, we also find that the first-stage coefficients reflecting the non-monotonic influence of the average terrain slope on the prevalence of water mills in 1819 remain remarkably stable when additional controls are incorporated in our 2SLS framework. A similar pattern of stability is also observed for the first-stage partial $R^{2}$ that captures the explanatory power of the residual variation in terrain slope for the residual variation in the prevalence of water mills across counties.

Lastly, to the extent that the possible non-excludability of terrain slope from our baseline regressions can manifest itself in a higher 2SLS coefficient estimate for the prevalence of water 
mills, it may be noted that in our full sample of counties and conditional on our complete set of covariates, we actually obtain largely similar estimates in the OLS and 2SLS frameworks. This finding suggests that insofar as our 2SLS approach is able to credibly mitigate the potential issue of omitted variable bias in our original OLS specifications, this bias is inconsequential to begin with.

\subsection{Cross-sectional findings}

\subsubsection{Baseline analysis: Controlling for geographical confounders}

Table 1 reveals the results from estimating our baseline set of regressions, exploiting variations across Prussian counties to link the prevalence of water mills in 1819 with the share of serfs that were de facto emancipated during the 1821-1848 time horizon, conditional on geographical characteristics. In column 1, we report the coefficient estimate for the bivariate relationship between our variables of interest. This estimate is statistically significant at the $1 \%$ level and implies that an increase in the prevalence of water mills in 1819 by one standard deviation is associated with an average increase in the intensity of de facto serf emancipation between 1821 and 1848 by $30 \%$ of a standard deviation of this variable in our sample of 261 counties. The scatter plot in panel (a) of Figure 6 depicts the corresponding bivariate relationship between the unstandardized counterparts of our variables of interest.

In columns 2-7, we augment our bivariate specification from column 1 to account for heterogeneity across counties in each of our geographical covariates at a time - namely, average temperature, average precipitation, distance to navigable rivers, two different measures of soil suitability for agriculture, and an "East Elbia" fixed effect. The results indicate that conditional on the prevalence of water mills in 1819, the geographical factors that individually matter the most for the pace of de facto serf emancipation in the first half of the nineteenth century are temperature, precipitation, and soil suitability for cereal crops, all measured using contemporary high-resolution geospatial data. The significance of the latter two variables potentially reflects the stronger vested interests of the landowning elites in maintaining coercive labor institutions in those locations where, because of the higher agricultural productivity of land (arising from more precipitation and/or better soil quality), the elites could benefit more from the continued use of serf labor in large-scale agricultural production. ${ }^{42}$ On the other hand, the positive and significant coefficient estimate for average temperature likely captures the apparent latitudinal gradient in the intensity of emancipation across Prussian counties, particularly in East Elbia, as is evident from the map in Figure 2.

In terms of the other geographical covariates in columns $2-7$, their associated coefficients are imprecisely estimated, and they do not necessarily enter their respective regressions with expected signs, as is the case for distance to navigable rivers. In line with priors, however, the regression in column 7 suggests that coercive labor institutions were more persistent in the counties located to

\footnotetext{
${ }^{42}$ Our finding that soil suitability for agriculture is associated with greater persistence in coercive labor institutions is in line with those reported by Bobonis and Morrow (2014) and Dippel et al. (2015). Interestingly, our alternative measure of soil suitability for agriculture, which reflects the share of sand in the top soil, does not appear to be significantly associated with the pace of de facto serf emancipation.
} 


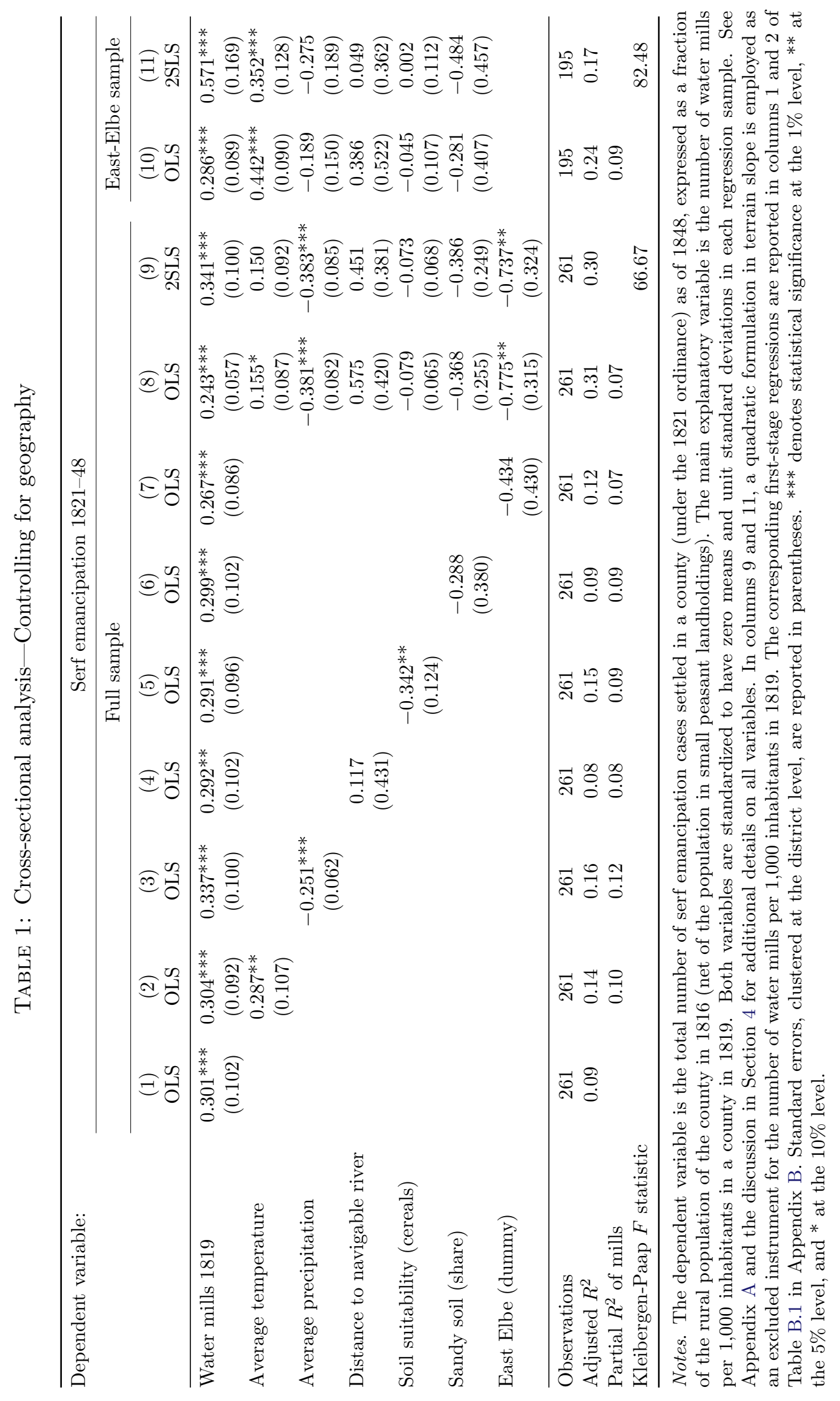




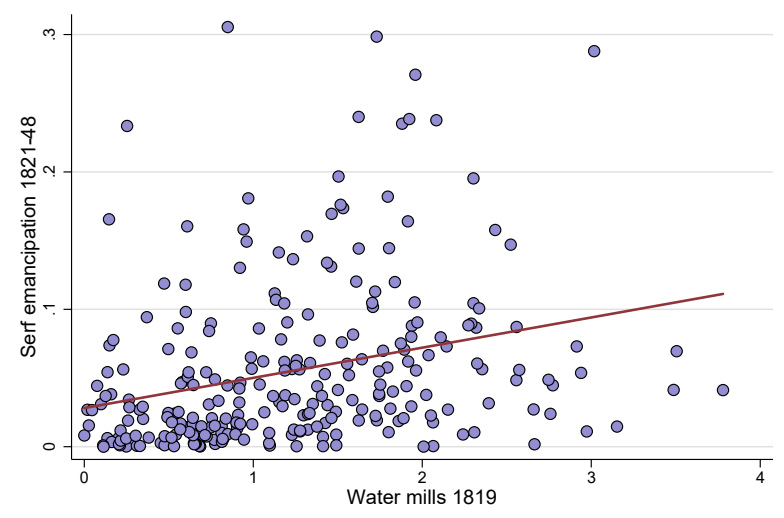

Slope coeff. (S.E.) $=0.022$ (0.008); Adj. R2 = 0.07; Obs. $=260$

(a) Bivariate relationship

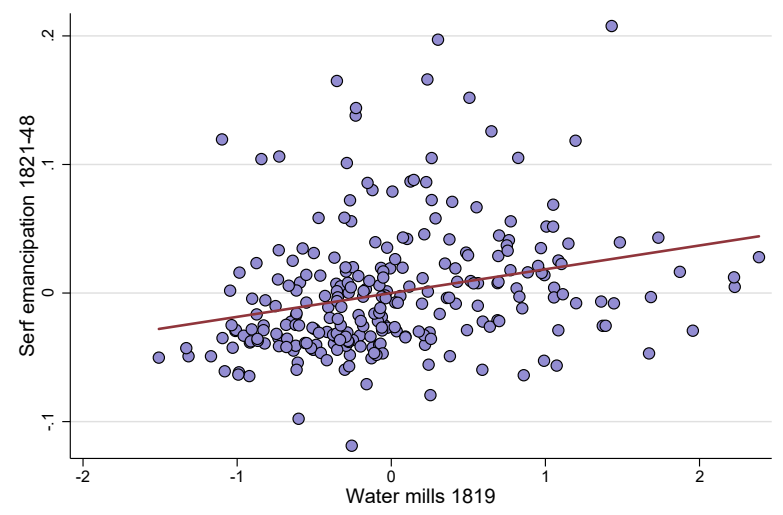

Slope coeff. (S.E.) $=0.019(0.004) ;$ Partial R2 $=0.07$; Obs. $=260$

(b) Conditional on geography

FiguRE 6: Water mills in 1819 and serf emancipation 1821-48

Notes. These scatter plots illustrate the significant positive relationship across Prussian counties between the extent of proto-industrialization, as measured by the number of water mills per 1,000 inhabitants in a county in 1819, and the subsequent intensity of de facto serf emancipation, measured as the total number of serf emancipation cases settled in a county (under the 1821 ordinance) as of 1848, expressed as a fraction of the rural population of the county in 1816 (net of the population in small peasant landholdings). The bivariate relationship between unstandardized variables is depicted in panel (a), whereas panel (b) depicts the relationship after accounting for heterogeneity across counties in potentially confounding geographical factors. For visual clarity, both plots omit a non-influential outlier from the sample of counties. See the discussion in the main text and Appendix A for additional details.

the east of the river Elbe, where both industrialization and serf emancipation are known to have been delayed due to the vested interests of the nobility in the continuation of large-scale agriculture (see, e.g., Harnisch, 1986; Melton, 2000; Acemoglu et al., 2011; Cinnirella and Hornung, 2016a). Nevertheless, in all specifications corresponding to columns 2-7, our coefficient of interest remains both highly statistically significant and quantitatively rather stable, indicating that a unit standard deviation increase in the prevalence of water mills in 1819 is associated with an average increase of between $27 \%$ and $34 \%$ of a standard deviation in the intensity of de facto serf emancipation during the 1821-1848 time horizon.

Controlling simultaneously for all geographical covariates, the specification in column 8 yields an estimate for our coefficient of interest that remains highly statistically significant and is only marginally smaller than the estimates from earlier columns. The corresponding conditional relationship between the unstandardized counterparts of our variables of interest is depicted by the scatter plot in panel (b) of Figure 6. With respect to the geographical covariates, almost all variables enter the regression with their expected signs, although only temperature and precipitation are statistically significant, as is the negative fixed effect associated with counties located in East Elbia. Interestingly, conditional on the prevalence of water mills in 1819 and other geographical factors, the suitability of the soil for cereal crops is no longer statistically significant.

To mitigate potential omitted variable bias in our estimated coefficient of interest from column 8, we consider the same specification under the 2SLS approach in column 9, exploiting the 
non-monotonic influence of terrain slope on the prevalence of water mills in 1819 in the first-stage regression. The estimated 2SLS coefficient of interest suggests a more pronounced relationship between the prevalence of water mills in 1819 and the subsequent intensity of de facto serf emancipation. This result could partly be a reflection of attenuation bias in our coefficient of interest under OLS estimation, since the prevalence of water mills in 1819 is only a noisy proxy of the true but unobserved measure of the elites' incentives to emancipate their serfs and subsequently employ them in capital-intensive production activities. Another possibility is that our set of covariates considered thus far is not quite sufficient to ensure the conditional excludability of terrain slope from a regression explaining the de facto decline in serfdom. Indeed, as will become evident shortly, once our specification is augmented to account for additional potential confounders, the estimated conditional relationship of interest is almost identical under OLS and 2SLS estimation frameworks.

Meanwhile, it may be noted that the remarkably high first-stage $F$ statistic reported in column 9 precludes any potential weak-instrument issues. This assertion is further corroborated by the results from the corresponding first-stage regression (reported in column 1 of Table B.1 in Appendix B), which shows highly significant coefficients associated with the linear and quadratic terms of terrain slope, conditional on our set of geographical covariates. This regression is also characterized by a sizable partial $R^{2}$ relative to the overall $R^{2}$, reflecting the considerable explanatory power of the residual cross-county variation in terrain slope for the residual variation in the prevalence of water mills in 1819. Furthermore, as is evident from the remaining columns of Table B.1, the coefficients reflecting the non-monotonic influence of terrain slope on the prevalence of water

mills (and, to a lesser extent, the partial explanatory power of terrain slope) remain quantitatively stable when our 2SLS framework incorporates additional control variables.

Finally, in columns 10 and 11 of Table 1, we estimate the specifications examined in the preceding two columns, focusing exclusively on the sub-sample of counties located in East Elbia. Although our full-sample analysis does account for differences in cross-county means between regions in the west versus east of the river Elbe, the presence of this fixed effect alone is insufficient to claim that the positive reduced-form association between the extent of proto-industrialization and the intensity of de facto serf emancipation actually held under the different institutional conditions in regions east of the river Elbe. Reassuringly, based on variations exclusively across counties in East Elbia, the regression estimates reported in columns 10 and 11 document reduced-form empirical patterns that are qualitatively similar to and, if anything, quantitatively even stronger than those observed in our full sample of counties.

\subsubsection{Augmented analysis: Controlling for proximate confounders}

Our analysis of the reduced-form relationship between the prevalence of water mills in 1819 and the subsequent pace of de facto serf emancipation has thus far only considered exogenous geographical covariates. We now augment our analysis to additionally account for less exogenous but more proximate potential confounders of this relationship, such as the initial levels of economic development, labor abundance, access to urban markets, and the intensity of human capital investments as well 
as various demographic, cultural, and institutional characteristics. Although the endogeneity of these proximate confounders (as well as those considered in the next section) precludes a causal interpretation of their associated coefficients in our regressions, our intention is to simply assess the extent to which these additional covariates can explain away the relationship of interest, conditional on our full set of geographical controls. The estimation results for our augmented specifications are collected in Table 2. As in the preceding analysis, we initially introduce additional controls one at a time, before including them all simultaneously. To highlight the key result from this exercise, we find that the strong positive association between the extent of proto-industrialization and the subsequent intensity of labor emancipation remains not only qualitatively unaffected but also largely stable and highly statistically significant across specifications, as is evident from the top row of Table 2 .

In columns 1 and 2, we present the estimates from regressions that include, respectively, population density and the urbanization rate in 1816 as additional covariates. These factors partly account for the initial level of economic development (or even the initial extent of industrialization, as reflected by the urbanization rate) as well as theories of emancipation that emphasize the role of either labor abundance or the perceived threat of labor scarcity arising from better outside options for serfs (e.g., Postan, 1966; Domar, 1970; Brenner, 1976; Acemoglu and Wolitzky, 2011). ${ }^{43}$ Although both covariates enter their respective regressions with positive coefficients, the one associated with initial population density is imprecisely estimated. Moreover, as shown in column 9, in the specification including the full set of covariates, urbanization rate continues to retain a significant positive relationship with the subsequent decline in coercive labor institutions, whereas the coefficient estimate on population density changes its sign and remains statistically insignificant. Thus, while our prima facie evidence regarding the influence of labor abundance (as captured by population density) on emancipation is mixed, the findings suggest that the threat of labor scarcity in agriculture due to better options for workers in urban markets (as captured by the urbanization rate) may well have played an important role in the decline of coercive labor institutions in nineteenth-century Prussia.

The specification in column 3 aims to account for the fact that because an emancipation settlement typically involved an entire peasant family rather than an individual serf, larger peasant family sizes could have been associated with higher redemption costs (and, thus, the reduced ability of peasant families to actually pay for their redemption), reflecting higher amounts of servile dues per family to the manorial lords. In addition, since our outcome variable normalizes the number of emancipation cases settled in a county as of 1848 by the initial rural population of the county, it is expected to be mechanically negatively associated with the average size of peasant families. Moreover, smaller family sizes could be reflective of higher levels of industrial demand

\footnotetext{
${ }^{43}$ Lagerlöf (2016) provides a nuanced interpretation of the influence of labor scarcity on the prevalence of coercive labor institutions, arguing that when free workers migrate from rural to urban areas to match with better outside options, rural elites can counteract the resulting labor scarcity in the long run by temporarily increasing the well-being of coerced workers to engender a Malthusian fertility response, which ultimately increases the supply of coerced labor (and their representation in the rural population) given the hereditary transmission of labor status.
} 


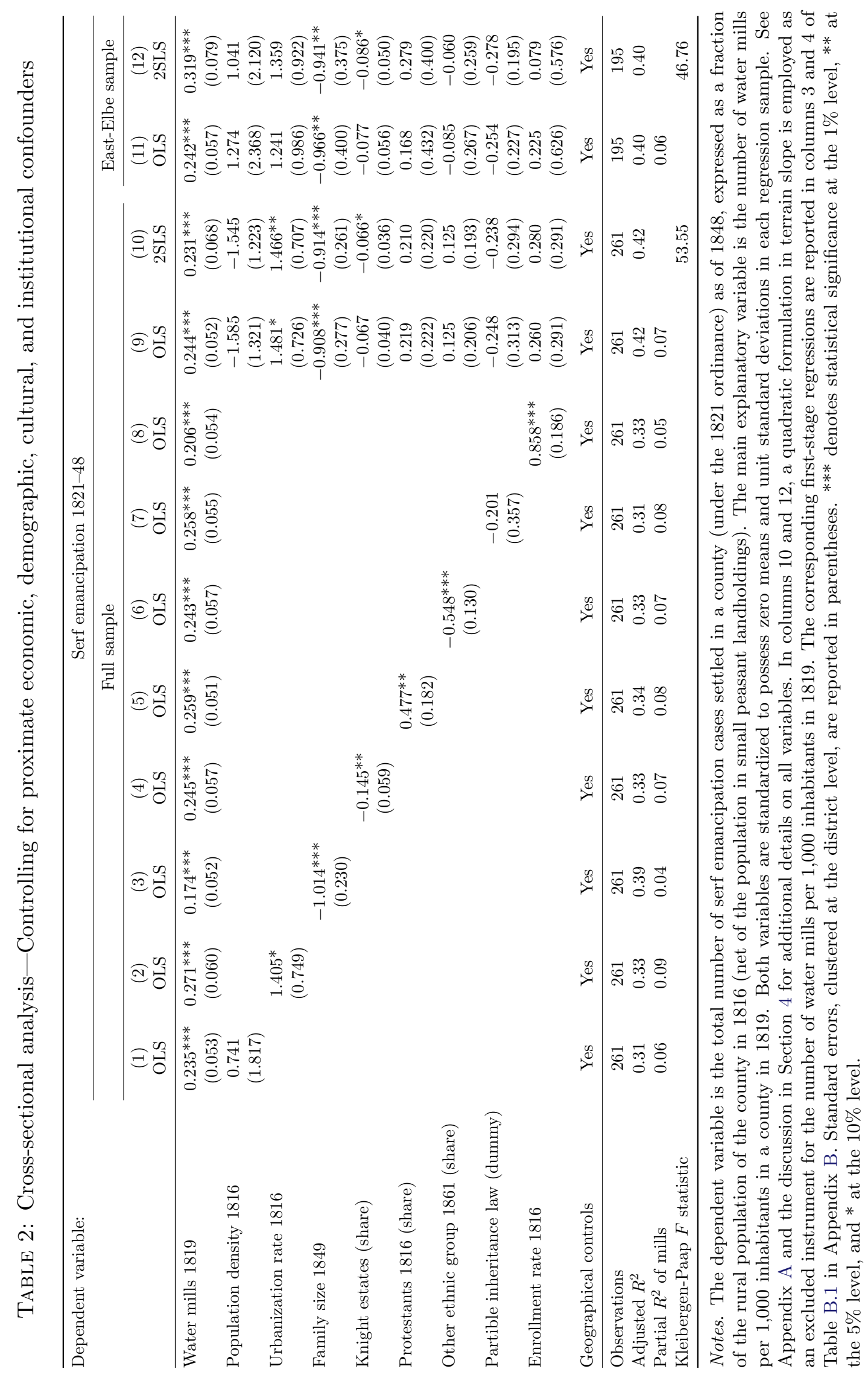


for human capital and, thus, more intense shifts of households away from child quantity towards child quality, as suggested by human-capital-driven theories of the demographic transition (see, e.g., Galor, 2011). ${ }^{44}$ The estimation results in columns 3 and 9 indicate that average family size is indeed negatively and significantly associated with the pace of de facto serf emancipation. ${ }^{45}$

The regression presented in column 4 directly accounts for stronger vested interests of the landlords in maintaining coercive labor institutions in agriculture, by including the share of knight estates (Rittergüter) in a county as a proxy measure of landownership concentration amongst the elites. ${ }^{46}$ These large manorial estates are known to have relied heavily on the intensive appropriation of serf labor for large-scale agriculture (Cinnirella and Hornung, 2016a), especially in counties east of the river Elbe. In line with priors, the covariate enters the regression in column 4 with a negative and statistically significant coefficient, although its magnitude is diminished when the full set of covariates is accounted for by the specification in column 9 .

In columns 5 and 6 , we control for differences across county populations in their religious and ethnic compositions - as captured by the share of Protestants in 1816 or the share of individuals of non-Germanic (mostly Slavic) ancestry in 1861 - that could have affected the pace of de facto labor emancipation, the onset of industrialization, or even the propensity to attract migrant groups from various ethnic backgrounds. In line with the connection between Protestantism and early human capital formation (Becker and Woessmann, 2009), the regression in column 5 indicates that the prevalence of Protestantism in 1816 may well have contributed to the subsequent pace of labor emancipation. Furthermore, the share of the non-Germanic population in a county enters the regression in column 6 with a significant negative coefficient, plausibly reflecting the fact that the prevalence of individuals with Slavic (Polish) ancestry was higher in counties belonging to the province of Posen, where coercive labor institutions were historically more persistent. The estimated coefficients associated with both religious and ethnic composition, however, become statistically insignificant in the fully specified regression model of column 9 .

The regression in column 7 introduces an indicator for the predominant law of succession of peasant landholdings in a county (namely, partible inheritance versus primogeniture) as a covariate. On the one hand, the historical association between primogeniture and the prevalence of large-scale agriculture potentially implies a delayed emancipation process in regions that practiced this form of inheritance. On the other hand, because partible inheritance mechanically resulted in the increased prevalence of small peasant landholdings that were de jure excluded from the emancipation process until the passage of the Commutation Law of 1850, one expects lower rates of emancipation in

\footnotetext{
${ }^{44}$ See also Becker et al. $(2010,2012)$ for evidence showing the existence of a negative effect of educational investments on fertility, both prior to and during the onset of the demographic transition in nineteenth-century Prussia.

${ }^{45}$ The earliest year for which county-level data on average family size are available is 1849 . Because this date occurs towards the end of the time horizon over which our emancipation outcome is observed, the estimated coefficients associated with family size may well be marred by reverse causality. Indeed, Cinnirella and Hornung (2016b) provide evidence of changes in patterns of education and fertility that may have occurred in response to the Prussian emancipation process over the course of the nineteenth century.

${ }^{46}$ Although our measure of the share of knight estates is based on data for 1856, as discussed by Cinnirella and Hornung (2016a), the historical evidence suggests that this share remained largely unchanged throughout the period under consideration.
} 
regions that practiced divided succession. Consistently with the dominance of the latter effect, the indicator for partible land inheritance appears to be negatively associated with the share of serfs emancipated by 1848 in the specifications examined in columns 7 and 9, although this relationship is not precisely estimated.

In column 8, we directly account for heterogeneity across counties in the initial intensity of investments in human capital, as captured by the enrollment rate in public primary schools in 1816, which could have conditioned the propensity of the capital-owning elites to subsequently emancipate the peasantry while also affecting the pace of industrialization. Perhaps unsurprisingly, the regression in column 8 suggests that the primary school enrollment rate in 1816 is positively and significantly associated with the prevalence of de facto emancipated serfs as of 1848, although the estimated relationship becomes weaker and loses statistical significance when conditioned on the full set of covariates in column 9 .

Columns 9 and 10 reveal the estimation results for specifications including the complete set of controls for proximate confounders, first under OLS and then employing our 2SLS strategy, in the full sample of counties. Notably, the OLS estimate of our coefficient of interest is virtually identical to that obtained in column 8 of Table 1, when only geographical covariates were taken into account. In addition, the OLS and 2SLS coefficient estimates are now very similar, suggesting that conditional on the credibility of our 2SLS framework, any residual omitted variable bias potentially afflicting the OLS estimate of our coefficient of interest is negligible.

Last but not least, in columns 11 and 12, we replicate the analysis from the preceding two columns but focusing exclusively on the sub-sample of counties in East Elbia. The analysis reassuringly yields an OLS estimate of the relevant relationship that is almost identical to that found in the full sample of counties in column 9. Furthermore, although the corresponding point estimate under 2SLS is somewhat larger than its OLS counterpart, this gap is substantially smaller than the one observed earlier in Table 1, when our analysis included only geographical covariates.

\subsubsection{Augmented analysis: Additional robustness checks}

The analysis presented in Table 3 accounts for further potential confounders of the positive reducedform relationship between the prevalence of water mills in 1819 and the intensity of de facto serf emancipation during the 1821-1848 time horizon, conditional on all the covariates considered thus far. As highlighted by the top row of Table 3, our main finding is that the coefficient of interest remains both highly statistically significant and largely stable in magnitude across specifications for our full sample of counties, relative to its baseline estimate from column 9 of Table 2 .

The specification in column 1 accounts for cross-county heterogeneity in the prevailing intensity of labor coercion, as proxied by the average amount of servile labor dues redeemed by former serfs (through compensation payments to their manorial lords) across the emancipation cases settled in a county as of 1848 . Although the coefficient associated with this covariate is imprecisely estimated in the regressions of both column 1 and the fully specified model of column 8 , it does carry the expected negative sign, potentially reflecting both a diminished ability of the peasantry 
to make the necessary compensation payments and stronger economic incentives of the landlords to prolong the employment of serf labor when the intensity of coercion is already high.

In columns 2 and 3, we introduce dummy variables indicating, respectively, the presence of a main road and a railway line in 1848. In addition to the initial urbanization rate, these covariates plausibly capture the extent to which a county's rural locales were integrated with external goods and factor markets. Market integration could have affected not only the process of labor emancipation, by facilitating access to better outside options for the peasantry and, thereby, increasing their bargaining power against the elites, but also the extent and pace of industrialization, through the standard Smithian mechanism of economic development. ${ }^{47}$ The results presented in columns 2 and 3 suggest that although the presence of a main road is not statistically significantly related with serf emancipation, access to railways may indeed have played an important role in accelerating the decline of serfdom in Prussia. These findings continue to hold qualitatively in the fully specified model of column 8 .

The literature on Prussian industrialization during the latter half of the nineteenth century has emphasized access to coal deposits as an important determinant of not only the pace of industrialization but also the spatial distribution of industrial activities due to agglomeration effects (e.g., Pierenkemper, 1978; Kiesewetter, 2004; Gutberlet, 2014). Although coal mining in Prussia did not take off until circa 1850 and remained under state control until 1865, its emergence may nevertheless have created new labor-market opportunities for the peasantry, thus contributing to the likelihood of their de facto emancipation by increasing the perceived threat of labor scarcity in agriculture, at least towards the end of the time period over which our outcome variable is measured. In addition, the presence of coal deposits could be correlated with features of the local terrain (like elevation) that may have influenced the spatial distribution of water mills even in the early nineteenth century, posing a potential threat to the exclusion restriction in our 2SLS framework. The specification in column 4 thus examines the extent to which our coefficient of interest is affected by controlling for an indicator of the historical presence of a coalfield in a county, based on geospatial data from Fernihough and O'Rourke (2014). The indicator enters the regressions with an expected positive coefficient, in both column 4 and the fully specified model of column 8 , although its point estimates are statistically insignificant.

The specification in column 5 controls for the number of social uprisings that occurred in a county during the 1816-1847 time period, aiming to capture differences across counties in the strategic incentives of the elites to relinquish their coercive economic power when faced with a credible threat of social unrest and mass appropriation of elite assets (Acemoglu and Robinson, 2000; Aidt and Franck, 2015). Such strategic incentives could have been stronger when the elites had more to lose from mass appropriation (i.e., in those counties where their ownership of capital and land was higher) or perhaps weaker, given that wealthier elites could devote more resources to the suppression of popular revolts. The regression results presented in both columns 5 and 8 indicate

\footnotetext{
${ }^{47}$ Indeed, Hornung (2015) provides evidence that causally links railway access to urban population growth in nineteenth-century Prussia.
} 


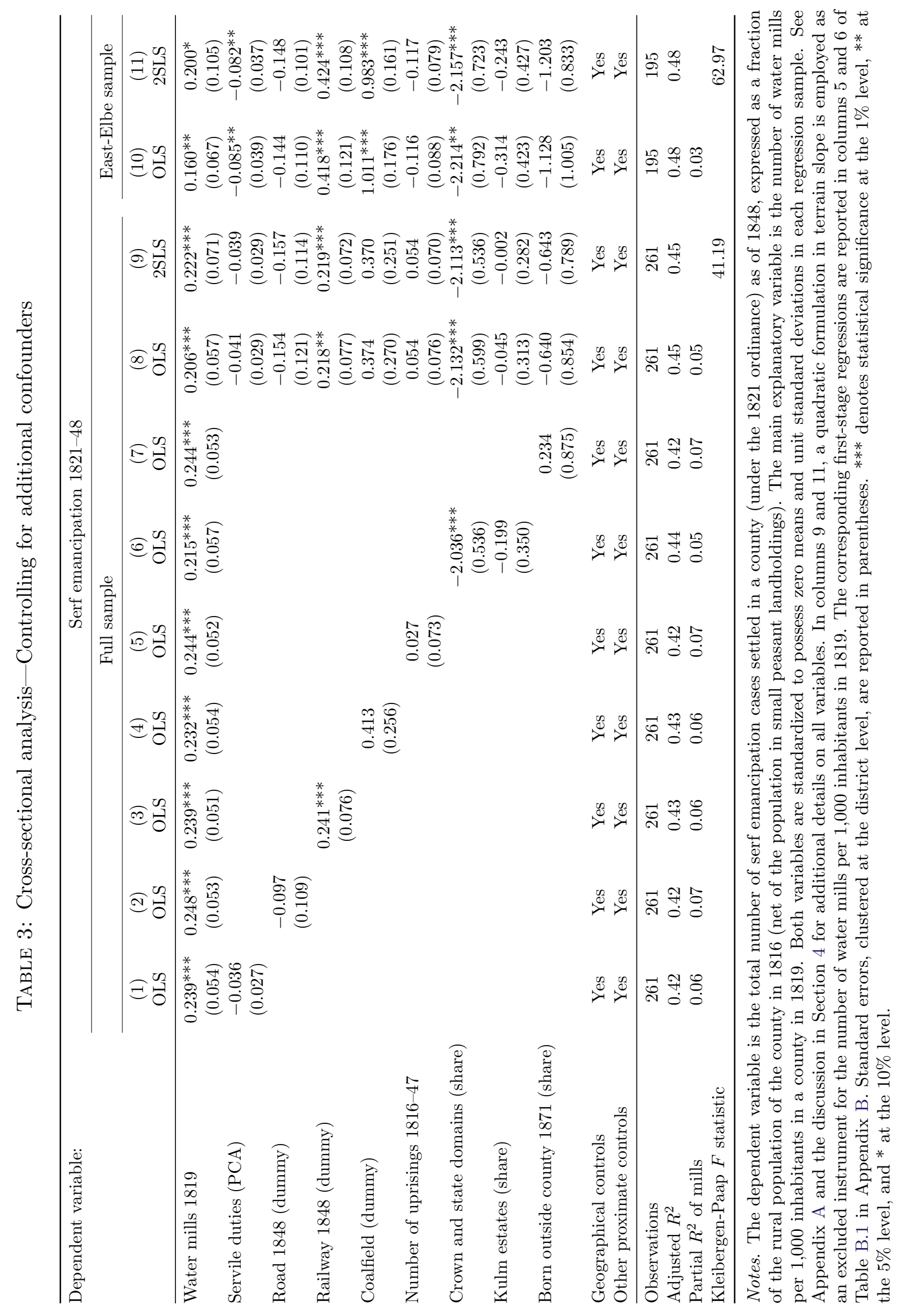


that the number of social uprisings is in fact positively associated with the decline in serfdom, although the relationship is not precisely estimated. This association, however, hardly explains our key positive relationship between the prevalence of water mills in 1819 and the subsequent rate of serf emancipation. ${ }^{48}$ Consistently with this robustness result, Figure B.1 in Appendix B shows the absence of any systematic relationship across counties between either the prevalence of water mills or the share of knight estates, on the one hand, and the number of social uprisings, on the other. These findings suggest that the threat of mass revolts was not necessarily higher (or lower) in counties where the elites may have owned more assets, thus making it unlikely that wealthier elites harbored characteristically different strategic motives to emancipate the local peasantry.

In column 6, we take into account the potentially confounding influence of the initial availability of free peasants, which could have diluted the economic incentive to emancipate the enserfed population (e.g., if the elites initially allocated the available free labor to industrial production activities). Further, because counties with a larger initial share of free peasants had smaller enserfed populations to begin with, they are mechanically expected to have converged less rapidly to a state to full emancipation. As explained in Section 4.3, we employ two historically relevant proxy measures of the initial availability of free peasants at the county level: the share of landholdings owned by the Prussian Crown and/or the state and the share of manorial estates that operated under the so-called Kulm law. The results shown in column 6 indicate that, as expected, both measures are negatively related with the share of serfs emancipated by 1848, although only the coefficient associated with the share of Crown and state domains is statistically significant. Moreover, the same empirical patterns continue to hold with respect to these covariates in the fully specified model of column 8.

As discussed in Section 3.2, the historical narrative of the Prussian labor emancipation process indicates that even upon redeeming their lifetime servile dues, many peasants continued to work for their former lords as free laborers, thus suggesting a relatively high degree of segmentation across labor markets. In addition, ex ante awareness amongst the elites of such segmentation may have been important; otherwise, even if they became aware that supporting labor emancipation would complement their increasing investments in industrial activities, the possibility that their workers, upon gaining freedom, could seek superior employment opportunities elsewhere would have discouraged (or prevented) the elites from acting upon their economic incentive to emancipate. Figure 7 provides prima facie empirical evidence suggesting not only that labor markets were highly segmented across Prussian counties in the early nineteenth century but also that the intensity of de facto serf emancipation was unrelated to the potential threat of local labor scarcity, arising from the possibility that liberated serfs could have attempted to exploit better options elsewhere as free laborers.

In line with the non-convergence of prices across weakly integrated factor markets, the scatter plot in panel (a) of Figure 7 documents considerable heterogeneity across counties in the

\footnotetext{
${ }^{48}$ This robustness result is insensitive to using alternative measures of social unrest at the county level, including either the total number of days of protests or a dummy variable indicating if there was ever a protest in a county during the 1816-1847 time period.
} 


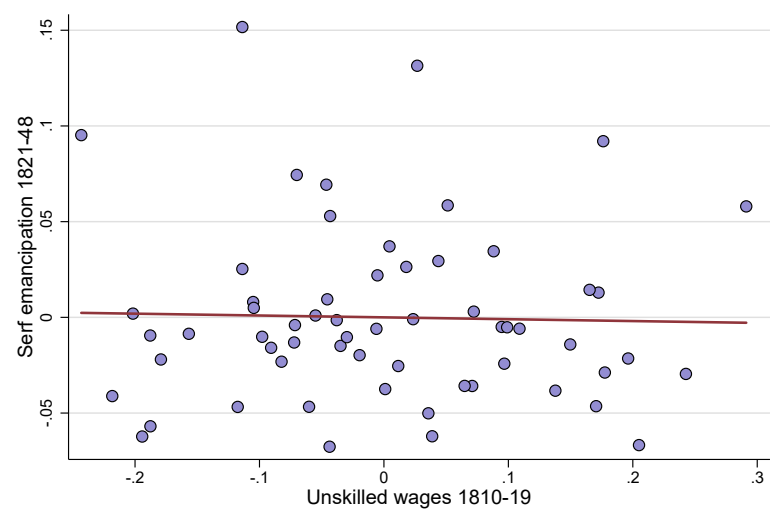

Slope coeff. (S.E.) $=-0.010(0.061)$; Partial R2 $=0.00 ;$ Obs. $=60$

(a) Unskilled wages and subsequent serf emancipation

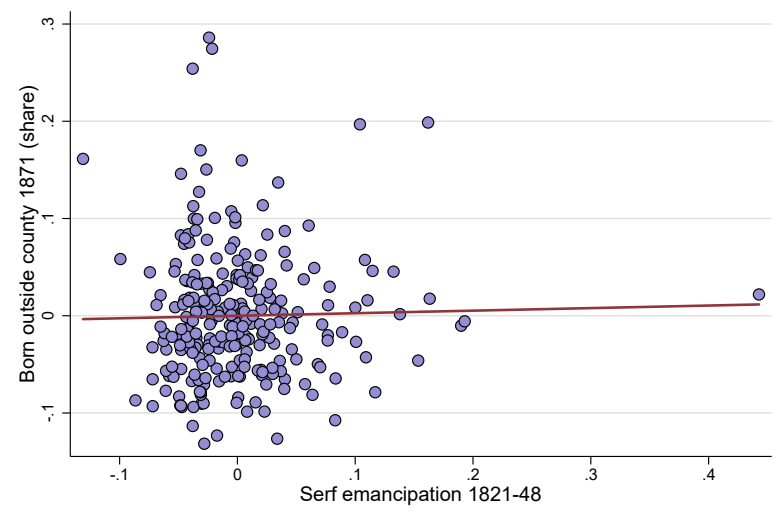

Slope coeff. (S.E.) $=0.026(0.085)$; Partial R2 $=0.00$; Obs. $=261$

(b) Serf emancipation and labor migration

FiguRE 7: Unskilled wages, serf emancipation, and labor migration

Notes. The scatter plot in panel (a) documents, consistently with segmented labor markets, significant variation in the average unskilled wage rate across Prussian counties in the early nineteenth century. It also illustrates that this variation is uncorrelated with the variation in the subsequent intensity of de facto serf emancipation. The scatter plot in panel (b) illustrates the absence of any systematic relationship across Prussian counties between the prevalence of de facto serf emancipation as of 1848 and labor migration flows, as measured by the share of a county's population in 1871 that was born outside the county. Both plots depict relationships that account for heterogeneity across counties in potentially confounding geographical factors. The sample of counties in panel (a) is constrained by the availability of county-level data on unskilled wages in the early nineteenth century. See the discussion in the main text and Appendix A for additional details.

average wage rate of unskilled day laborers during the 1810-1819 time period, conditional on geographical covariates. It further shows that this residual variation in wages bears no systematic relationship with the residual variation in the share of serfs emancipated during the 1821-1848 time horizon. This finding suggests that the threat of migration-driven local labor scarcity did not influence the elites' decision to either delay or accelerate the emancipation process and, moreover, that serfs were not necessarily able to exploit higher wages by working as day laborers in order to expedite the redemption of their lifetime servile dues via higher compensation payments to the landlords. Further, the scatter plot in panel (b) of Figure 7 shows that the intensity of immigration flows over the relevant time period, proxied by the share of a county's population in 1871 that was born outside the county, was largely unrelated to the pace of the emancipation process, conditional on cross-county heterogeneity in geographical factors. This pattern is further confirmed by the regression results presented in column 7 of Table 3. Specifically, although the "born outside county" population share in 1871 enters the regression with a positive coefficient, the relationship is not statistically distinguishable from zero, and it hardly affects our primary coefficient of interest.

Finally, in columns 8-11, we present the results from estimating specifications that simultaneously include all the additional potential confounders, first under OLS and then applying our 2SLS framework, for either the full sample of counties or the sub-sample of counties located in East Elbia. In the regressions based on the full sample, the OLS and 2SLS point estimates of our coefficient of interest continue to remain largely similar to one another, and reassuringly, they 
TABLE 4: Cross-sectional analysis-Explaining the cost of redemption

\begin{tabular}{lcccc}
\hline Dependent variable: & \multicolumn{4}{c}{ Redemption costs $(\mathrm{PCA})$} \\
\cline { 2 - 5 } & $(1)$ & $(2)$ & $(3)$ & $(4)$ \\
& OLS & OLS & OLS & 2SLS \\
\hline Water mills 1819 & $-0.232^{* *}$ & $-0.087^{* *}$ & $-0.093^{* *}$ & $-0.161^{* *}$ \\
Servile duties (PCA) & $(0.089)$ & $(0.041)$ & $(0.040)$ & $(0.077)$ \\
& & $0.554^{*}$ & $0.583^{*}$ & $0.568^{*}$ \\
Geographical controls & & $(0.291)$ & $(0.300)$ & $(0.297)$ \\
\hline Observations & No & No & Yes & Yes \\
Adjusted $R^{2}$ & 261 & 261 & 261 & 261 \\
Partial $R^{2}$ of mills & 0.05 & 0.33 & 0.39 & 0.39 \\
Kleibergen-Paap $F$ statistic & & 0.01 & 0.01 & 65.21 \\
\hline
\end{tabular}

Notes. The dependent variable is the first principal component of four different types of total compensation payments made by serfs to the landlords (across all emancipation cases settled by 1848 under the 1821 ordinance) for the redemption of lifetime servile duties in a county, expressed as a fraction of the number of settled cases. The main explanatory variable is the number of water mills per 1,000 inhabitants in a county in 1819. Both variables are standardized to possess zero means and unit standard deviations. See Appendix A and the discussion in Section 4 for additional details on all variables. In column 4, a quadratic formulation in terrain slope is employed as an excluded instrument for the number of water mills per 1,000 inhabitants in 1819. The corresponding first-stage regression is reported in column 7 of Table B.1 in Appendix B. Standard errors, clustered at the district level, are reported in parentheses. ${ }^{* * *}$ denotes statistical significance at the $1 \%$ level, $* *$ at the $5 \%$ level, and $*$ at the $10 \%$ level.

are both only marginally smaller than their respective counterparts presented in columns 9 and 10 of Table 2. On the other hand, although the relevant OLS and 2SLS point estimates for the East Elbian sub-sample are somewhat more noticeably attenuated in comparison to their respective counterparts from columns 11 and 12 of Table 2, they continue to remain statistically and economically significant, and the gap between OLS and 2SLS estimates is appreciably smaller than before.

\subsubsection{Explaining redemption costs}

Thus far, our empirical analysis has focused on establishing a robust and significant positive reduced-form link between early industrialization, as proxied by the prevalence of water mills in 1819, and the subsequent intensity of serf emancipation at the county level. In this section, we provide some corroborating evidence regarding a possible mechanism underlying this reduced-form link. In particular, our conceptual framework suggests that, ceteris paribus, elites with greater stakes in the ownership of physical capital should have been more willing to hasten the process of labor emancipation by settling for lower compensation payments from their serfs for the redemption of lifetime servile dues.

Table 4 reveals the results of regressions aimed at exploring this mechanism, linking the prevalence of water mills in 1819 with the cost of redemption, based on the average compensation 
payments made to the landlords across emancipation cases settled between 1821 and 1848 . The bivariate regression presented in column 1 indicates, in line with our framework, a statistically significant negative association between the two variables.

Because our data on the cost of redemption associated with a settled emancipation case reflects the overall compensation payment to the manorial lord, rather than the negotiated price per unit of servile dues redeemed, the outcome variable is expected to be mechanically positively correlated with the amount of servile dues in the redemption agreement. The specification in column 2 thus introduces the previously discussed measure of average coercion intensity across the settled emancipation cases in a county as a control variable, finding its expected positive association with the average cost of redemption. Although the introduction of this covariate noticeably attenuates our relationship of interest, the estimated coefficient associated with the prevalence of water mills retains its expected negative sign and remains statistically significant.

The regression in column 3 additionally controls for our full set of geographical covariates. Relative to its estimate from column 2, our coefficient of interest is hardly affected, and it implies that an increase in the prevalence of water mills in 1819 by one standard deviation is associated with a decrease in the average cost of redemption across emancipation cases settled between 1821 and 1848 by $9 \%$ of a standard deviation of the latter variable in our full sample of counties. Finally, in column 4, we estimate the specification from column 3 using our 2SLS framework, finding a somewhat stronger negative association between the prevalence of water mills and the average cost of redemption.

\subsection{Flexible panel analysis}

In this section, we complement the reduced-form cross-county analysis presented above by providing additional evidence based on both cross-sectional and temporal variations over the second half of the nineteenth century at the district level, which represents a higher level of administrative division than counties. Specifically, we exploit information on the annual number of de facto emancipation cases settled in each of 19 districts during the 1850-1898 time horizon to estimate the following flexible panel model (and less stringent variants thereof) using OLS:

Emancipation $_{i, t}=\alpha_{i}+\gamma_{t}+\sum_{\tau=1850}^{1890} \beta_{\tau} \cdot \operatorname{Mills}_{i, 1819} \cdot \gamma_{\tau}+\sum_{\tau=1850}^{1895} \mathbf{X}_{i, \tau}^{\prime} \cdot \boldsymbol{\Lambda}_{\tau} \cdot \gamma_{\tau}+\sum_{\tau=1850}^{1890} \mathbf{Z}_{i}^{\prime} \cdot \boldsymbol{\Omega}_{\tau} \cdot \gamma_{\tau}+\eta_{i, t}$,

where Emancipation $_{i, t}$ is the natural log of the average annual number of emancipation cases settled in district $i$ during a 5 -year period (i.e., 1850-1854, 1855-1859, . ., 1895-1898) indexed by the period's initial year $t ; \alpha_{i}$ and $\gamma_{t}$ are, respectively, time-invariant district and sample-wide period fixed effects; Mills $_{i, 1819}$ is the number of water mills per 1,000 inhabitants in district $i$ in 1819 (i.e., our previous county-level measure aggregated up to the district level); $\mathbf{X}_{i, \tau}$ is a vector of timevarying covariates, including the population size of district $i$ in the initial year of period $\tau$ and the 
number of social uprisings that occurred in district $i$ during period $\tau-5 ; \mathbf{Z}_{i}$ is a vector containing province and East Elbia fixed effects; and $\eta_{i, t}$ is a district-period-specific disturbance term. ${ }^{49}$

Although our proxy measure of early capital-ownership by the elites is itself time-invariant at the district level, by interacting the measure with period dummies, our specification allows us to estimate - via the $\beta_{\tau}$ coefficients - how the cross-sectional relationship between the prevalence of water mills in 1819 and the subsequent flow of labor emancipation evolved over the course of the latter half of the nineteenth century, while accounting for both unobserved heterogeneity in timeinvariant characteristics across districts and period-specific Prussia-wide shocks to the emancipation process. In addition, the interaction of the time-varying covariates with period dummies permits us to control for the possibility that the potentially confounding influences of these covariates could themselves be changing over time. Finally, by interacting the province and East Elbia fixed effects with period dummies, we are able to account, respectively, for differential trends in the emancipation process across provinces and between regions located to the east versus west of the river Elbe.

Table 5 reveals the results from estimating different variants of our flexible panel model. In column 1, we present the results from our simplest specification that controls for only period fixed effects, thus amounting to a repeated cross-district analysis of the association between the prevalence of water mills in 1819 and emancipation flows in the different 5-year time periods. Our baseline results are presented in column 2 , which shows the estimated $\beta_{\tau}$ coefficients from a model that accounts for both district and period fixed effects but does not include any further controls. The coefficients of interest are to be interpreted with respect to the omitted (reference) category, captured by the interaction between the prevalence of water mills in 1819 and the period dummy for 1895-1898. The results indicate that consistently with our earlier findings at the county level, districts exhibiting a higher prevalence of water mills in 1819 also experienced a larger flow of serf emancipation in the mid-nineteenth century. Specifically, the estimate for the 1850-1855 time period indicates that, relative to the reference period, a one standard deviation increase across districts in the prevalence of water mills in 1819 is associated with an $81.2 \%$ increase in the flow of new emancipation cases settled during this first 5-year period in our sample horizon. Thereafter, this significant relationship tends to become quantitatively even more pronounced, achieving its peak with respect to emancipation flows in the 1870-1874 time period, before weakening and turning negative (and even statistically significant) towards the end of our sample horizon in the 1890s. This late reversal is entirely consistent with our earlier findings as it reflects the fact that districts with a larger initial prevalence of water mills experienced a more rapid convergence to a state of full emancipation, and they were therefore already associated with substantially fewer new emancipation cases before the end of our sample horizon. More generally, in light of the inclusion of district fixed effects in the current analysis, the results uncovered here suggest that our previous

\footnotetext{
${ }^{49} \mathrm{~A}$ province is the administrative unit above a district (our sample of 19 districts spans 7 provinces). Further, because our sample horizon ends in 1898, the measurement of time-varying covariates for the last period is based on annual data for four rather than five years. The set of time-varying covariates included in our model is constrained by data availability at the relevant time frequency.
} 
TABLE 5: Flexible panel analysis

\begin{tabular}{|c|c|c|c|c|c|c|}
\hline \multirow{2}{*}{$\begin{array}{l}\text { Dependent variable: } \\
\text { Specification: }\end{array}$} & \multicolumn{6}{|c|}{ Log emancipation cases } \\
\hline & Time FE & Baseline & Population & Uprisings & East Elbe & Province \\
\hline & $(1)$ & $(2)$ & (3) & (4) & $(5)$ & (6) \\
\hline & OLS & OLS & OLS & OLS & OLS & OLS \\
\hline \multirow[t]{2}{*}{ Water mills $1819 \times 1850$} & $0.658^{* *}$ & $0.812^{*}$ & $0.782^{* *}$ & $0.755^{* * *}$ & $0.832^{* * *}$ & $0.479^{*}$ \\
\hline & $(0.281)$ & $(0.414)$ & $(0.326)$ & $(0.258)$ & $(0.270)$ & $(0.263)$ \\
\hline \multirow[t]{2}{*}{ Water mills $1819 \times 1855$} & $0.677^{* * *}$ & $0.832^{* *}$ & $0.823^{* *}$ & $0.778^{* * *}$ & $0.827 * * *$ & $0.389^{*}$ \\
\hline & $(0.169)$ & $(0.312)$ & $(0.292)$ & $(0.263)$ & $(0.283)$ & $(0.203)$ \\
\hline \multirow[t]{2}{*}{ Water mills $1819 \times 1860$} & $0.410^{* * *}$ & $0.565^{*}$ & $0.566^{* *}$ & $0.550^{* *}$ & $0.524^{* *}$ & 0.192 \\
\hline & $(0.121)$ & $(0.278)$ & $(0.268)$ & $(0.241)$ & $(0.247)$ & $(0.204)$ \\
\hline \multirow[t]{2}{*}{ Water mills $1819 \times 1865$} & $0.802^{* *}$ & $0.957^{*}$ & $0.963^{* * *}$ & $0.993^{* * *}$ & $1.124^{* * *}$ & 0.164 \\
\hline & $(0.352)$ & $(0.473)$ & $(0.334)$ & $(0.313)$ & $(0.313)$ & $(0.216)$ \\
\hline \multirow{2}{*}{ Water mills $1819 \times 1870$} & $0.874^{* * *}$ & $1.029 * * *$ & $1.028^{* * *}$ & $0.996^{* * *}$ & $1.083^{* * *}$ & $0.718^{* * *}$ \\
\hline & $(0.209)$ & $(0.303)$ & $(0.245)$ & $(0.224)$ & $(0.245)$ & $(0.230)$ \\
\hline \multirow{2}{*}{ Water mills $1819 \times 1875$} & $0.287^{*}$ & $0.442^{*}$ & $0.437^{*}$ & $0.544^{* *}$ & $0.601^{* *}$ & $0.630^{* * *}$ \\
\hline & $(0.160)$ & $(0.236)$ & $(0.250)$ & $(0.242)$ & $(0.260)$ & $(0.156)$ \\
\hline \multirow[t]{2}{*}{ Water mills $1819 \times 1880$} & -0.194 & -0.039 & -0.038 & -0.034 & 0.029 & $0.440 * *$ \\
\hline & $(0.193)$ & $(0.248)$ & $(0.244)$ & $(0.227)$ & $(0.224)$ & $(0.169)$ \\
\hline \multirow{2}{*}{ Water mills $1819 \times 1885$} & $-0.343^{* *}$ & -0.188 & -0.189 & -0.169 & -0.116 & 0.065 \\
\hline & $(0.159)$ & $(0.198)$ & $(0.196)$ & $(0.205)$ & $(0.221)$ & $(0.260)$ \\
\hline \multirow{2}{*}{ Water mills $1819 \times 1890$} & $-0.511^{* *}$ & $-0.356^{* * *}$ & $-0.357^{* * *}$ & $-0.355^{* * *}$ & $-0.352^{* * *}$ & $-0.349^{* *}$ \\
\hline & $(0.199)$ & $(0.107)$ & $(0.105)$ & $(0.093)$ & $(0.082)$ & $(0.150)$ \\
\hline Period FE & Yes & Yes & Yes & Yes & Yes & Yes \\
\hline District FE & No & Yes & Yes & Yes & Yes & Yes \\
\hline Initial population $\times$ Period & No & No & Yes & Yes & Yes & Yes \\
\hline Lagged uprisings $\times$ Period & No & No & No & Yes & Yes & Yes \\
\hline East Elbe FE $\times$ Period & No & No & No & No & Yes & Yes \\
\hline Province FE $\times$ Period & No & No & No & No & No & Yes \\
\hline Observations & 190 & 190 & 190 & 190 & 190 & 190 \\
\hline$R^{2}$ & 0.53 & 0.60 & 0.70 & 0.73 & 0.73 & 0.92 \\
\hline Joint sig. $p$-value for mills & 0.000 & 0.000 & 0.000 & 0.000 & 0.000 & 0.000 \\
\hline Joint sig. $p$-value for population & & & 0.000 & 0.005 & 0.080 & 0.000 \\
\hline Joint sig. $p$-value for uprisings & & & & 0.002 & 0.015 & 0.000 \\
\hline Joint sig. $p$-value for East Elbe & & & & & 0.084 & 0.000 \\
\hline Joint sig. $p$-value for provinces & & & & & & 0.000 \\
\hline
\end{tabular}

Notes. The dependent variable is the log of the average annual number of emancipation cases settled in a district (under the 1821 ordinance) over a given 5-year period. The main explanatory variable is the number of water mills per 1,000 inhabitants in a district in 1819, and its distribution is standardized to possess a zero mean and unit standard deviation. By interacting the latter variable with time, it is allowed to possess a time-varying cross-district relationship with the dependent variable across 5-year periods, with the exception of the last period, which is treated as the omitted category. Initial population and the lagged number of social uprisings are both time-varying measures themselves, and they are each allowed to possess a time-varying cross-district relationship with the dependent variable across all 5-year periods. See Appendix A for additional details on all variables. The reported $p$-value for a given explanatory variable is from the $F$-test for joint significance of the coefficients associated with its interaction terms that capture its time-varying cross-district relationship with the dependent variable. Standard errors, clustered at the district level, are reported in parentheses. *** denotes statistical significance at the $1 \%$ level, $* *$ at the $5 \%$ level, and ${ }^{*}$ at the $10 \%$ level. 
cross-sectional findings, linking early industrialization with the subsequent pace of de facto labor emancipation at the county level, are likely not being driven by unobserved spatial heterogeneity in time-invariant geographical, cultural, or institutional characteristics.

In the remaining columns of Table 5, we examine the robustness of our baseline results to incrementally accounting for the time-varying influences of population size in the initial year (column 3) and the lagged number of social uprisings (column 4) on emancipation flow in a given 5year period, before additionally accounting for differential time trends in the emancipation process, first between regions to the west versus east of the river Elbe (column 5) and then across provinces in our sample (column 6). Importantly, the results from estimating these other specifications suggest that our baseline time-varying relationship of interest uncovered in column 2 remains virtually insensitive to the inclusion of additional controls in our model. Remarkably, it is only in the most stringent specification from column 6 that our baseline pattern becomes muted, particularly with respect to emancipation flows in the earlier periods of our sample horizon, but even then it remains not only qualitatively robust but also largely statistically significant.

In sum, corroborating our cross-sectional findings at the county level, the results from our district-level flexible panel analysis suggest that higher initial stakes of the elites in the ownership of physical capital are systematically associated with a more rapid subsequent decline in serfdom and, thus, faster convergence to state of full de facto labor emancipation.

\subsection{Emancipation and subsequent investments in human capital}

This section provides additional suggestive evidence corroborating our preferred interpretation of the positive reduced-form association between early industrialization and de facto serf emancipation across Prussian counties. Specifically, we empirically examine the extent to which ex post outcomes with respect to the accumulation of human capital by the masses are consistent with the ex ante incentives of capital-owning elites to support labor emancipation.

According to our conceptual framework, labor emancipation was facilitated by the elites who, due to their increasing stakes in the ownership of physical capital, rationally acted on their vested interests - rooted in capital-skill complementarity - to incentivize the acquisition of skills by the masses. Hence, one expects that emancipation should indeed have triggered or intensified subsequent society-wide human capital accumulation. ${ }^{50}$ In addition, if the incentives of the elites to emancipate labor were indeed associated with capital-skill complementarity, there should be a positive reduced-form link between initial capital-ownership by the elites and the intensity of skill acquisition by the masses after the emancipation process has been unraveling for several decades. Moreover, this link should be partially mediated by the intensity of emancipation itself, with the residual association between initial physical capital and post-emancipation human capital

\footnotetext{
${ }^{50}$ Cinnirella and Hornung (2016a) empirically document that the negative association between initial large landownership concentration and subsequent primary school enrollment rates across Prussian counties diminished over the course of the nineteenth century. The authors argue that this pattern can be explained by the stepwise de facto emancipation of labor and the nascent increase in the demand for human capital.
} 
TABLE 6: Cross-sectional analysis-Explaining educational investments

\begin{tabular}{|c|c|c|c|c|c|c|}
\hline \multirow[t]{3}{*}{ Dependent variable: } & \multicolumn{3}{|c|}{ Enrollment rate 1864} & \multicolumn{3}{|c|}{ Literacy rate 1871} \\
\hline & $(1)$ & $(2)$ & $(3)$ & $(4)$ & $(5)$ & $(6)$ \\
\hline & OLS & OLS & OLS & OLS & OLS & OLS \\
\hline \multirow[t]{2}{*}{ Serf emancipation 1821-48 } & $0.017^{* *}$ & & $0.013^{*}$ & $0.009^{* * *}$ & & $0.007 * *$ \\
\hline & $(0.007)$ & & $(0.007)$ & $(0.003)$ & & $(0.003)$ \\
\hline \multirow[t]{2}{*}{ Water mills 1819} & & $0.020^{* * *}$ & $0.017^{* * *}$ & & $0.009^{* * *}$ & $0.007^{* * *}$ \\
\hline & & $(0.005)$ & $(0.006)$ & & $(0.002)$ & $(0.002)$ \\
\hline \multirow[t]{2}{*}{ Enrollment rate 1816} & $0.233^{* * *}$ & $0.210^{* * *}$ & $0.207^{* * *}$ & $0.207^{* * *}$ & $0.197^{* * *}$ & $0.195^{* * *}$ \\
\hline & $(0.063)$ & $(0.059)$ & $(0.058)$ & $(0.029)$ & $(0.029)$ & $(0.029)$ \\
\hline Geographical controls & Yes & Yes & Yes & Yes & Yes & Yes \\
\hline Other proximate controls & Yes & Yes & Yes & Yes & Yes & Yes \\
\hline Observations & 261 & 261 & 261 & 261 & 261 & 261 \\
\hline Adjusted $R^{2}$ & 0.64 & 0.65 & 0.66 & 0.89 & 0.89 & 0.90 \\
\hline Partial $R^{2}$ of emancipation & 0.04 & & 0.02 & 0.03 & & 0.02 \\
\hline Partial $R^{2}$ of mills & & 0.07 & 0.05 & & 0.04 & 0.02 \\
\hline
\end{tabular}

Notes. In columns $1-3$, the dependent variable is total attendance across primary schools in a county in 1864 , expressed as a fraction of the county's population of children of recommended schooling age (6 to 14) in the same year. In columns 4-6, the dependent variable is the literacy rate amongst the population aged 10 and above in a county in 1871. The preceding intensity of serf emancipation is measured as the total number of emancipation cases settled in a county (under the 1821 ordinance) as of 1848, expressed as a fraction of the rural population of the county in 1816 (net of the population in small peasant landholdings). The initial ownership of physical capital by the elites is measured as the number of water mills per 1,000 inhabitants in a county in 1819. Both of these explanatory variables are standardized to possess zero means and unit standard deviations. See Appendix A and the discussion in Section 4 for additional details on all variables. Standard errors, clustered at the district level, are reported in parentheses. ${ }^{* *}$ denotes statistical significance at the $1 \%$ level, $* *$ at the $5 \%$ level, and $*$ at the $10 \%$ level.

accumulation partly reflecting the normal demand for human capital associated with capital-skill complementarity.

Table 6 presents the results from an analysis that vindicates the aforementioned priors by linking our measures of early industrialization and the intensity of serf emancipation between 1821 and 1848 with two alternative indicators of the intensity of human capital accumulation following several decades of the onset of emancipation: the primary school enrollment rate in 1864 (columns 1-3) and the literacy rate amongst the population aged 10 and above in 1871 (columns 46). Throughout the analysis, our regressions account for our baseline set of geographical covariates from Table 1 as well as the full set of additional control variables considered in Table 2. Importantly, the latter set of covariates includes the primary school enrollment rate in 1816, which accounts for the potentially confounding influence of the initial intensity of investments in human capital in the context of the current analysis. Namely, early human capital accumulation could have not only driven both initial physical capital accumulation and subsequent labor emancipation but may also be positively associated with the intensity of post-emancipation skill acquisition through other mechanisms of structural persistence. 
The results presented in columns 1 and 4 indicate that in line with priors, conditional on heterogeneity across counties in geographical factors and more proximate confounders, the share of serfs emancipated between 1821 and 1848 is positively and statistically significantly associated with either measure of the intensity of investments in human capital in the second half of the nineteenth century. Further, columns 2 and 5 suggest that consistently with the emergence of capital-skill complementarity and the associated rise in the demand for human capital over the course of industrialization, the prevalence of water mills in 1819 also bears a positive and statistically significant reduced-form relationship with either indicator of the intensity of skill acquisition in the latter half of the nineteenth century.

Finally, as one might expect from a setting where emancipation is triggered by capitalowning elites as a vehicle to incentivize investments in basic skills by the masses, the results in columns 3 and 6 show that in a "horse race" between the share of serfs emancipated by 1848 and our proxy for the extent of early industrialization, both variables possess significant positive associations with either outcome measure of human capital accumulation, but the reduced-form influence of the initial prevalence of water mills becomes somewhat diminished in comparison to the relevant point estimates from columns 2 and 5. In addition, the finding that the initial prevalence of water mills continues to enter the regressions with a significant positive coefficient presumably reflects the demand for skilled workers arising from the capital-skill complementarity that remains salient even in the absence of coercive labor institutions that curb the incentives to acquire skills.

We conclude this section by emphasizing the mostly suggestive nature of the corroborating evidence uncovered here. Specifically, although our findings in this section are indeed broadly consistent with our conceptual framework of the historical decline in serfdom, we remain cautious with interpreting them as conclusive per se, primarily due to the possibility that our vector of covariates, despite being sizable, may not be sufficient to fully surmount the potential endogeneity of our measures of early industrialization and emancipation intensity with the subsequent pace of human capital accumulation.

\section{Concluding remarks}

In this paper, we advance and empirically explore the novel hypothesis that the historical decline in institutions of labor coercion, particularly, the de facto emancipation of labor from serfdom, occurred partly as a natural by-product of the process of industrialization, reflecting changes over time in the economic incentives of landowning capitalist elites. Specifically, due to capital-skill complementarity, the accumulation of physical capital by the elites in early stages of industrialization eventually raised their demand for skilled workers from society at large. Because skill acquisition by the masses requires private effort that is costly to monitor, the elites eventually found it incentivecompatible to end the extant regime of labor coercion, in order to encourage the masses to invest in human capital under the credible commitment that their skill premium would not face further risk of expropriation. Our hypothesis therefore suggests that, all else equal, the economic incentives 
of the elites to ultimately support labor emancipation would have been mobilized faster the larger were their stakes in the ownership of physical capital in early stages of industrialization.

Exploiting a unique data set on cases of de facto serf emancipation in nineteenth-century Prussia, we document empirical patterns that are consistent with our hypothesis. Our findings indicate a positive and significant relationship across Prussian counties between the initial stock of physical capital per capita, as proxied by the prevalence of water mills in the early nineteenth century, and the share of serfs that were de facto emancipated by the mid-nineteenth century. We document the robustness of this cross-sectional relationship to accounting for a wide range of potentially confounding factors, including observed heterogeneity across regions in geographical, cultural, and institutional characteristics and in various dimensions of historical development. We further show that the relationship remains both qualitatively and quantitatively insensitive to exploiting terrain slope as a plausibly exogenous source of spatial variation in our proxy for the initial stock of physical capital.

Complementing our cross-sectional analysis at the Prussian county level, we also exploit differential temporal variation in the flow of de facto serf emancipation cases across Prussian districts over the latter half of the nineteenth century, finding that a higher initial stock of physical capital is associated with a more rapid convergence to full emancipation during this time horizon. By controlling for district fixed effects, our flexible panel setting allows us to address concerns regarding endogeneity that might arise from unobserved heterogeneity in time-invariant characteristics at the district level. This setting also permits us to account for the potentially confounding time-varying effects of labor abundance and social uprisings at the district level, as well as region-specific time trends in emancipation flows at higher levels of spatial aggregation.

Finally, we provide two pieces of corroborating evidence that support our preferred interpretation of the positive reduced-form cross-sectional relationship at the county level between the initial stock of physical capital and the prevalence of de facto serf emancipation by the midnineteenth century. Specifically, we show that a larger initial stock of physical capital is associated with a lower average cost of redemption per emancipation case as of the mid-nineteenth century, indicating that in counties where the elites had higher stakes in the ownership of physical capital, they were also willing to settle for lower compensation payments in exchange for the redemption of lifetime servile duties by their serfs. Furthermore, in line with the realization of indirect outcomes that are consistent with the ex ante incentives of the elites to grant freedom to their serfs, we find that conditional on the initial stock of physical capital, counties in which de facto emancipation had occurred more intensely by the mid-nineteenth century also exhibit a higher rate of subsequent human capital accumulation by the masses, as reflected by higher enrollment rates in primary schools and higher literacy rates during the latter half of the nineteenth century. 


\section{References}

Acemoglu, Daron and Alexander Wolitzky, "The Economics of Labor Coercion," Econometrica, March 2011, 79 (2), 555-600.

_ and James A. Robinson, "Why Did the West Extend the Franchise? Democracy, Inequality, and Growth in Historical Perspective," Quarterly Journal of Economics, November 2000, 115 (4), 1167-1199.

_ and _, Why Nations Fail: The Origins of Power, Prosperity, and Poverty, New York: Crown Publishers, 2012.

_, Davide Cantoni, Simon Johnson, and James A. Robinson, "The Consequences of Radical Reform: The French Revolution," American Economic Review, December 2011, 101 (7), $3286-3307$.

Aidt, Toke S. and Raphaël Franck, "Democratization Under the Threat of Revolution: Evidence From the Great Reform Act of 1832," Econometrica, March 2015, 83 (2), 505-547.

Altonji, Joseph G., Todd E. Elder, and Christopher R. Taber, "Selection on Observed and Unobserved Variables: Assessing the Effectiveness of Catholic Schools," Journal of Political Economy, February 2005, 113 (1), 151-184.

Barro, Robert J., "Determinants of Democracy," Journal of Political Economy, December 1999, 107 (S6), S158-S183.

_ , "Convergence and Modernisation," Economic Journal, June 2015, 125 (585), 911-942.

Becker, Sascha O. and Ludger Woessmann, "Was Weber Wrong? A Human Capital Theory of Protestant Economic History," Quarterly Journal of Economics, May 2009, 124 (2), 531-596.

_, Erik Hornung, and Ludger Woessmann, "Education and Catch-Up in the Industrial Revolution," American Economic Journal: Macroeconomics, July 2011, 3 (3), 92-126.

_, Francesco Cinnirella, and Ludger Woessmann, "The Trade-off between Fertility and Education: Evidence from before the Demographic Transition," Journal of Economic Growth, September 2010, 15 (3), 177-204.

_ , , and _ , "The Effect of Investment in Children's Education on Fertility in 1816 Prussia," Cliometrica, January 2012, 6 (1), 29-44.

Berdahl, Robert M., The Politics of the Prussian Nobility: The Development of a Conservative Ideology, 1770-1848, Princeton: Princeton University Press, 1988.

Berthold, Rudolf, "Die Veränderungen im Bodeneigentum und in der Zahl der Bauernstellen, der Kleinstellen und der Rittergüter in den preußischen Provinzen Sachsen, Brandenburg und 
Pommern während der Durchführung der Agrarreformen des 19. Jahrhunderts," Jahrbuch für Wirtschaftsgeschichte / Economic History Yearbook, December 1978, 19 (Supplement), 7-116.

Bertocchi, Graziella and Arcangelo Dimico, "Slavery, Education, and Inequality," European Economic Review, August 2014, 70, 197-209.

Biernacki, Richard, The Fabrication of Labor: Germany and Britain, 1640-1914, Berkeley: The University of California Press, 1995.

Bloch, Marc, Land and Work in Medieval Europe: Selected Papers, Berkeley: The University of California Press, 1967. Translated by J. E. Anderson.

Bobonis, Gustavo J. and Peter M. Morrow, "Labor Coercion and the Accumulation of Human Capital," Journal of Development Economics, May 2014, 108, 32-53.

Böhme, Karl, Gutsherrlich-bäuerliche Verhältnisse in Ostpreussen während der Reformzeit von 1770 bis 1830: Gefertigt nach den Akten der Gutsarchiv zu Angerapp und Gr.-Steinort, Leipzig: Duncker \& Humbolt, 1902.

Bowman, Shearer Davis, "Antebellum Planters and Vormärz Junkers in Comparative Perspective," American Historical Review, October 1980, 85 (4), 779-808.

_, Masters and Lords: Mid-19th-Century U.S. Planters and Prussian Junkers, New York: Oxford University Press, 2011.

Brenner, Robert, "Agrarian Class Structure and Economic Development in Pre-Industrial Europe," Past and Present, February 1976, 70, 30-75.

Buggle, Johannes C., "Law and Social Capital: Evidence from the Code Napoleon in Germany," European Economic Review, August 2016, 87, 148-175.

- and Steven Nafziger, "Long-Run Consequences of Labor Coercion: Evidence from Russian Serfdom," 2015. http://www.johannesbuggle.com/docs/serfdom_1.4.pdf.

Carsten, Francis L., Geschichte der preußischen Junker, Frankfurt: Suhrkamp, 1988.

Cinnirella, Francesco and Erik Hornung, "Landownership Concentration and the Expansion of Education," Journal of Development Economics, July 2016a, 121, 135-152.

_ and _ , "Land Inequality, Education, and Marriage: Empirical Evidence from NineteenthCentury Prussia," 2016b. CESifo Working Paper No. 6072, Center for Economic Studies \& Ifo Institute.

- and Jochen Streb, "The Role of Human Capital and Innovation in Economic Development: Evidence from Post-Malthusian Prussia," forthcoming. Journal of Economic Growth. 
Dippel, Christian, Avner Greif, and Daniel Trefler, "The Rents from Trade and Coercive Institutions: Removing the Sugar Coating," 2015. NBER Working Paper No. 20958, National Bureau of Economic Research.

Dipper, Christof, Die Bauernbefreiung in Deutschland, 1790-1850, Stuttgart: Kohlhammer, 1980.

Domar, Evsey D., "The Causes of Slavery or Serfdom: A Hypothesis," Journal of Economic History, March 1970, 30 (1), 18-32.

Eddie, Scott M., Landownership in Eastern Germany before the Great War: A Quantitative Analysis, New York: Oxford University Press, 2008.

Eddie, Sean A., Freedom's Price: Serfdom, Subjection, and Reform in Prussia, 1648-1848, New York: Oxford University Press, 2013.

EROS, U.S. Geological Survey, "GTOPO30," 1996. Center for Earth Resources Observation and Science, United States Geological Survey, Sioux Falls, SD. https://lta.cr.usgs.gov/GTOPO30 (accessed July 27, 2015).

Fenoaltea, Stefano, "Slavery and Supervision in Comparative Perspective: A Model," Journal of Economic History, September 1984, 44 (3), 635-668.

Fenske, James, "Does Land Abundance Explain African Institutions?," Economic Journal, December 2013, 123 (573), 1363-1390.

Fernihough, Alan and Kevin Hjortshøj O'Rourke, "Coal and the European Industrial Revolution," 2014. NBER Working Paper No. 19802, National Bureau of Economic Research.

Franck, Raphaël and Oded Galor, "Technology-Skill Complementarity in Early Phases of Industrialization," 2017. NBER Working Paper No. 23197, National Bureau of Economic Research.

Galor, Oded, Unified Growth Theory, Princeton: Princeton University Press, 2011.

- and Joseph Zeira, "Income Distribution and Macroeconomics," Review of Economic Studies, January 1993, 60 (1), 35-52.

- and Omer Moav, "From Physical to Human Capital Accumulation: Inequality and the Process of Development," Review of Economic Studies, October 2004, 71 (4), 1001-1026.

_ and _ "Das Human-Kapital: A Theory of the Demise of the Class Structure," Review of Economic Studies, January 2006, 73 (1), 85-117.

_ , _ , and Dietrich Vollrath, "Inequality in Landownership, the Emergence of Human-Capital Promoting Institutions, and the Great Divergence," Review of Economic Studies, January 2009, $76(1), 143-179$. 
Glaeser, Edward L., Giacomo A. M. Ponzetto, and Andrei Shleifer, "Why Does Democracy Need Education?," Journal of Economic Growth, June 2007, 12 (2), 77-99.

_, Rafael La Porta, Florencio Lopez de Silanes, and Andrei Shleifer, "Do Institutions Cause Growth?," Journal of Economic Growth, September 2004, 9 (3), 271-303.

Görlitz, Walter, Die Junker - Adel und Bauer im deutschen Osten, 4th ed., Limburg an der Lahn: Starke, 1981.

Grant, Oliver, Migration and Inequality in Germany 1870-1913. Oxford Historical Monographs, New York: Oxford University Press, 2005.

Gutberlet, Theresa, "Mechanization and the Spatial Distribution of Industries in the German Empire, 1875 to 1907," Economic History Review, May 2014, 67 (2), 463-491.

Habakkuk, H. John, "Family Structure and Economic Change in Nineteenth-Century Europe," Journal of Economic History, March 1955, 15 (1), 1-12.

Hagen, William W., Ordinary Prussians: Brandenburg Junkers and Villagers, 1500-1840, Cambridge: Cambridge University Press, 2002.

Harnisch, Hartmut, "Statistische Untersuchungen zum Verlauf der kapitalistischen Agrarreformen in den preussischen Ostprovinzen (1811 bis 1865)," Jahrbuch für Wirtschaftsgeschichte / Economic History Yearbook, April 1974, 15 (4), 149-182.

_, Kapitalistische Agrarreform und Industrielle Revolution, Weimar: Böhlau, 1984.

_, "Peasants and Markets: The Background to the Agrarian Reforms in Feudal Prussia East of the Elbe, 1760-1807," in Richard J. Evans and W. R. Lee, eds., The German Peasantry: Conflict and Community in Rural Society from the Eighteenth to the Twentieth Centuries, London: Croom Helm, 1986, pp. 37-70.

Hijmans, Robert J., Susan E. Cameron, Juan L. Parra, Peter G. Jones, and Andy Jarvis, "Very High Resolution Interpolated Climate Surfaces for Global Land Areas," International Journal of Climatology, December 2005, 25 (15), 1965-1978.

Hills, Richard L., Power from Wind: A History of Windmill Technology, Cambridge: Cambridge University Press, 1996.

Hornung, Erik, "Railroads and Growth in Prussia," Journal of the European Economic Association, August 2015, 13 (4), 699-736.

IEG, "IEG-Maps: Server for Digital Historical Maps," 2010. Leibniz Institute of European History, Mainz, Germany. http://www.ieg-maps.uni-mainz.de/ (first accessed November 2010).

Kiesewetter, Hubert, Industrielle Revolution in Deutschland: Regionen als Wachstumsmotoren, Stuttgart: Franz Steiner, 2004. 
Knapp, Georg Friedrich, Die Bauern-Befreiung und der Ursprung der Landarbeiter in den älteren Theilen Preußens, Leipzig: Duncker \& Humblot, 1887.

Königlichen Statistischen Bureau, Preussische Statistik, Vol. 1-305, Berlin: Königliches Statistisches Bureau, 1861-1934.

_ , Die Gemeinden und Gutsbezirke des Preussischen Staates und ihre Bevölkerung: Nach den Urmaterialien der allgemeinen Volkszählung vom 1. December 1871, Vol. 1-11, Berlin: Königliches Statistisches Bureau, 1874.

Lagerlöf, Nils-Petter, "Slavery and Other Property Rights," Review of Economic Studies, January 2009, 76 (1), 319-342.

_ , "Born Free," Journal of Development Economics, July 2016, 121, 1-10.

Lipset, Seymour Martin, "Some Social Requisites of Democracy: Economic Development and Political Legitimacy," American Political Science Review, March 1959, 53 (1), 69-105.

Lucas, Adam, Wind, Water, Work: Ancient and Medieval Milling Technology, Leiden: Brill, 2006.

Markevich, Andrei and Ekaterina Zhuravskaya, "Economic Effects of the Abolition of Serfdom: Evidence from the Russian Empire," 2015. CEPR Discussion Paper No. 10398, Centre for Economic Policy Research.

McElroy, Brendan, "Labor Coercion and Human Capital-Promoting Institutions: Evidence from Russia," 2015. http://scholar.harvard.edu/files/bmcelroy/files/mcelroy_serfdom_12.2015.pdf.

Meitzen, August, Der Boden und die landwirthschaftlichen Verhältnisse des Preussischen Staates, Vol. 1-4, Berlin: Wiegandt \& Hempel, 1868.

Melton, Edgar, "The Transformation of the Rural Economy in East Elbian Prussia, 1750-1830," in Philip G. Dwyer, ed., The Rise of Prussia 1700-1830, New York: Longman, 2000, pp. 111-128.

Melton, James Van Horn, Absolutism and the Eighteenth-Century Origins of Compulsory Schooling in Prussia and Austria, Cambridge: Cambridge University Press, 1988.

Millward, Robert, "The Early Stages of European Industrialization: Economic Organization under Serfdom," Explorations in Economic History, October 1984, 21 (4), 406-428.

Mokyr, Joel, The Gifts of Athena: Historical Origins of the Knowledge Economy, Princeton: Princeton University Press, 2002.

Mützell, Alexander August, Neues Topographisch-Statistisch-Geographisches Wörterbuch des Preussischen Staats, Vol. 5-6, Halle: Karl August Kümmel, 1823-1825. 
Nafziger, Steven, "Serfdom, Emancipation, and Off-farm Labour Mobility in Tsarist Russia," Economic History of Developing Regions, 2012, 27 (1), 1-37.

Naidu, Suresh and Noam Yuchtman, "Coercive Contract Enforcement: Law and the Labor Market in Nineteenth Century Industrial Britain," American Economic Review, February 2013, 103 (1), 107-144.

North, Douglass C. and Robert Paul Thomas, The Rise of the Western World: A New Economic History, Cambridge: Cambridge University Press, 1973.

Ogilvie, Sheilagh, "Serfdom and the Institutional System in Early Modern Germany," in Simonetta Cavaciocchi, ed., Serfdom and Slavery in the European Economy, 11th-18th Centuries, Florence: Firenze University Press, 2014, pp. 33-58.

- and A. W. Carus, "Institutions and Economic Growth in Historical Perspective," in Philippe Aghion and Steven N. Durlauf, eds., Handbook of Economic Growth, Vol. 2A, Amsterdam: Elsevier B.V., 2014, pp. 403-513.

Pierenkemper, Toni, Die westfälischen Schwerindustriellen 1852-1913: Soziale Struktur und unternehmerischer Erfolg Kritische Studien zur Geschichtswissenschaft, Bd. 36, Göttingen: Vandenhoeck \& Ruprecht, 1978.

_, Landwirtschaft und industrielle Entwicklung: Zur ökonomischen Bedeutung von Bauernbefreiung, Agrarreform und Agrarrevolution, Stuttgart: Franz Steiner, 1989.

- and Richard Tilly, The German Economy during the Nineteenth Century, New York: Berghahn, 2004.

Postan, M. M., "Medieval Agrarian Society in its Prime: England," in M. M. Postan, ed., The Cambridge Economic History of Europe from the Decline of the Roman Empire, Vol. 1: The Agrarian Life of the Middle Ages, Cambridge: Cambridge University Press, 1966, pp. 548-632.

Rauer, Karl Friedrich, Hand-Matrikel der in sämmtlichen Kreisen des Preussischen Staats auf Kreis- und Landtagen vertretenen Rittergüter, Berlin: Selbstverlag, 1857.

Reddy, William M., Money and Liberty in Modern Europe: A Critique of Historical Understanding, Cambridge: Cambridge University Press, 1987.

Rosenberg, Hans, Machteliten und Wirtschaftskonjunkturen: Studien zur neueren deutschen Sozial- und Wirtschaftsgeschichte Kritische Studien zur Geschichtswissenschaft, Bd. 31, Göttingen: Vandenhoeck \& Ruprecht, 1978.

Rudolph, Richard L., "Major Issues in the Study of the European Peasant Family, Economy, and Society," in Richard L. Rudolph, ed., The European Peasant Family and Society: Historical Studies, Liverpool: Liverpool University Press, 1995, pp. 6-25. 
Sacerdote, Bruce, "Slavery and the Intergenerational Transmission of Human Capital," Review of Economics and Statistics, May 2005, 87 (2), 217-234.

Schiller, René, Vom Rittergut zum Grossgrundbesitz: Ökonomische und soziale Transformationsprozesse der ländlichen Eliten in Brandenburg im 19. Jahrhundert Elitenwandel in der Moderne, Berlin: Walter de Gruyter, 2003.

Schissler, Hanna, Preußische Agrargesellschaft im Wandel: wirtschaftliche, gesellschaftliche und politische Transformationsprozesse von 1763 bis 1847 Kritische Studien zur Geschichtswissenschaft, Bd. 33, Göttingen: Vandenhoeck \& Ruprecht, 1978.

Sering, Max, Die Vererbung des ländlichen Grundbesitzes im Königreich Preussen, Vol. 1-14, Berlin: Paul Parey, 1897-1905.

Skocpol, Theda, States and Social Revolutions: A Comparative Analysis of France, Russia, and China, Cambridge: Cambridge University Press, 1979.

Squicciarini, Mara P. and Nico Voigtländer, "Human Capital and Industrialization: Evidence from the Age of Enlightenment," Quarterly Journal of Economics, November 2015, 130 (4), 18251883.

Statistisches Bureau zu Berlin, Tabellen und amtliche Nachrichten über den Preussischen Staat für das Jahr 1849, Vol. 1-6b, Berlin: A. W. Hayn, 1851-1855.

Tilly, Richard H., "Capital Formation in Germany in the Nineteenth Century," in Peter Mathias and M. M. Postan, eds., The Cambridge Economic History of Europe, Vol. 7: The Industrial Economies: Capital, Labour and Enterprise, Part 1: Britain, France, Germany and Scandinavia, Cambridge: Cambridge University Press, 1978, pp. 382-441.

_ , "Social Protest in Germany in the 19th Century," 1990. ZA8040 Data file Version 1.0.0, GESIS Data Archive, Cologne, Germany. doi:10.4232/1.8040.

van der Beek, Karine, "The Effects of Political Fragmentation on Investments: A Case Study of Watermill Construction in Medieval Ponthieu, France," Explorations in Economic History, October 2010, 47 (4), 369-380.

von Nathusius, Elsbeth Luise Friederike, Johann Gottlob Nathusius: ein Pionier deutscher Industrie, Stuttgart and Berlin: Deutsche Verlags-Anstalt, 1915.

Wehler, Hans-Ulrich, Deutsche Gesellschaftsgeschichte, Bd. 1: Vom Feudalismus des Alten Reiches bis zur defensiven Modernisierung der Reformära 1700-1815, 4th ed., München: C. H. Beck, 2006. 


\section{Appendix A Variable definitions and data sources}

\section{A.1 Variables in the cross-sectional analysis}

Serf emancipation 1821-48. The cumulative stock of emancipation cases settled in a county between 1821 and 1848, expressed as a fraction of the county's rural population (net of those ineligible for emancipation until after 1850) in 1816. The numerator of this variable reflects county-level data reported by Meitzen (1868, vol. 4), capturing only those settled emancipation cases in which former service and duty payers (Dienst- und Agabenpflichtige, welche abgelöst haben) redeemed their lifetime servile duties under the Dissolution Ordinance of 1821 (Ablösungsordnung). ${ }^{51}$ For the denominator of this variable, the data on a county's rural population in 1816 is sourced from Mützell (1823-1825, vol. 6), but this information is then adjusted to exclude the subpopulation, reported at the county level by Meitzen (1868, vol. 4), of the peasant landowners residing on small parcels (with weak land tenure rights) that were ineligible for redeeming their lifetime servile dues under the 1821 ordinance (nichtspannfähige bäuerliche Nahrungen) and were only able to do so after the passage of the Commutation Law in 1850. This variable is standardized to possess a mean of zero and a standard deviation of one in each of the regression samples considered by our cross-sectional analysis.

Water mills 1819. The number of water mills used for the grinding of grains into flour, grits, or pearl barley in a county in 1819, divided by the county's population (in thousands) in 1821 (the population census year closest to 1819), constructed using county-level data reported by Mützell (1823-1825, vol. 6). This variable is standardized to possess a mean of zero and a standard deviation of one in each of the regression samples considered by our cross-sectional analysis.

Terrain slope. The average slope of the terrain in a county, constructed using geospatial elevation information reported in Data Basin's "30 arc-second DEM of Europe" data set (https: //databasin.org/datasets/7a286ca8a7fa492a9f95d58324ca918c), which is, in turn, derived from the U.S. Geological Survey's GTOPO30 data set (EROS, 1996). GTOPO30 is a global digital elevation model (DEM) that provides elevation information at a resolution of 30 arc seconds (i.e., grid cells of approximately 1 kilometer squared each). The measurement of this variable proceeds by first calculating for each grid cell the maximum of the elevation difference in degrees between itself and each of its eight neighboring cells and then averaging this information across all grid cells in a county.

Average temperature. The average temperature in degrees Celsius in a county during the 1960-1990 time horizon, constructed by temporally and spatially aggregating time series information on mean monthly temperature at a geospatial resolution of 30 arc seconds (i.e., grid cells

\footnotetext{
${ }^{51}$ The number of settled emancipation cases is missing for five counties in the districts of Königsberg and Gumbinnen. For four of these counties, we imputed the the number of settled cases based on information pertaining to redeemed labor services and redemption costs. No such information was available for one county (Lyk), which remains missing from our sample. Furthermore, in two instances, the 1848 emancipation census reports the number of settled cases and redemption costs for two counties combined. In these cases, we decided to assign the same value for the share of emancipated serfs to each of the two counties.
} 
of approximately 1 kilometer squared each), obtained from the WorldClim (version 1) data set (http://www.worldclim.org/version1) of Hijmans et al. (2005).

Average precipitation. The average precipitation in hundreds of millimeters in a county during the 1960-1990 time horizon, constructed by temporally and spatially aggregating time series information on total monthly precipitation at a geospatial resolution of 30 arc seconds (i.e., grid cells of approximately 1 kilometer squared each), obtained from the WorldClim (version 1) data set (http://www.worldclim.org/version1) of Hijmans et al. (2005).

Distance to navigable river. The distance in hundreds of kilometers from a county's centroid to the nearest navigable river, constructed using a map of all waterways (Schiffahrtsstraßen) in the Zollverein (German Customs Union) in 1850 (http://www.ieg-maps.uni-mainz.de/mapsp/ mapw850d.htm), hosted by the "Server for Digital Historical Maps" at the Leibniz Institute of European History at the University of Mainz (IEG, 2010).

Soil suitability (cereals). The average suitability of the soil in a county for growing cereal crops, constructed by spatially aggregating information on an agro-ecological suitability index (class) for low-input-level rain-fed cereal crops at a geospatial resolution of 30 arc seconds (i.e., grid cells of approximately 1 kilometer squared each), obtained from the Food and Agriculture Organization's (FAO) Global Agro-Ecological Zones (GAEZ) Data Portal version 3.0 (http://gaez.fao.org).

Sandy soil (share). The share of a county's land area in which the soil texture is classified as sandy (i.e., where the soil is composed of $85-100 \%$ sand, $0-15 \%$ silt, and $0-15 \%$ clay), constructed using county-level data reported by Meitzen (1868, vol. 4). ${ }^{52}$ The underlying data for this variable was collected by an 1866 census, which assessed the composition of the soil in a county by gathering information on three main soil categories: the area of "clay soils" (Lehm- und Thonböden), the area of "sandy loam and loamy sand soils" (sandiger Lehm und lehmiger Sand), and the area of "sandy soils" (Sandboden).

East Elbe (dummy). A binary variable that assumes a value of one for counties located on or east of the river Elbe, and zero otherwise.

Population density 1816. The population of a county in 1816, divided by the county's land area (measured in Prussian Morgen), constructed using county-level data reported by Mützell (18231825, vol. 6).

Urbanization rate 1816. The total number of inhabitants across cities that held city rights in a county in 1816, divided by the county's population in 1816, constructed using city- and county-level data reported by Mützell (1823-1825, vol. 5-6).

\footnotetext{
${ }^{52}$ To elaborate on what this measure captures, it may be noted that the ideal soil texture for agricultural productivity has a composition of roughly $40 \%$ sand, $40 \%$ silt, and $20 \%$ clay. The suitability of a particular texture of the soil for agriculture is determined by the physical properties of soil particles; sand particles are relatively round, whereas silt and clay particles are relatively slim. Although the presence of round particles in the soil permits the absorption and retention of higher amounts of air and water, this is only true up to a certain point for water retention; soils excessively rich in sand are unable to retain water due to the presence of a large amount of empty spaces between particles, thus leading to a higher likelihood of drought and crop failure.
} 
Family size 1849. The population of a county in 1849 , divided by the number of families in the county in 1849, constructed using county-level data reported by the Statistisches Bureau zu Berlin (1851-1855, vol. 1).

Knight estates (share). The number of knight estates (Rittergüter) in a county in 1856 as reported by Rauer (1857), divided by the number of all landholdings in the county in 1849 as reported by the Statistisches Bureau zu Berlin (1851-1855, vol. 5). ${ }^{53}$ This variable is expressed in percentage points.

Protestants 1816 (share). The number of a county's inhabitants that belonged to the Reformed or Lutheran Protestant religious denomination in 1816, divided by the county's population in 1816, constructed using county-level data reported by Mützell (1823-1825, vol. 6).

Other ethnic group 1861 (share). The number of a county's inhabitants that were not of ethnic German descent (Stammesverschiedenheit) in 1861, divided by the county's population in 1861, constructed using county-level data reported by the Königlichen Statistischen Bureau (18611934, vol. 10).

Partible inheritance law (dummy). A binary variable that assumes a value of one for counties that predominantly practiced partible inheritance (Realteilung), and zero for counties that predominantly practiced primogeniture (Anerbenrecht), coded using county-level maps from circa-1900 on historical inheritance laws (Sering, 1897-1905).

Enrollment rate 1816. The total number of enrolled students across a county's public elementary schools (Öffentliche Elementarschulen), private elementary schools (Privat-Elementarschulen), public middle schools for boys or girls (Öffentliche Bürger- und Mittelschulen für Söhne oder Töchter), and private middle schools for boys or girls (Private Bürger- und Mittelschulen für Söhne oder Töchter) in 1816, divided by the county's population of children of recommended schooling age (6 to 14) in 1816, constructed using town- and county-level data reported by Mützell (1823-1825, vol. $5-6) .{ }^{54}$

Servile duties (PCA). The first principal component of the average amounts (per settlement) associated with two different types of labor services redeemed in the emancipation cases settled in a county as of 1848 . This variable is constructed using county-level data reported by Meitzen (1868, vol. 4). The settled emancipation cases considered are those in which former service and duty payers (Dienst- und Agabenpflichtige, welche abgelöst haben) redeemed their lifetime servile duties under the Dissolution Ordinance of 1821 (Ablösungsordnung). The two types of labor services included in the principal component analysis are "draft animal services" (Spanndienste) and "hand labor

\footnotetext{
${ }^{53}$ Although 1856 is the earliest available census on the number of knight estates in a county, Rauer (1857) provides additional information asserting that the spatial distribution of knight estates across Prussia remained largely stable throughout the first half of the nineteenth century. For instance, only 324 out of 11,714 knight estates lost their noble prerogatives during the 1834-1856 time period.

${ }^{54}$ Of the four types of schools, public elementary schools were the only ones prevalent in both rural and urban areas in 1816. Our data source provides information on student enrollment in public elementary schools at the county level in 1816, and we supplement this with aggregated town-level information on enrollment in private and middle schools across all medium and large towns in a county.
} 
services" (Handdienste), both measured in days. This variable, which captures $93 \%$ of the combined variation across counties in the two underlying measures of labor services, is standardized to possess a mean of zero and a standard deviation of one in each of the regression samples considered by our cross-sectional analysis.

Road 1848 (dummy). A binary variable that assumes a value of one for counties connected to at least one main road in 1848, and zero otherwise. The coding of this variable is based on a map of all paved and unpaved main roads (Hauptstraßen) in the Zollverein (German Customs Union) in 1848 (http://www.ieg-maps.de/mapsp/maproads1848.htm), hosted by the "Server for Digital Historical Maps" at the Leibniz Institute of European History at the University of Mainz (IEG, 2010).

Railway 1848 (dummy). A binary variable that assumes a value of one for counties connected to at least one railway line in 1848, and zero otherwise. The coding of this variable is based on a map of all railway lines (Eisenbahnen) in the Zollverein (German Customs Union) in 1848 (http: //www.ieg-maps.de/mapsp/mape848d.htm), hosted by the "Server for Digital Historical Maps" at the Leibniz Institute of European History at the University of Mainz (IEG, 2010).

Coalfield (dummy). A binary variable that assumes a value of one for counties that had access to a coalfield (i.e., those in which a coalfield was located within 10 kilometers of the county's geodesic centroid), and zero otherwise, coded using geospatial data on the location of coalfields from Fernihough and O'Rourke (2014).

Number of uprisings 1816-47. The number of violent protests, each involving at least 20 participants, in a county during the 1816-1847 time period, constructed using data reported by Tilly (1990) on the location and timing of such protests.

Crown and state domains (share). The total land area across a county's real estates that either belonged to the Crown and members of the royal family or belonged to the state in 1861, including domains and forests (Eigenthum des Staats: Domainen und Forsten), divided by the total land area across all real estates (Ertragfähige Liegenschaften) in the county in 1861, constructed using county-level data reported by Meitzen (1868, vol. 4).

Kulm estates (share). The number of a county's noble estates that were constituted under the Kulm law (Kölmische Güter) or whose legal constitution was consistent with the Kulm law (den kölmischen gleichartige) in 1856, divided by the number of all noble estates in the county in 1856 , constructed using county-level data reported by Rauer (1857).

Born outside county 1871 (share). The number of a county's inhabitants in 1871 that were born outside the county, divided by the county's population in 1871, constructed using county-level data reported by the Königlichen Statistischen Bureau (1861-1934, vol. 30).

Redemption costs (PCA). The first principal component of the average amounts (per settlement) associated with four different types of compensation payments made by peasants to redeem their lifetime labor services in the emancipation cases settled in a county as of 1848 . This variable 
is constructed using county-level data reported by Meitzen (1868, vol. 4). The settled emancipation cases considered are those in which former service and duty payers (Dienst- und Agabenpflichtige, welche abgelöst haben) redeemed their lifetime servile duties under the Dissolution Ordinance of 1821 (Ablösungsordnung). The four types of compensation payments included in the principal component analysis are "capital" (Kapital), measured in Prussian Thaler; "cash annuities" (Geldrente), measured in Prussian Thaler; "rye annuities" (Roggenrente), measured in Prussian Scheffel; and "land" (Land), measured in Prussian Morgen. This variable, which captures $52 \%$ of the combined variation across counties in the four underlying measures of compensation payments, is standardized to possess a mean of zero and a standard deviation of one in each of the regression samples considered by our cross-sectional analysis.

Enrollment rate 1864. The total number of enrolled students across a county's public elementary schools (Öffentliche Elementarschulen), private elementary schools (Privat-Elementarschulen), public middle schools for boys or girls (Öffentliche Mittelschulen für Söhne oder Töchter), and private middle schools for boys or girls (Private Mittelschulen für Söhne oder Töchter) in 1864, divided by the county's population of children of recommended schooling age (6 to 14) in 1864, constructed using county-level data reported by the Königlichen Statistischen Bureau (1861-1934, vol. 10). ${ }^{55}$

Literacy rate 1871. The number of a county's inhabitants aged 10 and above that were able to read and write in 1871, divided by the county's population aged 10 and above in 1871, constructed using county-level data reported by the Königlichen Statistischen Bureau (1874).

Steam engines 1875. The total number of steam engines (Dampfmaschinen) across industrial establishments in a county in 1875, divided by the county's population (in thousands) in 1875, constructed using county-level data reported by the Königlichen Statistischen Bureau (1861-1934, vol. 40).

Motorized engines 1875. The total number of all types of motorized engines (Umtriebsmaschinen und Arbeitsmaschinen) across industrial establishments in a county in 1875, divided by the county's population (in thousands) in 1875, constructed using county-level data reported by the Königlichen Statistischen Bureau (1861-1934, vol. 40).

\section{A.2 Variables in the panel analysis}

Log emancipation cases. The logged average annual number of emancipation cases settled in a district during a given 5-year period in the 1850-1898 time horizon, constructed using annual district-level data for this time horizon reported by Meitzen (1868, vol. 6). ${ }^{56}$ The settled emancipation cases include those in which former service and duty payers (Dienst- und Agabenpflichtige, welche abgelöst haben) redeemed their lifetime servile duties under the Dissolution Ordinance of

\footnotetext{
${ }^{55}$ For a small number of counties in our sample, our measure of the enrollment rate in 1864 exceeds unity, reflecting the enrollment of students that are either residents of neighboring counties or above 14 years of age or both.

${ }^{56}$ Consistently with our cross-sectional analysis, we exclude the district of Stralsund (i.e., the former Swedish Pomerania) from our flexible panel analsyis, because the emancipation process in this district was influenced by radically different institutions.
} 
1821 (Ablösungsordnung) as well as cases of redemption under the Commutation Law of 1850. The time intervals considered are 1850-1854, 1855-1859, 1860-1864, . . , 1895-1898.

Water mills 1819. The number of water mills used for the grinding of grains into flour, grits, or pearl barley in a district in 1819, divided by the district's population (in thousands) in 1821 (the population census year closest to 1819), constructed by aggregating up county-level data reported by Mützell (1823-1825, vol. 6) to the district level. This variable is standardized to possess a mean of zero and a standard deviation of one across districts in the regression sample.

Initial population. The logged population of a district in the initial year of a given 5-year period in the 1850-1898 time horizon, constructed using district-level population census data reported by the Statistisches Bureau zu Berlin (1851-1855, various vols.) and the Königlichen Statistischen Bureau (1861-1934, various vols.) for various years of this time horizon (censuses were conducted, roughly, every 3 years until 1871 and every 5 years from 1875 onward). The variable employed is based on a log-linear interpolation of population observed at the district level across these various censuses. The time series extracted from the interpolation corresponds to the years 1850, 1855, $1860, \ldots, 1895$.

Lagged uprisings. The number of violent protests, each involving at least 20 participants, in a district during a given 5-year period in the 1845-1894 time horizon, constructed using data reported by Tilly (1990) on the location and timing of such protests. The time intervals considered are 1845-1849, 1850-1854, 1855-1859, . . , 1890-1894. 
TABle A.1: Descriptive statistics of variables in the cross-sectional analysis

\begin{tabular}{|c|c|c|c|c|c|}
\hline & Obs. & Mean & Std. dev. & Min. & Max. \\
\hline Serf emancipation 1821-48 & 261 & 0.06 & 0.07 & 0.00 & 0.52 \\
\hline Water mills 1819 & 261 & 1.23 & 0.77 & 0.00 & 3.78 \\
\hline Terrain slope & 261 & 0.66 & 0.64 & 0.08 & 3.90 \\
\hline Terrain slope ${ }^{2}$ & 261 & 0.84 & 1.92 & 0.01 & 15.17 \\
\hline Average temperature & 261 & 8.09 & 0.82 & 5.66 & 9.72 \\
\hline Average precipitation & 261 & 6.34 & 1.13 & 4.89 & 10.70 \\
\hline Distance to navigable river & 261 & 0.32 & 0.26 & 0.00 & 1.39 \\
\hline Soil suitability (cereals) & 261 & 4.20 & 0.75 & 1.63 & 6.28 \\
\hline Sandy soil (share) & 261 & 0.28 & 0.23 & 0.00 & 0.81 \\
\hline East Elbe (dummy) & 261 & 0.75 & 0.44 & 0.00 & 1.00 \\
\hline Population density 1816 & 261 & 0.10 & 0.06 & 0.02 & 0.42 \\
\hline Urbanization rate 1816 & 261 & 0.24 & 0.13 & 0.00 & 0.86 \\
\hline Family size 1849 & 261 & 5.09 & 0.32 & 4.08 & 5.88 \\
\hline Knight estates (share) & 261 & 1.25 & 1.11 & 0.00 & 7.46 \\
\hline Protestants 1816 (share) & 261 & 0.68 & 0.37 & 0.00 & 1.04 \\
\hline Other ethnic group 1861 (share) & 261 & 0.17 & 0.28 & 0.00 & 0.90 \\
\hline Partible inheritance law (dummy) & 261 & 0.12 & 0.33 & 0.00 & 1.00 \\
\hline Enrollment rate 1816 & 261 & 0.60 & 0.21 & 0.03 & 0.95 \\
\hline Servile duties (PCA) & 261 & 0.00 & 1.00 & -0.61 & 7.01 \\
\hline Road 1848 (dummy) & 261 & 0.75 & 0.43 & 0.00 & 1.00 \\
\hline Railway 1848 (dummy) & 261 & 0.31 & 0.46 & 0.00 & 1.00 \\
\hline Coalfield (dummy) & 261 & 0.08 & 0.27 & 0.00 & 1.00 \\
\hline Number of uprisings 1816-47 & 261 & 0.30 & 0.85 & 0.00 & 9.00 \\
\hline Crown and state domains (share) & 261 & 0.08 & 0.09 & 0.00 & 0.50 \\
\hline Kulm estates (share) & 261 & 0.04 & 0.13 & 0.00 & 0.90 \\
\hline Born outside county 1871 (share) & 261 & 0.21 & 0.07 & 0.05 & 0.52 \\
\hline Redemption costs (PCA) & 261 & 0.00 & 1.00 & -0.45 & 11.78 \\
\hline Enrollment rate 1864 & 261 & 0.75 & 0.11 & 0.44 & 1.20 \\
\hline Literacy rate 1871 & 261 & 0.61 & 0.12 & 0.26 & 0.75 \\
\hline Steam engines 1875 & 261 & 0.85 & 0.94 & 0.02 & 6.39 \\
\hline Motorized engines 1875 & 261 & 3.01 & 1.39 & 0.66 & 8.63 \\
\hline
\end{tabular}




\section{Appendix B Supplementary results}

TABLE B.1: Cross-sectional analysis-First-stage regressions

\begin{tabular}{|c|c|c|c|c|c|c|c|}
\hline \multirow{3}{*}{$\begin{array}{l}\text { Dependent variable: } \\
\text { Specification: } \\
\text { Estimation sample: }\end{array}$} & \multicolumn{7}{|c|}{ Water mills 1819} \\
\hline & \multicolumn{2}{|c|}{ Geographical controls } & \multicolumn{2}{|c|}{ Proximate controls } & \multicolumn{2}{|c|}{ Additional controls } & \multirow{2}{*}{$\frac{\text { Redemp. }}{\text { Full }}$} \\
\hline & Full & East Elbe & Full & East Elbe & Full & East Elbe & \\
\hline & $(1)$ & $(2)$ & $(3)$ & $(4)$ & $(5)$ & $(6)$ & $(7)$ \\
\hline & OLS & OLS & OLS & OLS & OLS & OLS & OLS \\
\hline \multirow[t]{2}{*}{ Terrain slope } & $2.746^{* * *}$ & $2.828^{* * *}$ & $2.559^{* * *}$ & $2.639 * * *$ & $2.567^{* * *}$ & $2.535^{* * *}$ & $2.697 * * *$ \\
\hline & $(0.341)$ & $(0.308)$ & $(0.343)$ & $(0.367)$ & $(0.381)$ & $(0.322)$ & $(0.333)$ \\
\hline \multirow[t]{2}{*}{ Terrain slope ${ }^{2}$} & $-0.466^{* * *}$ & $-0.466^{* * *}$ & $-0.412^{* * *}$ & $-0.412^{* * *}$ & $-0.415^{* * *}$ & $-0.379^{* * *}$ & $-0.460^{* * *}$ \\
\hline & $(0.125)$ & $(0.127)$ & $(0.119)$ & $(0.117)$ & $(0.125)$ & $(0.110)$ & $(0.123)$ \\
\hline \multirow[t]{2}{*}{ Average temperature } & $0.324^{* * *}$ & $0.540^{* * *}$ & $0.330^{* * *}$ & $0.518^{* * *}$ & $0.260^{*}$ & $0.521^{* * *}$ & $0.311^{* * *}$ \\
\hline & $(0.122)$ & $(0.144)$ & $(0.114)$ & $(0.119)$ & $(0.135)$ & $(0.140)$ & $(0.118)$ \\
\hline \multirow[t]{2}{*}{ Average precipitation } & -0.046 & $0.344^{*}$ & -0.075 & $0.267^{* *}$ & -0.112 & $0.216^{* *}$ & -0.051 \\
\hline & $(0.087)$ & $(0.178)$ & $(0.082)$ & $(0.114)$ & $(0.088)$ & $(0.089)$ & $(0.086)$ \\
\hline \multirow[t]{2}{*}{ Distance to navigable river } & $0.339 *$ & 0.231 & 0.150 & 0.058 & 0.163 & 0.107 & $0.350^{*}$ \\
\hline & $(0.201)$ & $(0.197)$ & $(0.181)$ & $(0.208)$ & $(0.162)$ & $(0.202)$ & $(0.204)$ \\
\hline \multirow[t]{2}{*}{ Soil suitability (cereals) } & $-0.227^{*}$ & -0.264 & $-0.204^{*}$ & -0.200 & -0.183 & $-0.234^{*}$ & $-0.218^{*}$ \\
\hline & $(0.124)$ & $(0.169)$ & $(0.117)$ & $(0.145)$ & $(0.130)$ & $(0.135)$ & $(0.129)$ \\
\hline \multirow[t]{2}{*}{ Sandy soil (share) } & $1.493^{* * *}$ & $1.609^{* * *}$ & $1.485^{* * *}$ & $1.650^{* * *}$ & $1.545^{* * *}$ & $1.745^{* * *}$ & $1.453^{* * *}$ \\
\hline & $(0.275)$ & $(0.279)$ & $(0.277)$ & $(0.293)$ & $(0.309)$ & $(0.300)$ & $(0.293)$ \\
\hline \multirow[t]{2}{*}{ East Elbe (dummy) } & $0.540^{* *}$ & & $0.443^{* *}$ & & $0.430^{* *}$ & & $0.557^{* *}$ \\
\hline & $(0.263)$ & & $(0.188)$ & & $(0.194)$ & & $(0.267)$ \\
\hline Proximate controls & No & No & Yes & Yes & Yes & Yes & No \\
\hline Additional controls & No & No & No & No & Yes & Yes & Yes \\
\hline Observations & 261 & 195 & 261 & 195 & 261 & 195 & 261 \\
\hline Adjusted $R^{2}$ & 0.52 & 0.52 & 0.59 & 0.61 & 0.60 & 0.63 & 0.52 \\
\hline Shea partial $R^{2}$ & 0.45 & 0.45 & 0.42 & 0.37 & 0.36 & 0.33 & 0.43 \\
\hline
\end{tabular}

Notes. The dependent variable is the number of water mills per 1,000 inhabitants in a county in 1819, standardized to possess a mean of zero and a standard deviation of one across counties in each regression sample. The explanatory variable of interest is the average slope of the terrain in a county as well as its quadratic term. These variables are excluded from the corresponding second-stage regressions presented in columns 9 and 11 of Table 1 , columns 10 and 12 of Table 2, columns 9 and 11 of Table 3, and column 4 of Table 4 . The Shea partial $R^{2}$ thus reflects the explanatory power of the quadratic form in terrain slope for the variation in the prevalence of water mills across counties in 1819, after partialling out the influence of covariates. Standard errors, clustered at the district level, are reported in parentheses. $* * *$ denotes statistical significance at the $1 \%$ level, ** at the $5 \%$ level, and $*$ at the $10 \%$ level. 
TABLE B.2: Cross-sectional analysis - Excluding provinces from the estimation sample

\begin{tabular}{|c|c|c|c|c|c|c|c|}
\hline \multirow{2}{*}{$\begin{array}{l}\text { Dependent variable: } \\
\text { Excluded province name: }\end{array}$} & \multicolumn{7}{|c|}{ Serf emancipation 1821-48 } \\
\hline & Prussia & Posen & Silesia & Pomer. & Branden. & Saxony & Westph. \\
\hline & $(1)$ & $(2)$ & $(3)$ & $(4)$ & $(5)$ & $(6)$ & $(7)$ \\
\hline & 2SLS & 2SLS & 2SLS & 2SLS & 2SLS & 2SLS & 2SLS \\
\hline \multirow[t]{2}{*}{ Water mills 1819} & $0.189^{*}$ & $0.212^{* * *}$ & $0.201^{* *}$ & $0.174^{* *}$ & $0.255^{* * *}$ & $0.179^{* * *}$ & $0.309^{* * *}$ \\
\hline & $(0.102)$ & $(0.074)$ & $(0.094)$ & $(0.074)$ & $(0.076)$ & $(0.066)$ & $(0.091)$ \\
\hline Geographical controls & Yes & Yes & Yes & Yes & Yes & Yes & Yes \\
\hline Other proximate controls & Yes & Yes & Yes & Yes & Yes & Yes & Yes \\
\hline Observations & 207 & 235 & 204 & 239 & 231 & 223 & 227 \\
\hline Adjusted $R^{2}$ & 0.38 & 0.43 & 0.44 & 0.43 & 0.42 & 0.36 & 0.43 \\
\hline Kleibergen-Paap $F$ statistic & 34.30 & 49.07 & 52.66 & 50.07 & 52.25 & 57.30 & 94.86 \\
\hline
\end{tabular}

Notes. The dependent variable is the total number of serf emancipation cases settled in a county (under the 1821 ordinance) as of 1848, expressed as a fraction of the rural population of the county in 1816 (net of the population in small peasant landholdings). The main explanatory variable is the number of water mills per 1,000 inhabitants in a county in 1819. Both variables are standardized to possess zero means and unit standard deviations in each regression sample. See Appendix A and the discussion in Section 4 for additional details on all variables. In all columns, a quadratic formulation in terrain slope is employed as an excluded instrument for the number of water mills per 1,000 inhabitants in 1819. The abbreviated province names are Pomerania, Brandenburg, and Westphalia. Standard errors, clustered at the district level, are reported in parentheses. ${ }^{* * *}$ denotes statistical significance at the $1 \%$ level, ${ }^{* *}$ at the $5 \%$ level, and $*$ at the $10 \%$ level.

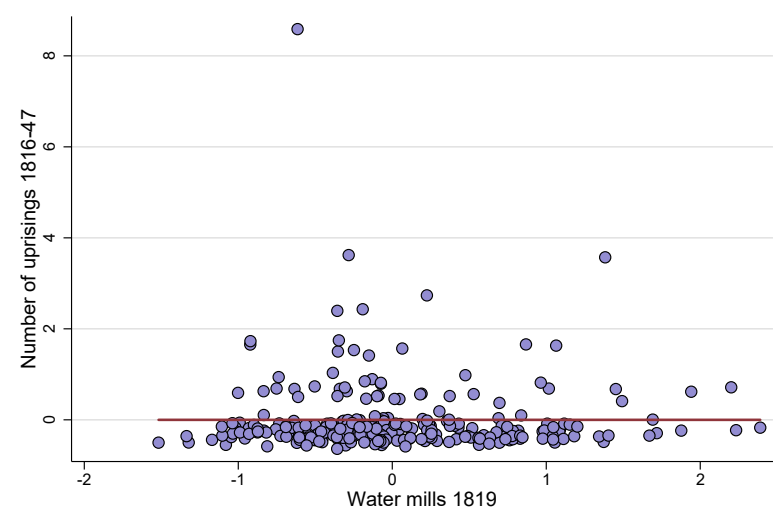

Slope coeff. (S.E.) $=0.000(0.041) ;$ Partial R2 $=0.00$; Obs. $=261$

(a) Elite capital-ownership and social uprisings

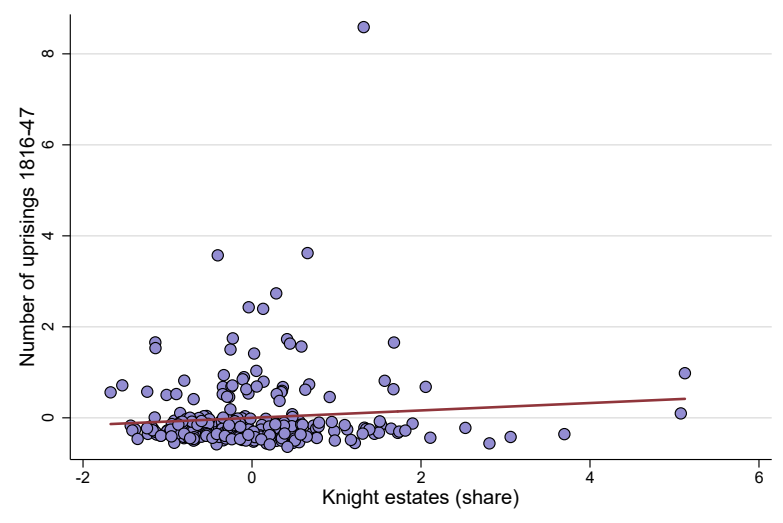

Slope coeff. $($ S.E. $)=0.081$ (0.039); Partial R2 $=0.01$; Obs. $=261$

(b) Elite landownership and social uprisings

Figure B.1: Degree of asset ownership by the elites and the threat of mass revolts

Notes. The scatter plots in this figure illustrate the absence of any systematic relationship across Prussian counties between the degree of either early capital-ownership (panel (a)) or landownership (panel (b)) by the elites, on the one hand, and the threat of mass revolts, as proxied by the number of social uprisings in a county during the 1816-1847 time horizon, on the other. In panel (a), the degree of early capital-ownership by the elites in a county is proxied by the number of water mills per 1,000 inhabitants in the county in 1819. In panel (b), the degree of landownership by the elites in a county is proxied by the share of all landholdings in the county that were classified as knight (noble) estates. The evidence presented in this figure thus supports the argument that counties in which the elites may have owned more assets did not necessarily face a higher or lower threat of mass revolts, and as such, this mechanism was not salient in the decision of the elites to accelerate or delay the de facto emancipation of their serfs. Both plots depict relationships that account for heterogeneity across counties in potentially confounding geographical factors. See the discussion in the main text and Appendix A for additional details. 


\section{Appendix C Legislative variation in de jure serf emancipation}

According to the historical evidence, as of the late eighteenth century, serfdom across Prussia was being practiced at varying levels of intensity, depending on the customary obligations of the peasants and the strength of their land tenure rights, and such variation was indeed prevalent even at the village level (see, e.g., Bowman, 1980; Harnisch, 1984; Pierenkemper and Tilly, 2004; Cinnirella and Hornung, 2016a). As such, the issue of de facto serf emancipation notwithstanding, the Prussian agrarian reforms of the early nineteenth century needed to enact different regulations for the de jure emancipation of different categories of the enserfed population. In addition, the political origin of these de jure reforms varied across regions of Prussia, depending on whether a region belonged to territories that were not ceded to France at the Second Treaty of Tilsit in 1807 (e.g., the provinces of Brandenburg, Pomerania, East and West Prussia, and Silesia) versus territories that were annexed or regained by Prussia following the Congress of Vienna in 1815 (e.g., the provinces of Posen, Rhineland, Saxony, Swedish Pomerania, and Westphalia). This appendix itemizes the idiosyncrasies associated with the de jure serf emancipation process throughout Prussia in the first half of the nineteenth century.

In regions belonging to territories that were not ceded to France at the Second Treaty of Tilsit in 1807, de jure serf emancipation was implemented in several stages between 1799 and 1850, with each stage pertaining to a different category of the peasantry as per their extant land tenure rights and the nature of their customary obligations to the nobility.

- Peasants residing on royal domains gained freedom from personal subjection in 1799. Their servile dues were commutated into leases either in money or in kind until 1806. Secure property rights to landownership were transferred to these peasants in 1808, and there was no de jure redemption process associated with their emancipation.

- Peasants residing on noble estates and holding weak (non-hereditary) rights to land tenure gained freedom from personal subjection in 1810, under the October Edict of 1807. Secure property rights to landownership as well as redemption of lifetime servile dues could be obtained de jure by these peasants under terms of the Regulation Edict of 1811 and the Declaration of 1816, at the cost of between one-third and two-thirds of their existing land parcels.

- Peasants residing on noble estates and holding strong (hereditary) rights to land tenure gained freedom from personal subjection in 1810, under the October Edict of 1807. Their lifetime servile dues could be de jure redeemed under the terms of the Dissolution Ordinance of 1821, at 25 times the equivalent annual cost of these duties. In the province of Silesia, however, regulation for the redemption of lifetime servile dues was implemented only in 1823 .

- Peasants that were engaged in only manual servile duties (nichtspannfähige Nahrungen) to the nobility, due to the fact that they resided on small land parcels that did not permit any 
agriculture of sufficient scale, gained freedom from personal subjection in 1810, under the October Edict of 1807. Their lifetime servile duties, however, could only be de jure redeemed under the terms of the Commutation Law of 1850, at 25 times the equivalent annual cost of these duties.

In regions belonging to territories that were annexed or regained by Prussia following the Congress of Vienna in 1815, de jure serf emancipation was generally triggered by external political factors, but in many cases, the rehabilitated Prussian nobility exerted significant influence on the de facto emancipation process, much like they did in other regions of Prussia that never came under Napoleonic influence in the period between 1807 and 1815.

- The territory of South Prussia (i.e., the Grand Duchy of Posen, the regions of Kulm and Michelau, and the city of Thorn) was annexed by the French in 1807 (as part of the Duchy of Warsaw) and thus came under the influence of the Code Napoléon. Following its repossession by Prussia at the Congress of Vienna in 1815, the General State Laws for the Prussian States (Allgemeines Landrecht für die Preußischen Staaten) were reestablished in this territory in 1817. Despite temporarily coming under the influence of the Napoleonic code, the process of de facto peasant emancipation made little progress in this region until after its repossession by Prussia. An 1823 Edict specified that peasants in this region could de jure redeem their lifetime servile duties under terms similar to the Dissolution Edict of 1821; i.e., at 25 times the equivalent annual cost of these duties.

- Peasants in Rhineland gained freedom from personal subjection in 1794, under the Code Napoléon. According to legislation passed in 1798, their lifetime servile dues could be de jure redeemed at 15 times the equivalent annual cost of these duties, and redeemability was further clarified by legislation in 1804. Following Prussian annexation, the French legislation remained in place in Rhineland, which is therefore excluded from our empirical analysis.

- Peasants in the former Electorate of Saxony (i.e., the Prussian districts of Merseburg and Erfurt) did not come under the de jure influence of French legislation. They gained freedom from personal subjection under Prussian legislation in 1819, and their lifetime servile dues were declared to be de jure redeemable under the terms of the Dissolution Ordinance of 1821, at 25 times the equivalent annual cost of these duties.

- Peasants in the former Swedish Pomerania (i.e., Prussian district of Stralsund) were de jure emancipated under agrarian reforms enacted by the Swedish Crown in 1806. From a legislative perspective, this district continued to maintain an exceptional position after Prussian annexation, and we therefore exclude it from our empirical analysis.

- Peasants in the former Kingdom of Westphalia (i.e., the Prussian province of Westphalia and the district of Magdeburg) gained freedom from personal subjection in 1808, under the Code Napoléon. According to legislation passed in 1809, their lifetime servile dues could be 
de jure redeemed at 25 times the equivalent annual cost of these duties. The Westphalian nobility, however, successfully blocked the legislation, and redeemability was only clarified in 1825. Thus, although the French legislation remained in place in Westphalia following Prussian annexation, the significant influence of the elites on the de facto peasant emancipation process made the Westphalian experience akin to those of the Prussian regions that were not temporarily ceded to France. 